\title{
False teeth: conodont-vertebrate phylogenetic relationships revisited
}

\author{
SUSan TURNER \\ Monash University Geosciences, Box 28E, Victoria 3800, \\ and Queensland Museum, Geosciences Annex, \\ 122 Gerler Road, Hendra, Queensland 4011 (Australia) \\ sue.turner@qm.qld.gov.au \\ Carole J. BURROW \\ Queensland Museum, Geosciences Annex, \\ 122 Gerler Road, Hendra, Queensland 4011 (Australia) \\ carole.burrow@gmail.com \\ Hans-Peter SCHULTZE \\ Natural History Museum, The University of Kansas, \\ 1345 Jayhawk Blvd., Lawrence, Kansas 66046-7561 (USA) \\ hp1937@ku.edu
}

Alain BLIECK

Université de Lille 1, Sciences de la Terre, FRE 3298 du CNRS Géosystèmes, F-59655 Villeneuve d'Ascq cedex (France) alain.blieck@univ-lille1.fr

Wolf-Ernst REIF† Eberhard-Karls-Universität, Institut für Geowissenschaften, Sigwartstraße 10, D-72076 Tübingen (Germany)

Carl B. REXROAD Indiana Geological Survey, 611 North Walnut Grove, Bloomington, Indiana 47405-2208 (USA)

Pierre BULTYNCK Department of Paleontology, Royal Belgian Institute of Natural Sciences, Vautier street 29, B-1000 Brussels (Belgium)

Godfrey S. NOWLAN Geological Survey of Canada, 3303 - 33rd Street NW, Calgary, Alberta, T2L 2A7 (Canada)

Turner S., Burrow C. J., Schultze H.-P., Blieck A., Reif W.-E.†, Rexroad C. B., Bultynck P. \& Nowlan G. S. 2010. - False teeth: conodont-vertebrate phylogenetic relationships revisited. Geodiversitas 32 (4): 545-594. 


\author{
KEY WORDS \\ Chordata, \\ Craniata, \\ conodont animals/ \\ elements, \\ character coding, \\ cladistic analysis, \\ palaeo-histology.
}

MOTS CLÉS

Chordata,

Craniata, animal-conodonte, codage des caractères, analyse cladistique, paléohistologie.

\begin{abstract}
An evidence-based reassessment of the phylogenetic relationships of conodonts shows that they are not "stem" gnathostomes, nor vertebrates, and not even craniates. A significant group of conodont workers have proposed or accepted a craniate designation for the conodont animal, an interpretation that is increasingly becoming established as accepted "fact". Against this prevailing trend, our conclusion is based on a revised analysis of traditional morphological features of both discrete conodont elements and apparatuses, histological investigation and a revised cladistic analysis modifying that used in the keystone publication promoted as proof of the hypothesis that conodonts are vertebrates. Our study suggests that conodonts possibly were not even chordates but demonstration of this is beyond the scope of this paper. To summarize, in conodonts there is low cephalization; presence of simple $\mathrm{V}$-shaped trunk musculature and unique large-crystal albid material in the elements; lack of a dermal skeleton including characteristic vertebrate hard tissues of bone, dentine and enamel; lack of odontodes with bone of attachment and a unique pulp system; lack of segmentally-arranged paraxial elements and dermal elements in median fins, all of which supports neither a vertebrate nor a craniate relationship for conodonts.
\end{abstract}

\section{RÉSUMÉ}

Des pseudo-dents: une réévaluation des relations phylogénétiques des conodontes et des vertébrés.

Une réévaluation des relations phylogénétiques des conodontes est fondée sur de nouvelles preuves. Elle montre que les conodontes ne sont ni des gnathostomes-souches, ni des vertébrés, ni même des crâniates. Un groupe significatif de spécialistes des conodontes a proposé, ou accepté, que ces organismes soient considérés comme des crâniates, une interprétation qui est en train de s'installer en tant que fait avéré. Notre conclusion va à l'encontre de cette tendance; elle est fondée sur une révision des traits morphologiques traditionnels à la fois des éléments isolés et des assemblages de conodontes, sur les données histologiques et sur une analyse cladistique révisée, ce qui modifie les conclusions de la publication principale qui a promu l'hypothèse selon laquelle les conodontes seraient des vertébrés. Notre étude suggère même que les conodontes n'aient pas été des chordés, mais la démonstration de cette hypothèse va au-delà de l'objectif de cet article. En résumé, chez les conodontes, le degré de céphalisation est faible; la musculature du tronc a une forme simple en $\mathrm{V}$; les éléments isolés montrent un tissu blanc avec des cristaux de grande taille, uniques pour ce tissu; il n'y a pas de squelette dermique incluant les tissus durs caractéristiques des vertébrés tels que l'os, la dentine et l'émail; il n'y a pas d'odontodes avec leur os et leur système pulpaire unique; il n'y pas d'éléments paraxiaux disposés de façon segmentée sur le corps, ni d'éléments dermiques aux nageoires médianes. Tout cet ensemble de caractères ne permet pas d'argumenter des affinités entre conodontes et vertébrés ou crâniates.

This paper is dedicated to the memory of our colleague, Professor Dr Wolf-Ernst Reif (1945-2009), who died just after acceptance of this paper. 


\section{INTRODUCTION}

The zoological affinity of conodonts, small exclusively marine animals of the Palaeozoic to early Mesozoic eras, has been vigorously debated ever since their phosphatic parts (calcium phosphate or apatitic conodont "elements") were first described by Pander (1856). For example, Müller (1981) listed almost 50 publications for the period 1856-1975 that variously suggested affinity with ten different taxonomic entities, including such diverse groups as vertebrates, annelids and plants. Chinese terminology reflects this with 11 different words equivalent to higher taxa for conodonts (Wang Cheng-Yuan, pers. comm. to ST, 1984). Of the multitude of proposed conodont relationships, Sweet (1988: 170-184) easily dismissed most, including strong evidence against any affinity with myxinoids (hagfishes) and even questioned the wisdom of a chordate relationship. Sweet (1988: 172, 173) discussed but provided no refutation for Tillier \& Cuif's (1986) claim that conodonts might be related to aplacophoran molluscs (but see Briggs et al. 1987), where they noted similarities between the two, having discovered calcium phosphate in the teeth and mandibles of one aplacophoran taxon. Calcium phosphate of course is not limited to conodonts (or vertebrates) but is found in several "invertebrate" taxa, such as in phyllocarids, nemertean stylets, some brachiopod shells, and also likely in the radular teeth of some chitons (Watabe 1990), and so Tillier \& Cuif's (1986) conclusions should be regarded as based on rather simplistic comparisons. Sweet (1988) concluded his analysis of possible affinities of the conodont organism with the suggestion that they could probably best be assigned to a separate phylum and were the result of yet another experiment in evolution that eventually became extinct. Here, we wish to continue the debate because we do not accept the increasingly prevailing paradigm that conodonts are vertebrates.

In referring to "conodonts" here we concentrate on only the euconodonts (= conodonts s.s.) or "complex" conodonts, as did e.g., Donoghue \& Aldridge (2001), Donoghue et al. (2000, 2008), and others, who claim that conodonts are vertebrates (see below) and restrict their hypothesis of conodont interrelationships to euconodonts. The relationships of the latter to other conodont groups (protoconodonts, paraconodonts) are still controversial (see references in Reif 2006). However, all conodont groups need to be considered in the context of their possible relationship to vertebrates if the conodont groups are closely related. Szaniawski (1983) interpreted protoconodonts as close relatives of chaetognaths reiterating this view in 1987 but then stressing that the evolutionary link between proto- and para-conodonts remains to be conclusively established. In 2002 he provided evidence for the protoconodont origin of chaetognaths. On the other hand, on the basis of well-preserved material from the Upper Cambrian of Sweden, Szaniawski \& Bengtson (1993) made a strong case for a close evolutionary link between para- and euconodonts. Müller \& Hinz-Schallreuter (1998) considered all three groups together, and noted a diversity of histological structures: the earliest supposed euconodont Cambropustula Müller \& Hinz, 1991 from the lower Upper Cambrian, for instance, lacks "white matter" (= albid tissue, an essentially opaque formless tissue "characterized by voids, which may be interlamellar spaces, or concentrations of small, densely packed, irregularly shaped cellules" [Lindström \& Ziegler 1971]), supposedly an evolutionary novelty within conodonts s.s. (Table 1); they considered the protoconodonts to be "ancestors" of paraconodonts. Others consider that paraconodonts and euconodonts is a totally artificial separation of a biologic continuum (Nicoll, pers. comm. 2009); the only real distinction between the two is the absence of white matter in the former. Both groups have complex apparatus structures that are similar in related species either side of the albid tissue divide. Nevertheless, Donoghue \& Aldridge (2001) maintained the separation of the three groups when considering conodont relationships to vertebrates. The problem then is how to reconcile e.g., Szaniawski \& Bengtson's (1993) and Müller \& Hinz-Schallreuter's (1998) hypotheses of euconodont phylogenetic relationships with Donoghue \& Aldridge's (2001: fig. 6.4) and Smith et al.'s (2001: fig. 5.5) hypotheses. Even with these contradicting views, to test their methodology we follow here Donoghue \& Aldridge's (2001) claim 
TABLE 1. - Comparison of terminologies (homologies) employed for different hard tissues of the conodont element by principal sources and a selection of papers cited. 1, Gross 1954, 1957, 1960; Müller \& Nogami 1971; Müller 1981; Schultze 1996; Reif 2006; 2, Briggs 1992; Sansom et al. 1992, 1994; Aldridge et al. 1993; Aldridge \& Purnell 1996; Smith et al. 1996, 2001; Samson 1996; Janvier 1997; Donoghue 1998, 2001; Donoghue et al. 1998, 2000, 2006; Donoghue \& Sansom 2002; Aldridge \& Briggs 2009; In bold: first use of terms.

\begin{tabular}{|c|c|c|c|}
\hline $\begin{array}{l}\text { Conodont } \\
\text { author }\end{array}$ & Crown tissue & "White matter" & Basal filling \\
\hline Pander 1856 & $\begin{array}{l}\text { konzentrische Lamellen } \\
\text { (concentric lamellae) }\end{array}$ & $\begin{array}{l}\text { kleine Zellen oder Höhlen } \\
\text { (with small cells or bubbles) }\end{array}$ & $\begin{array}{l}\text { hohl, Pulpa (hollow, pulp } \\
\text { cavity) }\end{array}$ \\
\hline Branson \& Mehl 1933 & & & $\begin{array}{l}\text { bony (no structure of ordi- } \\
\text { nary bone) }\end{array}$ \\
\hline Hass 1941 & lamellae & $\begin{array}{l}\text { cellular or cancellate struc- } \\
\text { ture }\end{array}$ & hollow \\
\hline Gross 1954,1957 & Lamellen (lamellae) & Scheinpulpa (pseudo pulp) & Basisfüllung (basal filling) \\
\hline Gross 1960 & Lamellen (lamellae) & $\begin{array}{l}\text { durch Bläschenbildung } \\
\text { getrübter Teil (part cloudy } \\
\text { by formation of bubbles) }\end{array}$ & $\begin{array}{l}\text { dicke Lamellen in Richtung } \\
\text { der Lamellen der Krone } \\
\text { (thick lamellae in line with } \\
\text { those of the crown) }\end{array}$ \\
\hline $\begin{array}{l}\text { Schmidt in Schmidt \& } \\
\quad \text { Müller } 1964\end{array}$ & Schmelz (enamel) & - & Dentin (dentine) \\
\hline Lindström 1964 & lamellae & $\begin{array}{l}\text { white matter with small } \\
\text { irregular cells }\end{array}$ & lamellae \\
\hline Lindström \& Ziegler 1971 & & albid & \\
\hline Barnes et al. 1973 & hyal & & \\
\hline $\begin{array}{l}\text { Müller \& Nogami 1971; } \\
\text { Müller } 1981\end{array}$ & growth lamellae & white matter & $\begin{array}{l}\text { growth lamellae in continua- } \\
\text { tion with those of the crown }\end{array}$ \\
\hline Lindström \& Ziegler 1981 & concentric lamellae & recrystallized with holes & $\begin{array}{l}\text { lamellae in continuation with } \\
\text { crown lamellae }\end{array}$ \\
\hline $\begin{array}{l}\text { "German" school } 1 \\
\text { Barskov et al. } 1982\end{array}$ & lamellar tissue & white matter & $\begin{array}{l}\text { different tissues } \\
\text { spongy bone }\end{array}$ \\
\hline Aldridge et al. 1986 & $\begin{array}{l}\text { hyaline lamellae, crystallites } \\
\text { parallel to direction of growth }\end{array}$ & & $\begin{array}{l}\text { Lamellae not always in con- } \\
\text { tinuation with those of the } \\
\text { crown }\end{array}$ \\
\hline Sweet 1988 & lamellae of hyaline & recrystallisation of hyaline & $\begin{array}{l}\text { lamellae continuous } \\
\text { with hyaline lamellae }\end{array}$ \\
\hline Wright 1990b & $\begin{array}{l}\text { lamellae with crystallites paral- } \\
\text { lel to direction of growth }\end{array}$ & $\begin{array}{l}\text { finely crystalline with holes } \\
\text { of }>1.0 \mu \mathrm{m} \text { diameter }\end{array}$ & \\
\hline Dzik 1986, 2000 & $\begin{array}{l}\text { enamel: large elongated crys- } \\
\text { tallites of apatite }\end{array}$ & not bone & $\begin{array}{l}\text { isometric apatite crystallites, } \\
\text { dentine }\end{array}$ \\
\hline $\begin{array}{l}\text { Szaniawski 1987; Sza- } \\
\text { niawski \& Bengtson } 1993\end{array}$ & lamellae & & two layers of lamellae \\
\hline Hall 1990 & $\begin{array}{l}\text { elongate, prismatic and short, } \\
\text { platy crystallites }\end{array}$ & & $\begin{array}{l}\text { amorphous, cryptocrystal- } \\
\text { line masses }\end{array}$ \\
\hline "British school" 2 & enamel & $\begin{array}{l}\text { cellular bone or kind of } \\
\text { enamel tissue }\end{array}$ & $\begin{array}{l}\text { dentine (mesodentine, } \\
\text { lamellar-to-spheritic tubu- } \\
\text { lar or atubular), or globular } \\
\text { cartilage }\end{array}$ \\
\hline $\begin{array}{l}\text { Kemp \& Nicoll 1995, } \\
\text { 1996; Kemp 2002b }\end{array}$ & $\begin{array}{l}\text { contains collagen therefore not } \\
\text { enamel }\end{array}$ & $\begin{array}{l}\text { absence of collagen there- } \\
\text { fore not bone }\end{array}$ & similarity to cartilage \\
\hline $\begin{array}{l}\text { Donoghue 1998; } \\
\text { Donoghue et al. 2000; } \\
\text { Donoghue \& Aldridge } \\
2001\end{array}$ & enamel & $\begin{array}{l}\text { distinct conodont tissue; } \\
\text { developmentally } \\
\text { homologous to enamel; } \\
\text { cellular dermal bone }\end{array}$ & $\begin{array}{l}\text { dentine; globular calcified } \\
\text { cartilage or dentine }\end{array}$ \\
\hline Kemp 2002a & $\begin{array}{l}\text { large, flat, oblong crystals par- } \\
\text { allel to long axis of element }\end{array}$ & & \\
\hline Guo et al. 2005 & & & $\begin{array}{l}\text { tubular, atubular } \\
\text { and spherulitic dentine }\end{array}$ \\
\hline
\end{tabular}


TABLE 1. - Continuation.

\begin{tabular}{|c|c|c|c|}
\hline $\begin{array}{l}\text { Conodont } \\
\text { author }\end{array}$ & Crown tissue & "White matter" & Basal filling \\
\hline $\begin{array}{l}\text { Trotter et al. } 2007 \\
\text { Aldridge \& Briggs } 2009\end{array}$ & $\begin{array}{l}\text { elongate, well-aligned crystals } \\
\text { translucent hyaline of lamellae } \\
=\text { enamel }\end{array}$ & $\begin{array}{l}\text { extraordinarily large crystals } \\
\text { white matter }\end{array}$ & $\begin{array}{l}\text { opaque basal body - den- } \\
\text { tine with tubules + calci- } \\
\text { spheres }\end{array}$ \\
\hline $\begin{array}{l}\text { Dzik } 2009 \\
\text { this paper }\end{array}$ & $\begin{array}{l}\text { lamellin } \\
\text { hyaline not enamel }\end{array}$ & white matter not bone & not dentine \\
\hline
\end{tabular}

that euconodonts have to be considered separately when testing their relationship with vertebrates.

The discovery particularly of the Scottish (Early Carboniferous, Mississippian), South African (Late Ordovician) and also Early Silurian (one from Wisconsin) remains of whole and partial specimens showing soft tissues preserved with conodont elements towards the anterior end of an elongate animal (Fig. 1A, B), precipitated the interpretation of a chordate-like anatomy for conodonts (Smith et al. 1987; Aldridge \& Briggs 2009). Indeed, Aldridge et al. (e.g., 1986, 1993), Briggs (1992) and Sansom et al. (1992) went further, arguing that conodonts are vertebrates (but see discussion in Reif 2006; Blieck et al. 2009; Bultynck 2009 and here). This opinion became virtual dogma with the publication of an extensive evaluation of chordate and conodont characters by Donoghue et al. (2000), who provided a cladistic analysis where conodonts became "stem gnathostomes" (see also Donoghue et al. 2006). We disagree with their conclusion and find that, based on the physical evidence, it is doubtful that conodonts were craniates.

In the present paper we put forward our case stating the need for a refutation of Donoghue et al.'s (2000) hypothesis, listing evidence against a conodont-vertebrate relationship, incorporating this data in a cladistic analysis based on the matrix they used, discussing in more detail our reasons against vertebrate relationship, followed by our conclusions. We think equally that whether conodonts are or are not truly chordates is still an open question, but a demonstration of such would require a far larger cladistic analysis than is the object of this paper or recovery of conodont animals with more clearly preserved diagnostic structures.

\section{SYSTEMATIC NOMENCLATURAL NOTE}

We make here a brief point about the use of terminology such as "crown group" (CG), "stem group" (SG), "total group" (TG). Using the definition of Jefferies (1979), a CG is the smallest monophyletic group, or clade, to contain the last common ancestor of all extant members, and all of that ancestor's descendants; all organisms that are more closely related to this CG than to any other living group are referable to its SG (Hennig 1969, 1983). As living taxa are by definition in the CG, it follows that all members of its $S G$ are extinct, and thus that SGs only have fossil members. A CG plus its SG considered together then constitute the "total group". Accepting these definitions presupposes that a SG is perforce paraphyletic (e.g., Jefferies 1979; Donoghue 2005). [But note that discrepancies can appear in the literature such as in Donoghue et al.'s (2006: fig. 1) paper where Chondrichthyes are included in the SG Gnathostomes whereas Acanthodii are not even considered.]

Another problem is the use of the same name for the "total group" as for the "crown group" (e.g., gnathostomes, tetrapods, etc.). In the case of tetrapods, the TG Tetrapodomorpha Ahlberg, 1991 includes the SG fossil piscine sarcopterygians down to the next extant sister group, the dipnoans. The SG includes piscine and tetrapod-like sarcopterygians. The content of the CG Tetrapoda depends on the position of the extant forms in a phylogenetic tree (Laurin \& Anderson 2004). In contrast, in the case of gnathostomes, the TG called Gnathostomata by Donoghue et al. (2000) creates a problem, because the next extant taxon is the Petromyzontida; no name based on a phylogeny has been suggested. 
This TG Gnathostomata should then include as the SG most fossil "agnathans", and therefore forms that lack characteristic gnathostome jaws. The TG Gnathostomata is thus not different from what could be named "euvertebrates" in the following topology (myxinoid (lampreys + euvertebrates)) (see Fig. 6). We prefer to use an apomorphy-based definition of a TG Gnathostomata (Placodermi (Chondrichthyes (Acanthodii + Osteichthyes)) ), that is, vertebrates with jaws, and distinguish it from a CG Eugnathostomata. The CG Eugnathostomata (Chondrichthyes (Acanthodii + Osteichthyes)) would include all extant gnathostomes and their fossil relatives, but not their fossil sister group Placodermi.

\section{"BRITISH SCHOOL" CONCEPTS OF CONODONTS AND VERTEBRATES}

Discovery by British palaeontologists (Briggs et al. 1983) of reasonably complete and partial conodontbearing animal specimens preserved with conodont elements distorted from life position but still in the head region (Fig. 1A, B), opened a new door on the interpretation of biological affinity because for the first time there was a "real conodont animal". The ten specimens from the Lower Carboniferous Granton Shrimp-Bed, Edinburgh (Clarkson [1985: 5] thought that the original "looked like a small lamprey"), combined with Silurian specimens from Wisconsin (Smith et al. 1987) and the more than 100 complete apparatuses, some in partial bodies, from the Upper Ordovician Cedarberg Formation in South Africa (Aldridge \& Briggs 2009), formed an early, and highly variable cohort of diverse biological information to assimilate into a single conodont animal model. As noted by others (e.g., Briggs et al. 1983: 3; Sweet 1988: 28-32; Conway
Morris 1989: 138; Bultynck 2009), the preservation is moderate, and interpretation of structures remains open to discussion (see e.g., Fig. 1C, E-H). The "British School" of conodont study that claims that conodonts are vertebrates mainly emanates from the work of R. A. Aldridge and his students at Leicester University (Aldridge \& Briggs 2009); several within this group have begun to class the elements as "microvertebrate" remains (e.g., in the British Micropalaeontological Society literature), a designation with which we also disagree based on the characters discussed below.

Despite widespread scientific challenges (e.g., Kemp \& Nicoll 1995, 1996; Schultze 1996; Kemp 2002a, b; Turner et al. 2004; Reif 2006; see e.g., Fig. 2) to such opinions and interpretations, conodonts continue to be touted as vertebrates, and even as stem gnathostomes, in scientific publications (e.g., Donoghue et al. 2000, 2008; Purnell 2001; Holland \& Chen 2001; Sansom et al. 2001, 2005; Smith et al. 2001; Donoghue \& Sansom 2002; Janvier 2003, 2007a, 2008; Albanesi \& Bergström 2004; Donoghue \& Purnell 2005; Dzik 2009; Sire et al. 2009), and increasingly now in text- and other books both scholarly and semi-popular (e.g., Prothero 1998; Liem et al. 2001; Benton 2005), and on the all-pervading Internet. There has been an increasing acceptance that conodonts are vertebrates in recent scientific and "informed" popular literature (e.g., Mallatt \& Chen 2003; Hall 2005; Kuhn \& Barnes 2005; Guo et al. 2005; Janvier 2006, 2007a, 2008; see discussion by Blieck et al. 2009) and even on websites (Janvier 1997, 2001), with little or no acknowledgement of contrary arguments (e.g., Aldridge \& Briggs 2009). The mostly dogmatic promulgation and uninformed acceptance of the hypothesis that conodonts are vertebrates has also invaded the molecular biology/

FIG. 1. - Conodont animal fossils showing soft tissues preserved and a selection of hypothetical interpreted reconstructions (not to scale): A, conodont fossil, Clydagnathus? cf. cavusformis in lateral view (anterior to the left) from the Lower Carboniferous (Visean) Granton Shrimp Bed Lagerstätte, near Edinburgh, Scotland, after Aldridge et al. (1993: fig. 3; specimen RMS GY 1992.41.1); B-B", interpretative drawing of conodont animal modified from Aldridge et al. (1993), with highlighted conodont elements above the animal, Lower Carboniferous from Scotland, redrawn by Aldridge et al. (1993) after Briggs et al. (1983: fig. 2); B, part of IGSE 13821; B', assemblage from counterpart IGSE 13822; B", head region of IGSE 13821; C, interpretation of whole conodont animal based on Besselodus Aldridge, 1982 elements and Clydagnathus? cf. cavusformis body modified from Dzik (1986: fig. 4); D, interpretation of conodont restoration with external conodont element array on front of head and added (unsubstantiated) branchial openings (modified from figure by David Baines in Aldridge \& Briggs (2009: fig. 4.2); E, interpretative restoration of whole conodont animal modified from Pridmore et al. (1997: fig. 4B; note that Janvier's [2009] reconstruction is virtually identical to this one); $\mathbf{F}$, interpretation of whole conodont animal with large eyes and two hypophysial openings, modified from Donoghue et al. (2000: fig. 6D); G, interpretation of 


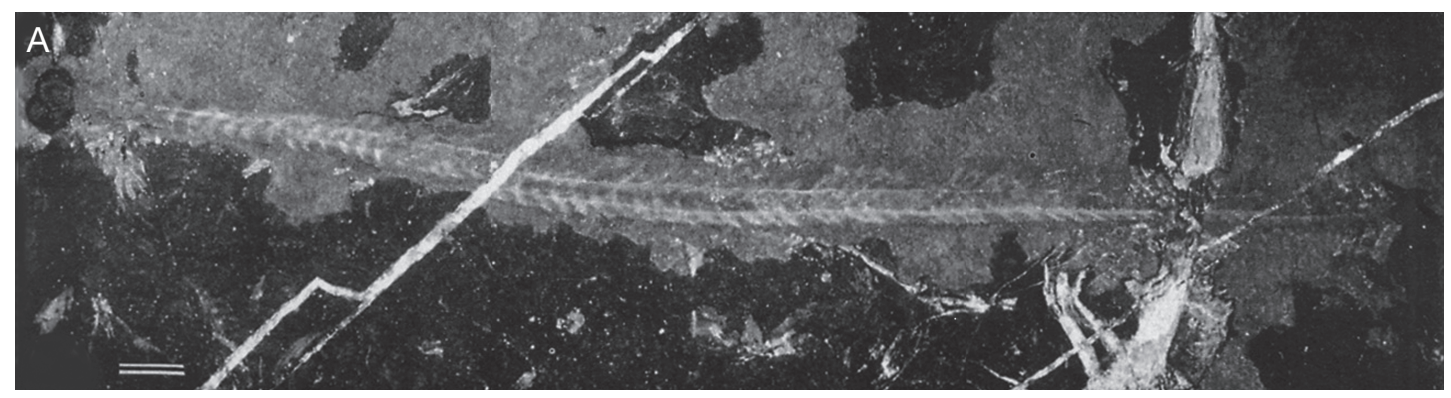

$\mathrm{B}$
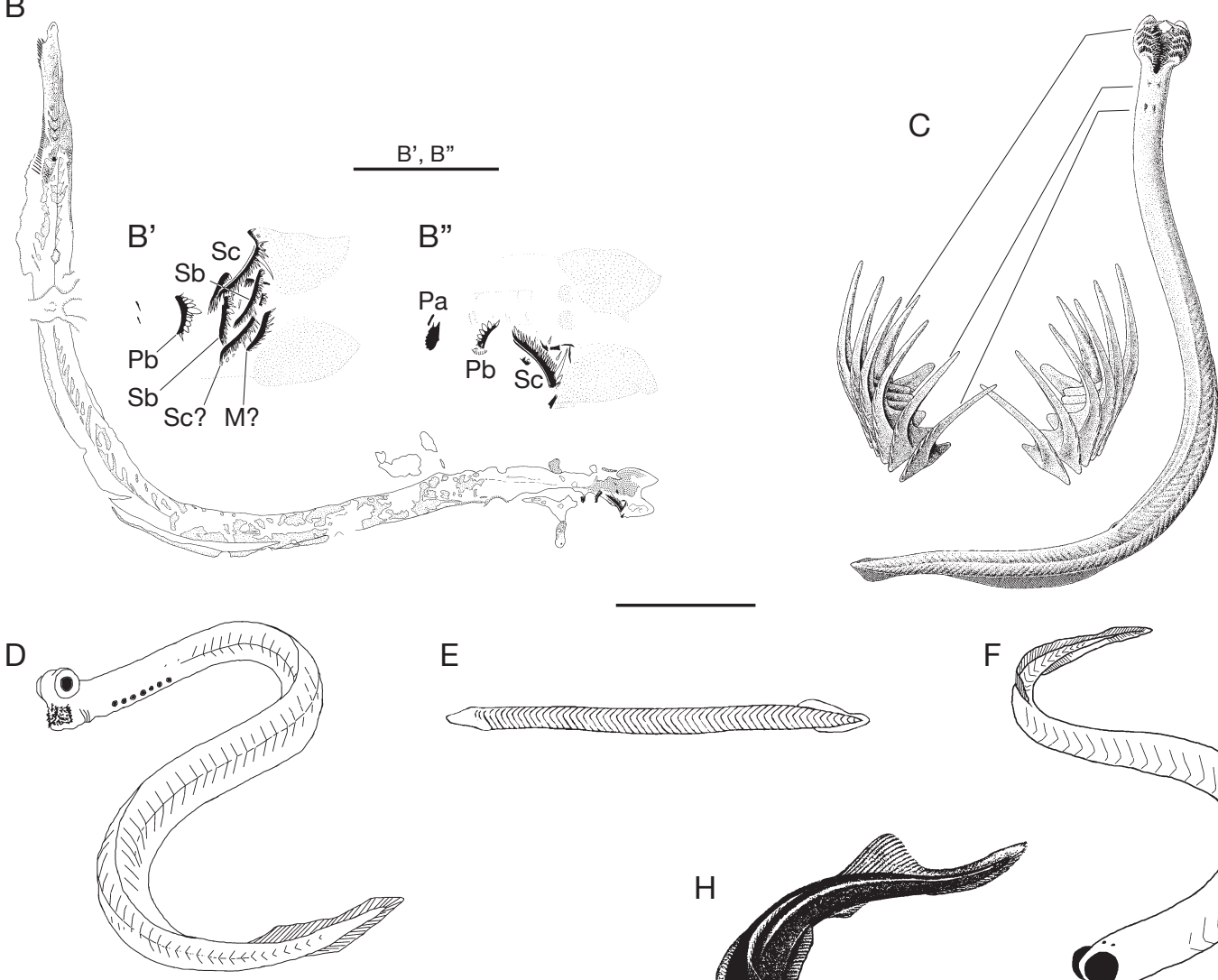

$\mathrm{E}$

G
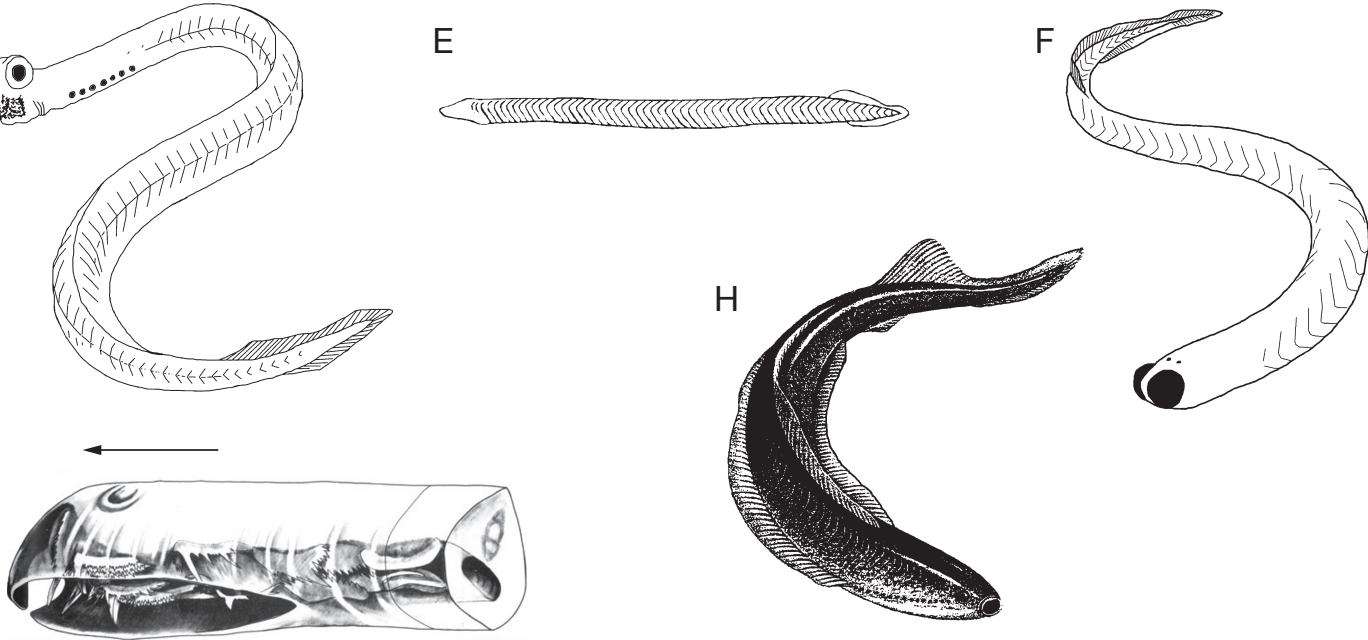

conodont animal head (arrow: anterior) using Polygnathus Hinde, 1879 elements by Nicoll (1995: text-fig. 1) (reproduced with permission from the author); $\mathbf{H}$, for comparison an interpretation of a "naked" lower vertebrate (mid-Palaeozoic agnathan) Jamoytius White, 1946, from a similar (Lower Silurian) Lagerstätte in Scotland, showing fin configuration, muscle blocks, and branchial openings (modified from a restoration by Colin Newman in Dixon et al. [1988: 26, figure]). IGSE, British Geological Survey, Murchison House Edinburgh, Scotland; RMS, now Museums of Scotland, Edinburgh, Scotland. Abbreviations: Pa, Pb, M, Sb, Sc: usual nomenclature for conodont elements. Scale bars: A, 2 mm; B', B", 2 mm; B, C-G: 5 mm. 
genomics literature (see e.g., Shimeld \& Holland 2000; Kawasaki et al. 2004), and conodonts are now accepted by many as more highly evolved than lampreys and hagfishes.

However, as noted by Hall (2005), not everyone accepts this view and if the work of the majority of conodont element workers is consulted (e.g., Walliser 1994; Nicoll 1995; Belka 2004), the claims would not have been as extreme. Most conodont workers have not become deeply embroiled in the debate because most are busy utilising conodont elements to solve geological problems and several, including R. D. Norby (pers. comm. to ST, 1997) think that leaving conodonts (for the time being) as "protochordates" provides a solution (but see now the arguments of Raineri [2006] and Reif [2006]).

\section{POSSIBLE FUNCTION OF SOME CONODONT APPARATUSES}

The conodonts (eu + para) first appear to have developed mineralized tissues to support the feeding apparatus in the late or early Late Cambrian. A trend in conodonts for an increase in morphologic complexity from coniform single denticles in the Late Cambrian to ramiform elements with multiple denticles on one or more processes to complex pectiniform blades and plates that can have surficial denticles and ridges can be observed. From the smooth surfaces of Cambrian forms, there developed ridges, grooves and surface striations or patterning. Some surfaces of some elements show regular to irregular reticulated surfaces that are thought to have been a reflection of the cell pattern of the tissue that covered the element and formed the growth layers of apatite that were accreted on the surface of the element with growth. All, or almost all, have morphologically differentiated apparatuses. Experimentation occurred in conodont apparatus architecture in the Late Cambrian and through much of the Ordovician. Particularly, Ordovician conodont apparatuses exhibit complexity with the $S$ vs P element split an early development. By the Silurian, apparatus architecture variety had become more limited and during the Devonian the pattern is almost stable remaining that way until the end-Triassic extinction of conodonts (e.g., Nicoll 1995).
So what are the possible functions of the conodont apparatus elements in the conodont animal? It is accepted by all sides of the discussion that the elements are located in the anterior or head region of the animal and that the apparatus elements were involved in the capture and ingestion of food. It is the mechanism of food capture and ingestion that is in question. It is also generally agreed that the morphological variation observed in the elements of any given apparatus suggests that the different parts served different functions.

Although there exists one notational location scheme for septimembrate apparatuses (Sweet 1981) that can be used for the major part of euconodont taxa, there is no unique typical conodont apparatus structure. The apparatus generally consists of 15 elements of 7 element types (septimembrate) but many geologically younger apparatuses, especially of Triassic age, have 15 elements of 8 element types (octimembrate). In the later example one of the element types, which in the early to mid Palaeozoic had been represented by two identical element pairs, have differentiated into two morphologically discrete element types. Some apparatuses consist of only 4 P elements (Polyplacognathidae, see Sweet 1988: 71).

Conodont apparatuses are generally composed of three basic types of elements that have three possible distinct functions. The anteriorly, and transversely oriented, M elements served to keep large material/ particles out of the food stream and protect the more fragile $S$ elements. The $S$ elements followed and, presumably covered by ciliated tissues, collected the food particles. Lastly are the P elements and these could do quite different jobs depending on their morphology. If just $S$ and $P$ elements are considered, there are a number of different types of conodont animals that must have had very different feeding strategies: coniform - coniform apparatuses (Teridontus, Drepanodus, Drepanoistodus); coniform - ramiform apparatuses (no known taxa); coniform - pectiniform apparatuses (Jumudontus, Pelekysnathus, Icriodus); ramiform - ramiform apparatuses (Erraticodon, Cordylodus); ramiform - pectiniform apparatuses (Polygnathus, Ozarkodina) (for full tabulation see Nicoll 1992: Table 1). In those apparatuses with pectiniform P, such as Polygnathus 
A

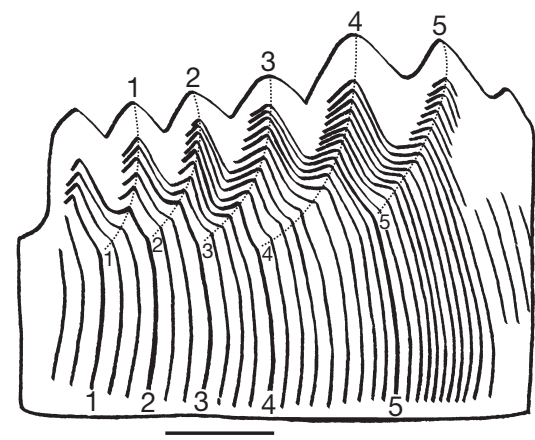

C

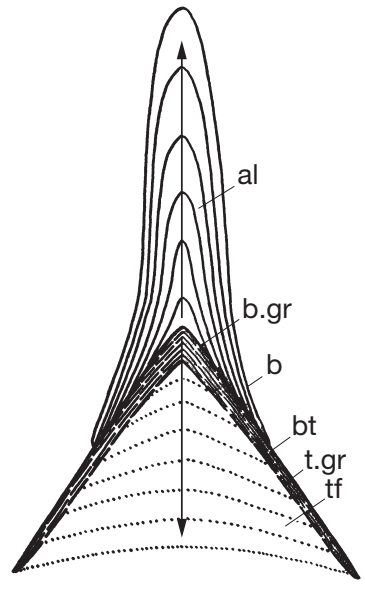

E

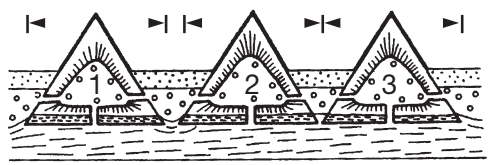

B B' brl
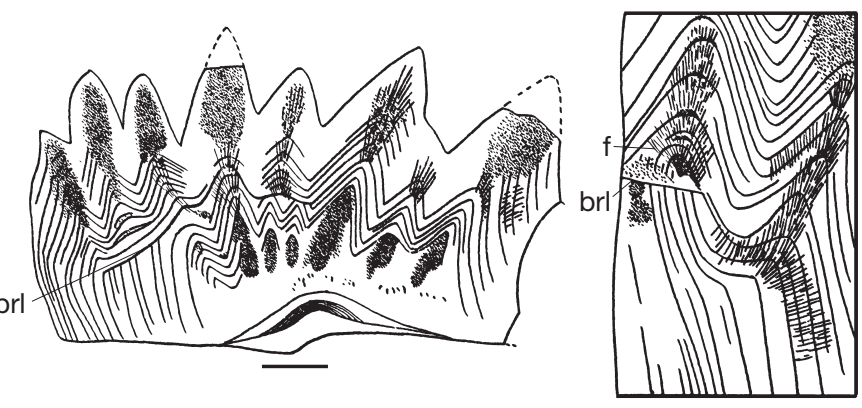

D
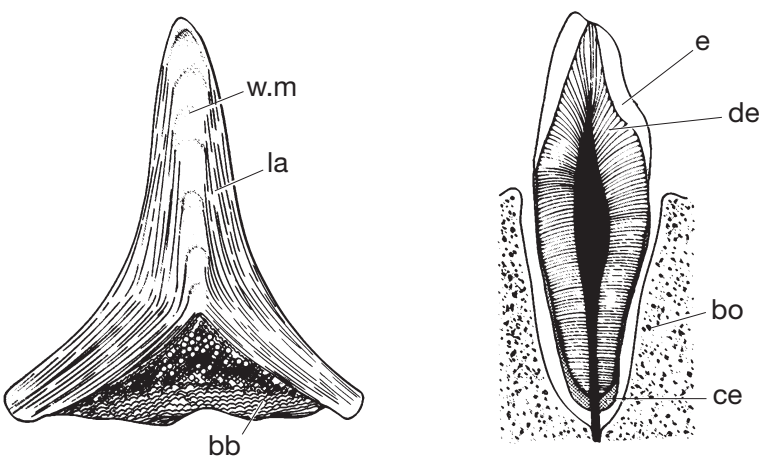

E'

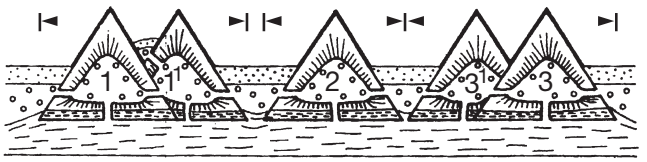

FIG. 2. - Histology of conodont element (showing continuous growth) vs vertebrate scale or tooth (odontode) formed in a papilla of mesenchymous cells: A, drawing of longitudinal section showing continuous growth with lateral additions and formation of serration of the conodont Gnathodus texanus Roundy, 1926 modified from Gross (1954: fig. 2, 1-5, subsequent addition of serrations) contra Donoghue (1998) Type 4 growth (reproduced in Reif 2006: fig. 4) where a basal body (or is it white matter?) apparently occurs in each serration (reproduced with permission from Senckenbergiana lethaea); B, B', longitudinal section through conodont "Ctenognathus" Pander, 1856 showing interrupted growth = "healing" (after Gross 1957: fig. 2D, F); C, schematic cross section to show continuous growth (arrows) of conodont element and basal filling (after Gross 1957: fig. 4); D, D', comparison of cross section of conodont element with osteichthyan (mammalian) tooth with pulp cavity (from Schultze 1996: fig. 2A, B; reproduced with permission from the author); E, E', formation of vertebrate odontodes in comparison to conodont growth in A. The odontode is formed by a papillary organ (with enamel organ, odontoblasts and osteoblasts in a single morphogenetic step). It cannot grow, but is enlarged instead by addition of a new odontode, that is formed by a new papillary organ resulting from a new interaction between ectoderm and mesenchyme (modified from Reif 2006: fig. 3a): thick line, enamel or enameloid; radiating lines, dentine with pulp cavity underneath; basal tissue, attachment bone $=$ cement with thin lines of deposition. Note the presence of pulp in vertebrate examples. Abbreviations: al, lamellar tissue; b, basis; bb, basal body; bo, bone; b.gr, basal groove; brl, interruption = break of growth in lamellar tissue; bt, basis cone; ce, cement; de, dentine; e, enamel; f, fine fibers; la, lamellar tissue; tf, inner basal filling; t.gr, boundary between the two kinds of filling of the basal groove; w.m, albid tissue or white matter. a, b, from original author figures. Scale bars: $0.1 \mathrm{~mm}$. 
linguiformis or Palmatolepis or Neogondolella, the elements were oriented laterally, opposed across the axial plane of the food chain (Nicoll 1987). In those apparatuses with coniform or ramiform $\mathrm{P}$ elements, they would have been oriented with the cusp tips pointing in the same direction (Nicoll 1995). Analyses of this sort demonstrated that many different conodont animals evolved with different feeding strategies.

Conodont elements are complex and consisted of two parts, a crown and an attachment structure (Fig. 2C). The histology of each of these is distinct (see below). The crown was that part of the element that was in contact with the external environment and thus the interactive part of the element, be it analogous to a tooth or a tissue-support structure. The attachment structure (attachment cone or plate or basal body; Fig. 2D) was connected to the inner hollow of the crown (or to its lower surface in planate elements) and to the muscle or ligament tissue of the conodont animal that controlled its movement. In most cases, only the crown tissue is recovered from the rock that contained the collected specimens, but attachment structures are common in some localities and can be especially common in some genera and element types (Nicoll 1995).

Here we do not accept the "British" reconstructions of the conodont animal (see e.g., Fig. 1D, F), and interpretations of the function of conodont apparatuses, i.e. elements functioning as teeth. As for an alternative view, Nicoll (1995) commented that the apparatus structure could have functioned as part of a microphagous filter-feeding structure and put the apparatus in an amphioxus-like body (Fig. 1G) to explain and interpret the anatomical relationships, claiming that there were three major and different working arrangements of conodont elements and that none could have served as a cutting function but that the Pa elements might have served in something of a crushing capacity (but see also below and Fig. 3C). The elements were at least partially, if not completely, covered by ciliated tissue and did not have to go through the difficultto-explain process of being "retracted" for new layers to be secreted. Nicoll (1995; and e.g., Kemp \& Nicoll 1995) strongly supported a non-vertebrate affinity, with which we concur. Crown growth was centrifugal (layers added increasing the size and complexity of the element with growth) and may or may not have occurred periodically (Zhang et al. 1997), which does not occur in vertebrate teeth.

Based on known specimens, we contend that a conodont apparatus should not be equated in any way with an array of biting, chewing, crushing/ grinding vertebrate teeth (cf. Reif 2006). In the case of some specific genera or species (Purnell \& von Bitter 1992; Purnell 1995b), such comparisons have been made but they should not be used for assigning conodonts to vertebrates. Others (e.g., Gedik \& Çapkinoglu 1996) claim a parasitic mode of life for conodonts, where by attaching themselves to the soft-tissue of a host-animal and sucking its fluids, the elements could show wear-traces, but those traces could heal during the time of attachment to the host animal, with major breaks visible later but as yet the morphogenetic evidence has not been presented.

A different point of view is given herein on the basis of the seximembrate apparatus of Polygnathus linguiformis linguiformis Hinde, 1879 (Fig. 3C). Two groups of elements can be recognized in this species on the basis of their location and their morphology. The anterior part of the apparatus consists of a set of ramiform elements ( $\mathrm{S}$ and $\mathrm{M}$ ) with mostly fine, delicate denticles, which were located in the anterior part of the buccal cavity (Nicoll 1985: fig. 10), i.e. inside the mouth. They are generally considered, also in other conodont genera, as a food-grasping/ filtering system (e.g., Nicoll 1985; Purnell 1993; Walliser 1994); again note the symmetry, which is opposed to any vertebrate array.

The second part of the apparatus consists of two pairs of pectiniform elements. A first pair of combshaped $\mathrm{Pb}$ elements, followed by a pair of platform elements $(\mathrm{Pa})$ that most likely were located in the posterior part of the buccal cavity in the pharynx, presumably close to the opening of the gut (Nicoll 1985). Grinding, crushing or cutting activities have been proposed for them (Nicoll 1985; cf. Purnell 1995a for Idiognathus Gunnell, 1931). The upper surface of the platform of the Pa element in Polygnathus linguiformis is characterized by a median, longitudinal crest (the carina) flanked on both sides by a longitudinal depression (the adcarinal troughs). 
A

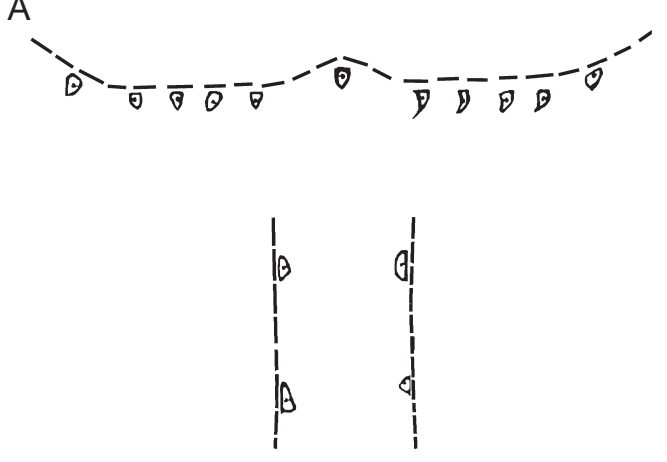

B
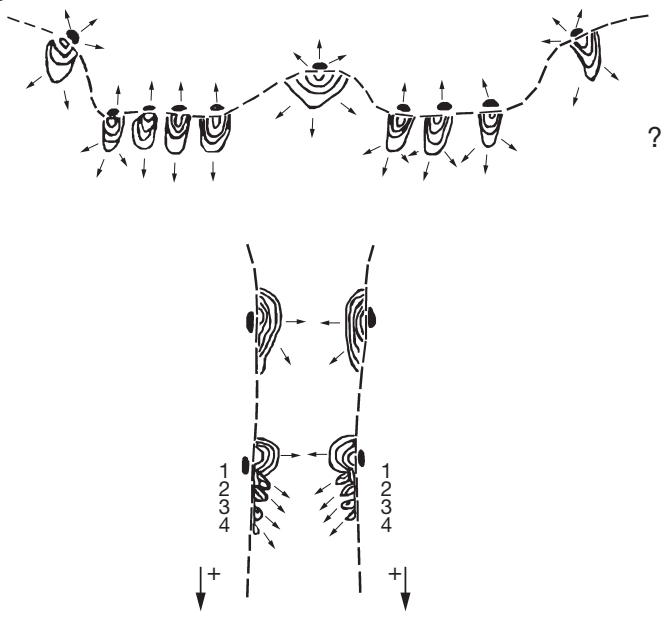
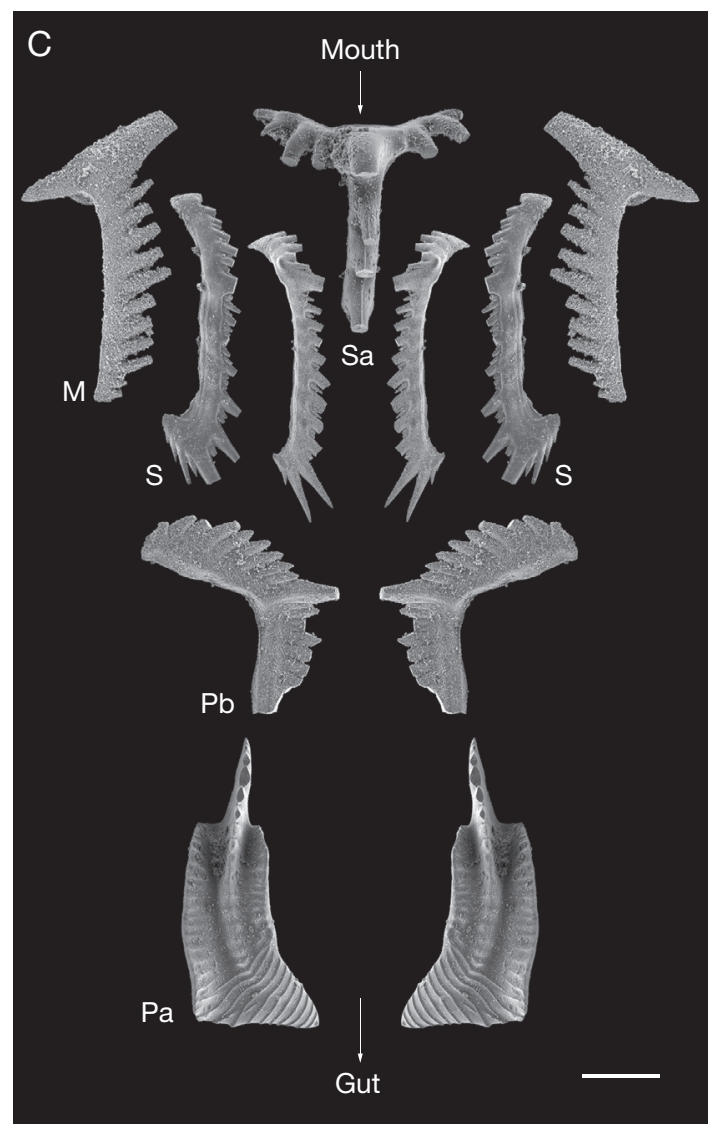

FIG. 3. - Morphogenesis of euconodont elements: A, hypothetical euconodont morphogenesis of apparatus, based on Clydagnathus cavusformis Rhodes, Austin \& Druce, 1969, Stage 1 - "shards" (cf. Reif 2006) of apparatus. There is no dental lamina, dental papilla, or tooth bud structure present (cf. Reif 1984); a pulp is absent; the tissues are not living but laid down like layers of inorganic crystals; repair is done by living tissue surrounding the element; B, Stage 2, continuous centrifugal growth with outer layers forming multicusps; whole apparatuses must form in one contemporaneous session to work, unlike vertebrate rotational dentitions (even in the most advanced mammals there are three separate cycles possible: milk, adult and wisdom teeth); C, Stage 3, the working complex in dorsal view, anterior to top; oesophagus to bottom: reconstructed seximembrate apparatus of Polygnathus linguiformis linguiformis Hinde, 1879 (assembled by PB, and see Sweet 1998: 99) based on elements from sample BT 18, S Morocco, Tafilalt, Lower Givetian Bou Tchrafine section (see Bultynck 1987). The location of the elements is based on the most generally accepted scheme. The elements are shown in such way that their outline and ornamentation can be clearly recognized; their orientation does not correspond to the original natural orientation in the apparatus. So, the $\mathbf{M}$ and $\mathbf{S}$ elements (except the $\mathbf{S a}$ ) and the $\mathbf{P b}$ element should be turned upward over an angle of $45^{\circ}$. The anterior and posterior processes of the $\mathbf{P b}$ element meet at an angle of about $130^{\circ}$, similar to the deflection of the posterior tongue of the $\mathbf{P a}$ element. The orientation of the $\mathbf{P}$ elements is a matter of discussion. The elements of the apparatus are deposited at the Institut royal des Sciences naturelles de Belgique, Brussels, under catalogue number I.R.Sc.N.B. no. b5177. Scale bar: $500 \mu \mathrm{m}$.

The platform ends in a tongue-like structure, deflected outwards and downwards (see Nicoll 1987: plate 5.3, figs 8-12). During life the element was covered by (epidermal) tissue, the cells of which could leave an imprint on the surface of the element (see Weddige 1989: fig. 14). The course and the height of the carina, the depth of the adcarinal troughs and the form and orientation of the posterior end of the platform are variable and diagnostic for species, not only in the genus Polygnathus Hinde, 1879. The morphology of this type of Pa element is not adapted for good occlusion between the right and 
left Pa elements [Note that contrarily good occlusion is necessary for the functioning of vertebrate teeth.] An alternative interpretation might be that contractions in the epidermal tissue bring food particles via the $\mathrm{Pb}$ elements to the Pa elements and these are then guided via the adcarinal troughs to the gut opening. The tongue-like posterior part of the Pa element might have assisted a swallowing movement at the opening.

Finally, it should be stressed that the architecture of at least some evolved multimembrate conodont apparatuses show no convincing similarities with tooth arrangements in the buccal cavity either of agnathans or primitive Gnathostomata and functioned in a completely different way.

\section{CHORDATE, CRANIATE, VERTEBRATE CHARACTERS}

The major phyla of the deuterostomes are the Echinodermata, Hemichordata (including the Pterobranchia, the Enteropneusta and the Graptolithina), and the Chordata. The latter traditionally includes the subphyla Tunicata. The term "protochordates" has commonly been applied to all these taxa except the Echinodermata and Craniata. The Echinodermata, "protochordates" and Craniata supposedly share in common the deuterostomate condition (at least in recent taxa) whereby the gastropore of the embryo becomes the anus of the adult, and which shows a modified trisegmental body plan; and most possess gill-slits and a central axial structure, a notochord that provides some skeletal support. However, this "situation" exemplifies the difficulty of the problem of comparing an echinoderm, an enteropneust or graptolite, and a chordate, a real difficulty as these organisms exhibit very different morphologies. In other words, this difficulty deals with deep nodes of a cladogram, when the phylogeny is built for such a general or basic systematic question, where defining homologous features is fundamental.

The Echinodermata are deuterostomes, and the carpoid echinoderms are considered by Jefferies (2001 and citations therein) and followers as closely related to craniates but few agree with his "calcichordate" hypothesis. Amongst the hemichordates, both the
Enteropneusta and the Pterobranchia show a tripartite body plan and the latter possess a single pair of gill slits. The body plan of the long-extinct graptolites is unknown. None of these minor phyla possesses any significant resemblance to the conodonts; it is amongst the Chordata and especially Craniata that certain resemblances have been claimed.

The phylum Chordata has been diagnosed by the presence of characters such as a notochord, a dorsal hollow nerve cord, pharyngeal gill slits, segmented muscle blocks (myomeres) (Fig. 4B-E), and a postanal tail. Of the modern members of the phylum, only the craniates possess a substantial fossil record because of the major preservational bias for apatitic hard tissues - bone, dentine and their possible precursors (for definitions of hard tissues and their development see Francillon-Vieillot et al. 1990). This lack of potentially basal chordate fossil material has proven a major obstacle in the search for chordate origins (cf. Blieck 1992). Indeed, Garstang (1928) based his theory of a paedomorphic origin solely on the embryology of extant chordates, and postulated that an organism similar to a tunicate or cephalochordate larva could have acquired sexual maturity without metamorphosing, thus providing a spring-board for the evolution of chordates and vertebrates.

The discovery of exceptionally preserved softbodied biotas in Konservat-Fossil-Lagerstätten has provided opportunities to examine and describe fossil lampreys and myxinoids from the mid-Palaeozoic (Janvier \& Lund 1983; Bardack 1997; Poplin et al. 2001; Gess et al. 2006), and also purported fossil chordates from the Cambrian. Widely varying interpretations have been proposed for relationships of soft-bodied Cambrian taxa to living groups. Emmonsaspis cambrensis (Walcott, 1890) from the Lower Cambrian of Vermont has been allied with the graptolites, chordates, arthropods, and frondlike organisms since its initial description (Conway Morris 1993a, b). Even the most widely accepted earliest chordate, Pikaia gracilens Walcott, 1911, from the Middle Cambrian Burgess Shale, was originally interpreted as a polychaete annelid, and has since been allied with the cephalochordates based on synapomorphies such as chevron-shaped myomeres and an anteriorly extending notochord 

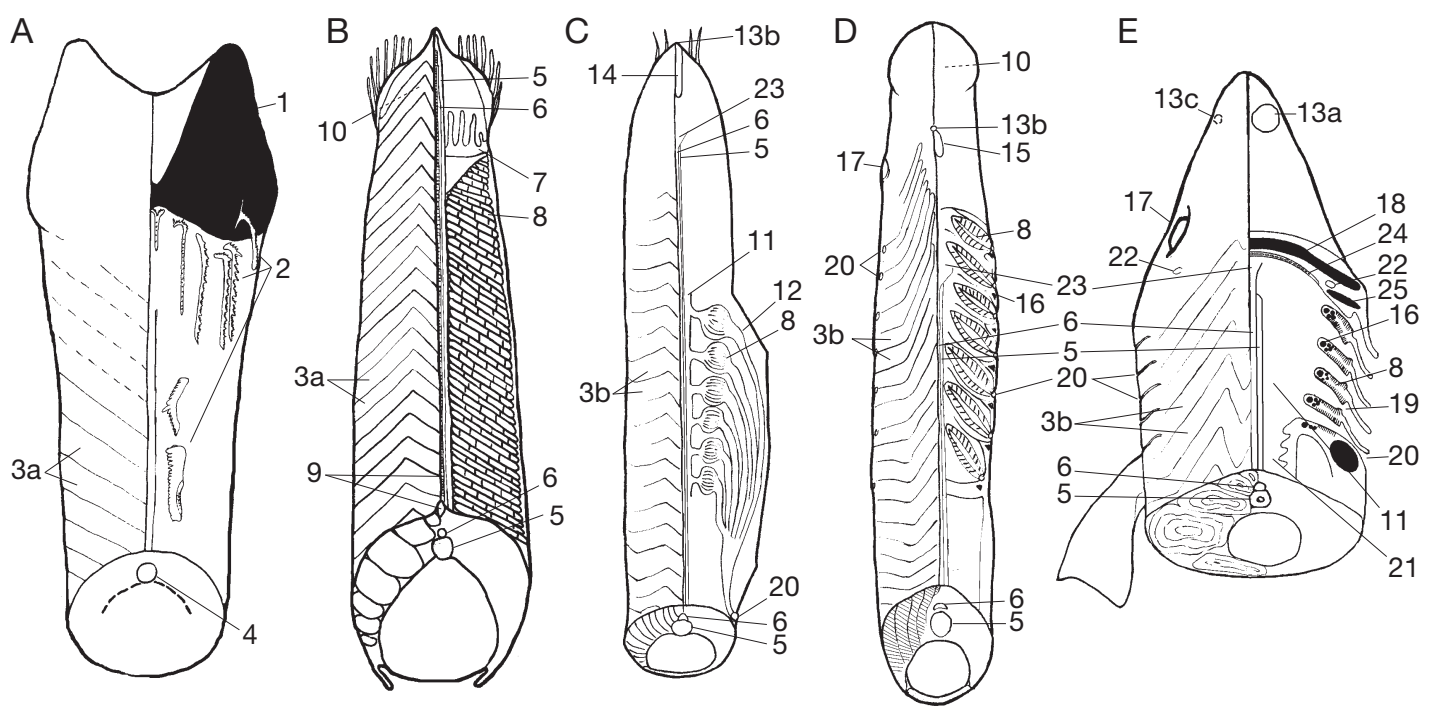

FIG. 4. - Schematic frontal and cross sections of anterior end of a conodont animal compared with a cephalochordate and selected chordates. The left side of the animals shows dorsal surface features and muscle segmentation and the right side is cut away to show internal features at the level of the branchial region (if present): A, generalized conodont showing the position of conodont elements (association of structures based on Briggs et al. 1983, which is still highly imaginative with little reality beyond the general shape: note the diametrically opposed symmetry of apparatus to any vertebrate); B, amphioxus Branchiostoma lanceolata (Pallas, 1774); note that the notochord reaches into an anterior extension, but not the neural cord and not the dorsal "fin" (see 9) (after Bracegirdle \& Miles 1978 and Parker \& Haswell 1921); C, hagfish Myxine glutinosa Linnaeus, 1758 (after Dean 1899 and Marinelli \& Strenger 1954); D, lamprey Lampetra fluviatilis (Linnaeus, 1758) (after Marinelli \& Strenger 1956: figs 6, 10, 17, 36, 42); E, shark Squalus sp. (frontal section after Liem et al. 2001: fig. 18-2C). 1, muscular "cone"; 2, conodont apparatus (after Aldridge 1987: fig. 1.3 and Norby 1976); 3a, V-shaped myomeres; 3b, W-shaped myomeres; 4, medial tube; 5, notochord; 6, nerve cord; 7, velum (oral hood); 8, gill; 9, fin-ray box; 10, mouth; 11, pharynx; 12, branchial duct; 13a, nasal sacs; 13b, nasohypophysial opening (NB: not 13 for both as in Donoghue et al. 2000); 13c, nares; 14, hypophysial duct; 15, hypophysial sac; 16, gill arch; 17, eye; 18, mandibular arch with odontodes (teeth); 19, gill chamber; 20, external gill slit; 21, oesophagus; 22, spiracle; 23, brain; 24, anterior margin of pharynx; 25, hyoid arch.

(Conway Morris 1998), despite the presence of two anterior tentacles unknown in cephalochordates, but recently has again been excluded (Janvier 2003). With its two tentacles, it looks more like Tullimonstrum gregarium Richardson, 1966 (Pennsylvanian, Mazon Creek, Illinois), which has variously been compared to annelids, arthropods and molluscs (see Beall 1991; Conway Morris 1991, 1993a; Dzik 2000).

Discovery of older material from the Lower Cambrian Chengjiang Formation of Yunnan has led to finds such as Yunnanozoon lividum Chen et al. 1995 and Cathaymyrus diadexus Shu, Conway Morris and Zhang, 1996 (Shu et al. 1996a), with differently coloured features and impressions interpreted as a notochord, muscle blocks, and gill slits comparable with the preservation of soft tissues in fossil lampreys and myxinoids (and we would argue that the structures look more like gills than anything seen in Mayomyzon Bardack \& Zangerl, 1968 from the Pennsylvanian of Illinois, USA). Yunnanozoon lividum has also been considered to be a hemichordate (Shu et al. 1996b), or the most basal chordate (Chen et al. 1999), with $C$. diadexus as only a junior synonym of Y. lividum (Chen \& Li, 1997). Still the search for chordate ancestors is anything but resolved. However, the deep dorsal body or fin of Yunnanozoon (M1 to M22 in Chen et al. 1995) does resemble the dorsal fin of the Permian cephalochordate from South Africa (Oelofsen \& Loock 1981). In addition, with other possible early craniates from the same locality, such as Myllokunmingia fengjiaoa Shu, Zhang \& Han, 1999 (= Haikouichthys ercaicunensis Luo, Hu \& Shu, 1999; see Shimeld \& Holland 2000: fig. 2) with gill pouches, the timing of chordate origins might be as early as Early Cambrian, or even Precambrian (Turner et al. 2004). As yet, however, there are no 
Cambrian complete, mineralized, conodont or vertebrate body fossils, which contrasts with the "Cambrian explosion" when so many mineralized "invertebrate" taxa appeared (calcitic, phosphatic, siliceous, etc.).

Of course, we know that for phylogeneticists the problem of origin of any taxon cannot be linked absolutely to time. This is primarily concerned with systematics. However, when considering that the earliest claimed vertebrates (craniates) are possibly Early Cambrian in age [i.e. accepting the Chinese ones discussed above], this is solely based upon the known fossil record, and can therefore be used as a test of the phylogenetic scheme adopted.

Returning to modern chordate groups, all known chordates possess asymmetrically-organized internal organs, which are linked to control by proteins encoded by genes expressed on the left side of all known vertebrate embryos (Boormann \& Shimeld 2002a, b). Raineri (2006), however, recently refuted the chordate affinities of the protochordates based on the development of their notochord and central nervous system on the ventral rather than dorsal side (indicating that they are gastroneuralians, bilateralia with ventral neural cord), the muscular structure of their notochord, and lack of attachment of the axial musculature to the notochord. This is not a new idea (Arendt \& Nübler-Jung 1994; Bergström 1996, 1997; Bergström et al. 1998) for the problem was already discussed in the 19th century. In any case, the definitive paper on chordate relationships based on whole-genome analyses of selected tunicates, a lancelet, and vertebrates (i.e. representatives of the three modern chordate groups) supported retention of cephalochordates in the deuterostomes, but basal to tunicates and chordates, with amphioxus (lancelets) as the most basal chordate (Putnam et al. 2008: fig. 2).

The craniates are characterized by presence of a neural crest, a notochord ventral to the neural cord (spinal cord) and additional characters connected with the brain (e.g., Janvier 2008). Reif (2006) reduced the chordates to craniates = hagfishes + vertebrates. Here we keep a conservative view of chordates with two basal groups, i.e. tunicates and cephalochordates, and a crown group, i.e. craniates including hagfishes and vertebrates.

\section{WHAT IS A VERTEBRATE?}

What, then, are the characters that define a vertebrate? To quote Raineri (2006: 271) "the dawn of the vertebrates came into being when the dorsal ectoderm was turned into neural tissue on mesendodermal induction"; or from Janvier (2003: 526), the diagnosis of the vertebrates is "based on two developmental characters [...] the presence of neural crests and epidermal placodes". The resulting physical characters unique to vertebrates include "odontogenic tissues of the dermal skeleton and the branchial skeleton" and the "formation of the major vertebrate sensory organs, such as the olfactory, optic and otic capsules, and the lateral line system". Following recent work on hagfish embryology by Ota et al. (2007), the neural crest character can be expanded to the presence of delaminating neural crest, previously thought to be a character of all vertebrates except hagfishes.

One of the sticking points in the debate for most people relates to what is a "true" vertebrate. Many conodont workers are using a very loose definition of what is a vertebrate compared to most vertebrate workers, backed up by the so-called "Total Group" Concept of Jefferies (Reif 2004 and see above). The debate can only continue when everyone involved agrees on the definition of a vertebrate (Janvier 2003; Reif 2006), and to promulgate understanding, this definition is communicated widely.

In general morphology, vertebrates possess a notochord, lying ventral to the central nervous system, at some stage in the life history, an extensive central nervous system, dermal placodes that develop into sense organs, the neural crest, and an exo- and endoskeleton. The primitive tripartite body plan is confined to the embryo and ontogeny provides a succession of new segments arising by subdivision of the second segment. Corresponding to this multiplication of segments are the muscular somites and the series of segmental gill slits. All possess a post-anal tail at some stage in their life history. In the development of their phosphatic hard tissues, vertebrates other than lampreys possess forms of dentine and bone (see further below). 
CONODONT ELEMENT HARD TISSUES

VS VERTEBRATE TISSUES

Conodont elements exhibit exceptionally diverse histological structure (Müller 1981; Hall 1990), and variation, caused by intrinsic factors as well as the effects of diagenesis on individual elements can result in differing fine structure for elements of the same or closely related taxa. Cordylodus Pander, 1856 elements from Ordovician deposits at Sukrimagu in Tallinn, Estonia have no trace of the thin high-organic layers described in elements of this genus by Szaniawski \& Bengtson (1993). The one Cordylodus specimen illustrated by Sansom et al. (1992) from the Lower Ordovician of Estonia reveals fewer details of the hard tissues in the element, although it does appear to have layers of hydroxyapatite arranged as radial crystals. Similar variation can be found in other genera of conodonts and in other parts of the conodont element. Elements of Chirognathus Branson \& Mehl, 1933, also from the Harding Sandstone, are described as having scalloped growth lamellae, intersected by parallel tubules and occasional calcospherites in the basal body, which Smith et al. (1995: 310, 311, fig. 3A-C) considered to be indicative of vertebrate dentine. Elements of the same taxon from the same deposit have also been described as having growth lamellae with undulations of diagenetic origin, and the histological appearance of this specimen is given no special phylogenetic significance (Müller 1981: fig. 21.4).

Here we discuss some of the interpretations of conodont hard tissues, and give examples of those in and outside the vertebrate paradigm. Table 1 shows different interpretations of the tissues of the conodont elements. One major problem is lack of training in histology, which leads to misunderstanding of hard tissues. The intention of Gross (1954, $1957,1960)$, a noted palaeohistologist, was to demonstrate how the conodont tissues differ from those of vertebrates (see Fig. 2A-C).

\section{Dentine}

We consider that dentine is a prime hard tissue denoting a vertebrate (e.g., Turner et al. 2004). Donoghue et al. $(2000,2006)$ considered conodont basal bodies to be formed of dentine, but the globular tissue they discuss cannot be homologous with vertebrate dentine, which grows centripetally (Gross 1954, 1957; Schultze 1996; Reif 2006; Fig. 2E), and is added basally not topically (Trotter et al. 2007). Even just considering the basal body structure, Carter \& Lutz (1990: pl. 25, fig. D) illustrated the calcitic, lathic Regular Simple Prismatic (RSP) outer shell layer of the bivalve mollusc Anomia simplex, which looks more like dentine than anything in conodonts. Additionally, Dong et al. (2005) studied the basal tissue structure in "the earliest euconodonts, presumed to be the most plesiomorphic" (Cambroistodus, Dasytodus, Granatodontus, Hirsutodontus, Proconodontus, and Teridontus) showing a wide spectrum of variation in fabric from atubular lamellar, lamellar with "multiple point nucleation sites", tubular to fibrous, none of which corresponds to dentine per se (see also Dzik 2009). Euconodont elements have no (pulp) cavity, hence not the slightest trace of blood and nerve supply (Fig. 2), nor any other sign that there was a living tissue such as dentine (Gross 1954; Schultze 1996; Reif 2006). This last point we consider most important. Interestingly, there seems to have been little research done on the development of the vertebrate odontode pulp system (pulp, pulp cavity) by molecular developmental biologists (e.g., Hall 2005).

Openings in the white matter of conodont elements are too small to have housed osteocytes (bone-forming cells) or odontoblasts (contra Sansom et al. 1992; Dzik 2009; see Schultze 1996). As noted above, the tissue material at the base (basal body) of the conodont element (when present, for generally the basal body is unknown, having been lost in most taxa in post-mortem taphonomic processes) does not have a structure consistent with any known (ortho)dentine (Kemp \& Nicoll 1996; Fig. 2C-E).

\section{Enamel}

Vertebrate enamel is a highly structured hard tissue, almost devoid of organic matter in the mature state, and containing small crystals of calcium hydroxyapatite (Carlson 1990; Warshawsky 1989). True enamel is found in sarcopterygians, but actinopterygians also possess enamel (ganoin) instead of the more usual collagen-based enameloid in chondrichthyans, 
also a highly organized material (Carlson 1990) but formed below the basal membrane in teeth (Reif 2006: figs 4F, 5C, D, H). Dipnoans (lungfish: Kemp 1992, 2003; Satchell et al. 2000; Kemp \& Barry 2006; Barry \& Kemp 2007), like other sarcopterygians (Schultze 1969; Smith 1989), are among those "advanced" fish (i.e. basal to tetrapods) having true enamel in the dentition. Enamel (ganoin) of a similar protoprismatic form in developing stages is also found in the scales of primitive fossil and living actinopterygians like Erpetoichthys calabaricus (Smith, 1865) (Zylberberg et al. 1997). In these fish taxa, the early enamel resembles the initial stages of enamel formation in mammals (Satchell et al. 2000), although, at least in lungfish, it develops into protoprisms with a unique crystalline structure (Kemp \& Barry 2006).

Thus, enamel in the dentition or scales of vertebrates (sarcopterygians and tetrapods), also arranged in layers but with a different morphogenesis (Reif 2006; see Fig. 2Db, E), has slender, elongate spicular crystals of calcium hydroxyapatite, perpendicular to and external to the basal membrane surface of the tooth or scale. The crystals are invariably arranged in specific ways, depending on the animal from which they came, and (despite Donoghue's 2001 doubt) are oriented perpendicular to the surface of the tooth or scale (e.g., Sander 2000). The close association of the enamel with a dentine-enamel junction is also a distinctive character of vertebrate enamel (Fig. 2E). When a complete series of wellpreserved sarcopterygian material covering developing and mature stages is examined, non-prismatic to prismatic enamel can be observed (Carlson 1990). In mammals, enamel prisms are highly ordered but patterns vary enormously among the different groups (e.g., Koenigswald 2000). In reptiles (Sander 1997, 2000) and amphibians, the enamel is less highly ordered.

Subsequent to the description of the hard tissue histology of conodont elements as exhibiting structures found in highly evolved vertebrates such as sharks and mammals (Sansom et al. 1992), conodont element fine structure was classified into three broad types, lamellar crown tissue, white matter, and basal tissue (Donoghue 1998; Donoghue \& Chauffe 1998). These authors considered lamellar crown, or hyaline, tissue to be homologous with vertebrate enamel, despite the large size of the component crystals (Donoghue 1998: 653), and the complete lack of any prismatic structure (Donoghue \& Chauffe 1998). Variation in orientation of the crystals among different conodont genera was also considered unimportant. The lamellar crown tissue was described (Donoghue 1998: 655, 658) as distinct and separate from the white matter with which it interdigitates (forming the centre of serrations in conodont elements, see Gross 1954). However, these three characters, large crystal size, close association with the lateral hard tissue or white matter (Schultze 1996), and the lack of prismatic structure in the conodont hyaline tissue (Fig. 2B) indicate that the latter in conodont elements is not homologous to vertebrate enamel (Table 1). Lack of equivalence of the two tissues is emphasized when the numerous conodont elements with longitudinally or obliquely arranged mineral crystals, such as in Panderodus Ethington, 1959, are taken into consideration.

Notwithstanding the claims that conodont animals are vertebrates and the elements are true vertebrate teeth, transmission (TEM) and scanning electron microscopy (SEM) has shown that the mineralized component of the hyaline tissue of two Ordovician conodont taxa known only from elements, Panderodus and Cordylodus, consists of large, flat, oblong crystals, arranged in layers that run parallel to the long axis of the element. Within the layers in Cordylodus, crystals of hyaline tissue are positioned across the layer, perpendicular to the surface of the element. In Panderodus, the crystals are arranged obliquely or in line with the layer. The hydroxyapatite crystals in conodont hyaline tissue are exceptionally large, with no trace of prisms, unlike fish protoprismatic enamel, or the highly organized prismatic enamel of mammals (e.g., Kemp 2002a; Trotter \& Eggins 2006; Trotter et al. 2007).

Light and scanning electron microscopy can provide conflicting evidence, even when the same taxon is used (Sansom et al. 1992; Szaniawski \& Bengtson 1993). Some analyses indicate that the hyaline tissue of conodont elements cannot be enamel because it consists of bipartite layers (e.g., one Triassic conodont illustrated by Zhang et al. [1997] shows it clearly and they makes a point of it), not found in any 
vertebrate enamel (Szaniawski \& Bengtson 1993). The hyaline tissue is certainly high in organic matter, possibly remains of collagen (although doubted by Aldridge \& Briggs 2009), also not a characteristic of vertebrate enamel (Kemp 1999, 2002a; Kemp \& Nicoll 1996; Trotter \& Eggins 2006).

\section{Bone, cartilage and other tissues}

Nevertheless, the hard tissues of conodont elements have been described as vertebrate, comparable to equivalent structures in sharks, other extinct fish and mammals (Barnes et al. 1973; Barskov et al. 1982; Sansom et al. 1992). The hyaline tissue of the element crown is described by them as radial crystallite enamel and the "albid tissue" (= white matter of others; Table 1) as bone with lamellae and osteocyte lacunae, the latter having canaliculi to house the cellular processes of the osteocytes. Depending on species, the single (rarely preserved but erroneously shown as multiple "growth cavities" in the histogenesis scheme of Donoghue 1998: fig. 9) basal body is alleged to include spheritic calcified cartilage, comparable to a similar tissue in sharks (Sansom et al. 1992) and in Eriptychius Walcott, 1892 from the Upper Ordovician Harding Sandstone (Smith et al. 1996), or mesodentine, as in certain younger fossil fish (Sansom et al. 1994; Donoghue 1998), or even lamellin (Dzik 2009). These comparisons based on superficial resemblances have been used to support the classification of conodonts among the vertebrates (Aldridge \& Purnell 1996) although, as we here emphasize, this determination is not universally accepted (e.g., Kemp \& Nicoll 1995; Kemp 2002a, b; Müller 1981; Schultze 1996; Walliser 1994; Table 1).

Similarly, the albid tissue cannot be bone because it contains no organic residues, and the spaces in the tissue in unaltered elements are too small to be osteocyte lacunae (Fåhraeus \& Fåhraeus-von Ree 1994; Kemp \& Nicoll 1995). True bone is mineralized and reacts in polarized light; Ca-phosphate is mineralized differently in enamel, dentine, bone and mineralized cartilage. The original work of Sansom et al. (1992) was based on material that can best be described as highly altered, so the identification of botryoidal mineralization in the basal body of Cordylodus elements as spheritic calcified cartilage can be understood. The structures described in the Cordylodus elements bear no resemblance to spheritic calcified cartilage in Recent elasmobranch material (e.g., Francillion-Viellot et al. 1990; Dean \& Summers 2006).

Contra the earlier work, Donoghue et al. (2006: 282) now disavow any bone in the conodont "oral skeleton". Thus, removing the conodonts from the equation, even Donoghue et al. (2006) state that "true" enamel is only found in CG osteichthyans. Comparison of the ultrastructure of non-prismatic hyaline tissue in conodont elements and the organized enamel of vertebrates provides little support for a close phylogenetic relationship between vertebrates and conodonts. Trotter \& Eggins (2006) and Trotter et al. (2007: 108) have recently shown that the large albid crystals of the crown tissue of a euconodont element are quite different from the fine crystalline tissue of dermal bone, dentine and enamel of vertebrates, contradicting specifically Sansom et al. (1992, 1994), Smith et al. (1996), Donoghue (1998), and Donoghue \& Aldridge (2001). The crystals of hydroxyapatite in conodont hyaline tissue are large, with no trace of a prismatic arrangement, unlike the protoprismatic enamel of fish teeth and scales, or the highly organized prismatic enamel of mammal teeth. In addition, crystal arrangement in conodont hyaline tissue varies widely among conodont taxa (Wright 1990). Crystal arrangements similar to those of fish enamel are found in higher vertebrates, but none resembles, in any respect, any of the crystalline arrangements to be found in the hyaline tissue of conodont elements. All those findings on conodont vs vertebrate mineralized tissues support the arguments of Kemp (2002a) and Reif (2006) who refuted the arguments of Donoghue et al. (2000, 2003, 2006, 2008).

\section{Other tissue characters}

Conodont elements lack the colour range and lustre seen in vertebrate microfossils (e.g., Ørvig 1973: fig. 3 and see cover of The Australian Geologist Newsletter $107,1998)$. This consistent difference also refutes the presence of dentine with tubules in conodonts as these structures allow vertebrate fossil remains to infuse colour from the surrounding matrix. The conodont and microvertebrate colour indices are 
therefore different although vertebrate material does respond to thermal changes, but with a different (as yet uncalibrated) set of gradations (Turner 1994b). Regarding co-occurring conodont elements and early vertebrate remains, another difference can be advocated. In her study of Silurian microvertebrate remains and conodonts from the Baltic Basin and from central Asia (Tuva, NW Mongolia, South Siberia), Z. Zigaite (pers. comm. to AB) found that thelodont tissues retain less $18 \mathrm{O}$ than conodonts, an outcome which gives a higher recalculated palaeotemperature of sea water based on dentinous thelodont scales than conodont elements, which is probably because of a major difference in the ultrastructure of the respective mineralized tissues. This trend is increased when a stronger diagenetic alteration occurred, as in Tuva where most vertebrate microremains (thelodonts, mongolepids, acanthodians) are whitish and give much too high palaeotemperatures (of $c .50^{\circ} \mathrm{C}$ !).

Turner \& Blieck (1995) also considered conodont vs vertebrate micro-ornaments. Although the imprinting of external cells of overlying soft tissue on (dermal) hard parts is possible in many animals, the patterns seen in many conodont elements are different from those in vertebrate scales and teeth. These impressions were used as an argument for conodonts being vertebrates by Simonetta et al. (1999) but, as Reif (2006: 418) also showed, cell impressions are not exclusive to the surface of enamel nor can they be used as conclusive identification for enamel in conodonts. For comparison, Märss (2006) reviewed micro-ornaments in a wide variety of vertebrate scales with surficial enamel, enameloid, and dentine.

To summarize, there is so much evidence that conodont elements are not and have nothing to do with teeth that it is not even a question of whether they can be vertebrate. There is no pulp cavity in highly evolved conodonts, even if the basal body could be regarded as such in early conodonts (Müller \& Hinz-Schallreuter [1998] reckoned that the latter appeared as an evolutionary novelty within the euconodonts). Schultze (1996), Reif (2006), and others cited here, have shown that the hard tissues in euconodont elements do not have the morphogenetic history or structure to be interpreted as vertebrate, let alone teeth.

\section{RELATIONSHIPS OF CONODONTS BASED ON MORPHOLOGY OF CRANIATES AND "PROTOCHORDATES"}

As noted above, cephalochordates and craniates share a well-developed system of somites; nevertheless, Raineri (2006) considered this a convergence and excluded cephalochordates from the deuterostomes. Thus, in considering cephalochordates, fossil possibilities include Yunnanozoon (= Haikouella), the Permian Palaeobranchiostoma Oelofsen \& Loock, 1981, and the mid-Cambrian Burgess Shale Pikaia Walcott, 1911, which is still not fully accepted. This discussion of cephalochordate structure is therefore based mainly on a handful of Recent species belonging to two families (at most) and to a single order, exemplified by Branchiostoma lanceolata (Costa 1834) (Fig. 4B).

Craniates and Branchiostoma share a number of features, some of which have a functional origin in locomotion. Chief among these are the skeletal, muscular and nervous elements, specifically the notochord (Branchiostoma lives in the sediment with the notochord on the ventral side, therefore the discussion as to where "dorsal" and "ventral" is in Branchiostoma, see above), the hollow dorsal nerve cord, and the organisation of the musculature into folded segmental somitic blocks. In both groups during ontogeny each of the three gill-slits on each side folds into a $U$ shape, with the fold dorsal in position (Fig. 4). Conodonts and craniates differ in the following major ways.

\section{Cephalization and eyes}

Protochordates in general, including cephalochordates, show little sign of cephalization. Accepting the interpretation of the Cambrian Yunnanozoon from China as a cephalochordate indicates that the cephalization in early cephalochordates (Mallatt \& Chen 2003) was further developed than in the extant Branchiostoma. By contrast, the higher craniates show perhaps the greatest level of cephalization of any animals, involving as many as nine segments (Balfour 1877). It should be noted, however, that cephalization is not restricted to a single monophyletic group. In any mobile animal, that part which meets the environment first - the 
anterior end, is likely to develop a concentration of sense organs. The pressures towards cephalization are thus present in all mobile groups, viz., shrimps and worms, snails, frogs, dogs, etc. All Recent craniates, including hagfishes and lampreys (Fig. 4), have a "new head" comprising organs produced by delamination and migration of neural crest cells; this process has only recently been demonstrated in hagfishes (Ota et al. 2007).

Conodont body fossils show little sign of cephalization except for the possible anterior internal oral/ branchial feeding apparatus (Fig. 4A; see discussion in Nicoll 1995) but no nasal or hypophysial openings are known, unlike vertebrates (cf. Fig. 1F, $\mathrm{H})$. Again, as emphasized by others (e.g., Walliser 1994, and pers. comm. 2009), the symmetry and operational movement of the conodont elements within the apparatus is at $90^{\circ}$ to that of any vertebrate tooth array or branchial system, thus again mitigating against their being either true vertebrate teeth or vertebrate per se. The level of cephalization in this regard is not higher than the oral hood of Branchiostoma (Fig. 4B). Briggs et al. (1983) identified the large paired dark stains at the anterior end of the Granton conodont Clydagnathus? cf. cavusformis (C. windsorensis (Globensky, 1967)) as eyes (Fig. 1A, D, F). Subsequently, Gabbott et al. (1995) and Purnell (1995b) interpreted muscle fibres in a similar position on the giant conodont Promissum pulchrum Kovács-Endrödy, 1987 from the Soom Shale (Cedarberg Formation, latest Ordovician [latest Hirnantian]-earliest Silurian [earliest Rhuddanian], Table Mountains, South Africa; Vandenbroucke et al. 2009) as extrinsic eye muscles. These structures, preserved as semicircular or somewhat rhombic bands/sheets (Donoghue et al. 2000: fig. 4G), are unlike those of any known vertebrate eye, appearing to be the remnants of muscular halfrings or cones rather than discrete eye muscles (see also Reif 2006). Trunk and tail myomeres (muscle blocks) of conodonts are V-shaped (Fig. 1A) and not W-shaped as in all craniates including hagfish and lamprey (see e.g., Pridmore et al. 1997: fig. 4). The V-shape of the myomeres in the South African conodonts are highlighted by post-mortem shrinkage, but by comparison the purported eye muscles appear to be broad sheets. Even the shape of the "eye" stains of Clydagnathus? are unusual, being preserved as flattened cones with the apices meeting medially (Aldridge 1987: fig. 1.9B), and thus not comparable to vertebrate sclerotic capsules or eyes and eye muscles. Are these paired structures actually lateral, or could they have been dorsal and ventral? When Briggs (2003) noted that "The toothlike elements [...] are consistently preserved to one side of the head", he presumably inferred the orientation from the position of the "eyes'. Even if, unlikely as it seems, these structures were eyes or eyespots, the tunicate Larvacea and larval Ascidiacea also possess eyespots.

This feature, then, is inadequate for distinguishing between craniate and protochordate affinities for conodonts. For comparison, Janvier \& Arsenault (2007) distinguished lateral and median stains without identifying the lateral stains as eyes at the correct position even in the indubitable craniate Euphanerops Woodward, 1900.

\section{Anterior end of notochord}

Adult Branchiostoma have a notochord that extends into the preoral region, to the anterior tip of the animal (Fig. 4B). In all other protochordates and in all craniates the notochord (when present) is confined to that posterior portion of the body behind the hypophysis or its homologue (Huxley 1858; Carlisle 1953). This is also the anterior termination of the notochord in embryonic Branchiostoma, and the anterior extension develops only later in ontogeny (Berrill 1987). It thus appears to be a secondary development, which may indeed be confined to the single order Branchiostomatoidea, the order that includes all Recent species, whereas the supposed Early Cambrian cephalochordate Yunnanozoon (= Haikouella) is comparable to craniates in cephalization and a notochord reaching to the hypophysial region (Mallatt \& Chen 2003). In ontogeny the notochord develops by pinching off the dorsal region of the gut (the archenteron), and is thus confined to the post-oral region behind the hypophysis. From a functional point of view the anterior extension, which follows in Branchiostoma, provides a stiffening, which might originally have been an important adaptation to burrowing. It might also have impeded cephalization in branchi- 
ostomatoids (and also in Palaeobranchiostoma), and in any cephalochordates possessing this adaptation, but not in Early Cambrian Yunnanozoon. Raineri (2006), however, has countered homology of the notochord in Branchiostoma and craniates.

There is no certain evidence for a notochord in conodont body fossils. Briggs (2003: 277) stated that "Paired axial lines that run the length of the trunk might represent the gut or the notochord." If this structure is a notochord, then its extent conforms to the general condition found in Tunicata and Craniata, not the adult branchiostomatoidean condition. We have argued above that forward growth of the notochord is a specialized adaptation to a burrowing habit, and may not be of more than ordinal value as a distinguishing feature. There is every reason to think that it was not characteristic of early cephalochordates (Yunnanozoon; Mallatt \& Chen 2003), any more than it is found in any other group of protochordates.

\section{Skeletal elements}

Vertebrates possess skeletal elements in addition to the notochord. Apart from (internal) viscero- and neurocrania, these comprise first, the segmentallyarranged paraxial elements (of bone or cartilage), which later give rise to such structures as the vertebrae and ribs; and, second, dermal elements, consisting primarily of bone and dentine, and forming scales, teeth and fin rays (thus excluding hagfishes). In nearly all known early vertebrates, these odontodes form an exoskeleton but can also be found lining the internal surface of the mouth to the pharynx, a feature retained in many living fishes (e.g., Reif 2002; Märss et al. 2007). Reif (2006 and references therein: e.g., Fig. 2E) has discussed the errors of Donoghue's (1998) interpretation of conodont morphogenesis providing clear morphogenetic diagrams for vertebrate odontodes and showing how the structure and growth of conodont elements does not match the Odontode Regulation Theory (Reif 2002) in any way. As noted above, Trotter et al. (2007) also showed that conodont element tissues are clearly distinct in crystal size from any vertebrate tissue. There is also no mineralized keratin in conodont elements, and so affinities with rasping teeth of lampreys and hagfishes are also very unlikely.
Despite a few older claimed records, definite "fish" scales per se (i.e. non-conodont elements) first appear in the fossil record in the Early Ordovician (Turner et al. 2004; Young 1997, 2009). Lampreys possess the paraxial elements but lack dermal elements (see also Fin-rays section). Their possession of endoskeletal fin rays is not evidence of an ancestor possessing a dermal skeleton. Hagfishes possess a caudal cartilage with cartilaginous rays (Retzius 1892; homology to radial or fin rays uncertain). Branchiostoma lacks both paraxial dermal and endoskeletal elements.

Conodont body fossils also lack any trace of paraxial, dermal or endoskeletal elements (see conclusions). Nevertheless, elements in the caudal region were compared with those in hagfish by Janvier (1998). Samples of disjunct conodont elements from throughout the stratigraphic range of the group show no evidence of skeletal elements in the organism other than those of an anterior feeding apparatus. Conopiscius Briggs \& Clarkson, 1987, found in the Carboniferous Granton Shrimp Beds with Clydagnathus?, possibly had mineralized scales associated with its $\mathrm{V}$-shaped myomeres, and was claimed as an agnathan; Dzik (2009) recently asserted a conodont affinity for Conopiscius, but its relationships, and the presence of scales, are still uncertain.

\section{Folding of the muscular somites}

Each muscle segment of Branchiostoma is folded into a $\mathrm{V}$ shape, with the angle of the $\mathrm{V}$ directed forward. All craniates, including hagfishes, lampreys and gnathostomes, and even the earliest fossil fish, in which the structure can be distinguished, show a more elaborate folding, into a W shape. In effect, the dorsal and ventral wings of the W-shaped muscle block provide a separately controllable musculature for the compressed dorsal and ventral body margins and for the median fins, where present. The V-shaped pattern could be interpreted as another indication of a convergent evolution of free-moving animals compared to craniates (Raineri 2006).

Conodont body fossils show V-shaped folding with the angle of the $\mathrm{V}$ directed forward (Fig. 1A). This, indeed, forms the basis of one of the argu- 
ments for their chordate nature (Donoghue et al. 2000). They lack any anteriorly-directed refolding of the wings of the $\mathrm{V}$ to form a W shape. In this they are compatible with a cephalochordate condition, not with craniates. However, whereas young vertebrate embryos have $\mathrm{V}$-shaped myotomes (many examples in Moser et al. 1984), this may be interpreted as a plesiomorphous state and does not help with conodont relationships.

\section{Fin rays}

With the exception of hagfishes, the dermal median fins of craniates are supported by endoskeletal fin radials, which are articulated at the base and supplied with a musculature derived from the forwardlyreflected wings of the W-shaped somites. The fins of Branchiostoma, in contrast, are supported by passive non-segmental box-like structures, which lack musculature or basal articulation and provide merely a stiffening (Fig. 4B).

The median fins are clearly supported by some kind of "fin rays" in conodont body fossils. These "fin rays", however, seem not to correspond to the muscular somites and lack any trace of basal articulation or musculature. Indeed, with simple $\mathrm{V}$-folding of the somites the basis for any fin-ray musculature is lacking. Accordingly, the conodont fin rays are more like the Branchiostoma box rays than the fin radials of craniates.

\section{Gill slits}

Cephalochordates possess U-shaped gill slits, which form two slits or openings that are homologous to one primary gill slit of a craniate. Despite the many conodont animals having been studied, only one is reported to show structures that have been interpreted, very tentatively, as four possible gill pouches (Briggs et al. 1983: fig. 3A; Donoghue et al. 2000: fig. 3C). However, we cannot identify these structures in those published figures. Considering that eyes, eye muscles, myomeres, notochord and caudal fin rays have supposedly been identified, it seems unlikely that gill structures would not also have been preserved in conodont specimens, if they were actually present. By comparison, they are present in the Chinese Cambrian chordates (e.g., Shu et al. 2003) and fossil hagfishes and lampreys.
Sansom et al. (2010) proposed a new approach in experimental taphonomy of basal and early chordates in order to constrain the interpretations of their soft-bodied fossil representatives, and consequently to improve the analysis of the phylogenetic relationships. They thus focussed on individual character changes dependent on decomposition stages rather than on features of whole organisms. This way of analysing fossils is certainly interesting and promising. However, Sansom et al. (2010) published only a limited decay study based on only three specimens each of Branchiostoma and Ammocoetus (= Lampetra larva). [Three may be considered as statistically weak, but we can surmize that this is only a preliminary study.] They let the specimens rot without sediment cover, which would have protected the decaying specimen in most natural cases. Soft tissue preservation (except impregnated soft tissue) requires immediate cover and in addition special conditions within the sediment. Even with such conditions, each organism reacts differently, e.g., fat content is different from group to group, etc. (e.g., Schäfer 1972). Sansom et al. (2010: fig. 3) presented a sequence of resulting decay events on a simple tree for both species. They established five decay stages for the two specimens, from the complete specimen to a stage with notochord and some indication of muscle myomeres. The gill basket resists decay to a late stage - in Branchiostoma to stage 4 (their "stem chordate") and in Lampetra to stage 3 (their "stem vertebrate"). They transferred their interpretations onto a deuterostome phylogeny (Sansom et al. 2010: fig. 1a) to show the possible position of several chordate and vertebrate fossils showing exceptional (soft tissue) preservation, which have been subjected to varying interpretations and placement in phylogenies.

One has to distinguish here between different interpretations of structures and the decay process. The yunnanozoans are extremely well preserved even with buccal tentacles, and thus show no decay comparable with Sansom et al.'s (2010: fig. 2) decay sequence and so their different placement in phylogenies are actually differences in interpretation (in contrast to Briggs 2010). In 
reality, one can only be certain of the original form of a decay or fossilization process if the original form is found, as in the case of scaumenallization (Béland \& Arsenault 1985). Sansom et al. (2010) omitted conodonts. Conodont fossils have no gills although supposed eyes are well preserved (decay stage 2 of larval Lampetra). Based on the decay schedules given by Sansom et al. (2010), conodonts would not even fit their "stem chordate" stage. That supports our conclusion on other reasoning presented here that conodonts were not even chordates.

\section{Pathology}

Pathological factors often illuminate morphogenesis. Hass (1941: pl. 13; figs 4, 5), writing on conodont element morphology, considered rejuvenation of injured parts; he noted that it is mostly thinner extremities that are broken away, and that the element can be rejuvenated or rebuilt, although the new growth axes do not always align with the old, and that there can be several restorations. Hass (1941) also referred to an observation by Furnish (1938: pl. 41 fig. 31) on a partly regenerated Early Ordovician specimen of Drepanodus subarcuatus: "Since the cusp is thin and blade-like, most specimens are broken and many individuals show evidence of replacement in the apical portion"; and also discussed "Suppression of parts" [presumably cf. "suppressed denticles" per various glossaries] where he indicated that growth axes are suppressed during growth mostly by lack of room. These elements do show mode of growth, but it is quite different from that of vertebrate odontodes (cf. Reif 1982, 2002). Lindström (1964: fig. 3C) gave a good example of a thin section through a regenerated break, and he also discussed the process of regrowth at length (see also Gross 1954; Fig. 2B). Weddige (1990) documented numerous abnormalities from developmental and traumatic causes, and gives sufficient detail to show that conodonts have no pathologies that relate them to equivalent anomalies in the dentition of lower vertebrate hard tissues (e.g., Reif 1984); consequences of trauma and disease in vertebrate hard parts differ significantly from equivalent accidents in conodonts, in that they are generally not repaired.

\section{THE NEW CLADISTIC ANALYSIS}

It has now been accepted for some time that what is still informally called "agnathan fishes" corresponds to a paraphyletic grouping, incorporating both extant (cyclostomes) and extinct (ostracoderms) taxa. The phylogenetic relationships of the parts of this group (myxinoids, lampreys, pteraspidomorphs, anaspids, osteostracans, galeaspids, pituriaspids, thelodonts) are still currently discussed, and cannot be considered as resolved (see e.g., the various proposals by Janvier 1981, 1997, 1998, 2001, 2003, 2006, 2007a, b, 2008, 2009; Märss et al. 2007). However, this paraphyletic group is at the crux of vertebrate evolution, especially regarding the origin of the head and neural crest-derived tissue (Northcutt 1996). In contrast to the living Branchiostoma (Holland \& Holland 2001), extant and extinct lampreys (e.g., Hardisty \& Potter 1972) and all other vertebrates (e.g., Janvier 2008) possess a complex brain and placodes that contribute to well-developed eyes, as well as auditory and olfactory systems, i.e. they are craniates. These sensory systems were arguably a trigger to subsequent vertebrate diversifications. However, although these systems are known from skeletal forms and other impressions in agnathans (e.g., Märss et al. 2007; Janvier 2008), the vertebrate structures identified in the Early Cambrian Myllokunmingia (= Haikouichthys) from the Chengjiang Fossil-Lagerstätte are doubted, despite Shu et al.'s $(1999,2003)$ and Zhang et al.'s (2001) claims to the contrary. Although Myllokunmingia resembles somewhat the ammocoete larva of modern lampreys, there is no evidence of vertebrate hard tissues nor of a brain; nevertheless, a purported branchial system with gill pouches is present. Chengjiang fossils are preserved as coloured stains, indentations and impressions on the rock matrix, as is the case with fossil softbodied hagfishes and lampreys. Here we include them in two of our analyses, coded in accordance with these structures being correctly identified by the original authors, but have also processed the data with only the taxa used in Donoghue et al.'s (2000) original matrix. One change was made to their taxa, by our nominating the species for the thelodont genus Loganellia, viz. L. scotica, as some 
characters code differently for other thelodont taxa (cf. Märss et al. 2007).

Donoghue et al.'s (2000) analysis is based on their a priori assumption that euconodonts are chordates. As noted by Janvier (2003: 526), "The position of euconodonts [...] in most current phylogenies is largely imposed by assumptions [our emphasis] about the presence of certain characters such as extrinsic [sic] eye muscles or gills". Despite being unconvinced that gills are present in conodonts, we have kept the gill-character codings used by Donoghue et al. (2000), even though we regard the "?" state as being nonapplicable rather than unknown for conodonts.

Despite the various pros and cons of different approaches to taxon sampling and character coding, as discussed by Donoghue et al. (2000), we have followed their methods, taxa and characters as closely as possible. The main revision to the data matrix of Donoghue et al. (2000) is our deletion of the physiological and other characters $(6,9-13$, $24,33,36,39,42,53,56,57,83-103)$ that are not known for any fossil taxa (euconodont, agnathan or gnathostome; see Appendix 1). Otherwise, we have minimized changes to the original characters, altering their character 27, pouch-shaped gills, to our character 20, gill opening shape: 0 -, simple slit; 1-, pore; 2-, slit opening to chamber, so that tunicates and jawed fishes code differently, and altering their character 41, large lateral head vein, to our character 31 , lateral head vein. In this new analysis, character codings have been revised as detailed in Appendix 2. The character matrix (Table 2) incorporates revisions based on recent publications on several taxa; in particular the new description of Euphanerops (Janvier \& Arsenault $2007)$ led to changes in codings for characters 6 (7), 21 (28), 25 (32), $26(34), 29$ (38), 33 (44), 36 (47), 37 (48), 39 (50), 42 (54), 43 (55), 44 (58), 48-60 (62-74), 66 (80), and 67 (81). Donoghue et al. (2000) used PAUP 3.1.1 for their parsimony analysis, whereas we used the updated PAUP 4.0b10 program for Windows (Swofford 2002), while also using equal-weight, unordered multistate characters, and branch-and-bound tree-building routine (i.e. heuristic search), but with a data matrix of just 68 of the original 103 characters.
The article by Donoghue et al. (2000) included cladistic analyses of chordates (including conodonts, with the a priori assumption that they are chordates) that incorporated physiological as well as morphological and histological characters. In their cladogram and even in their preferred trees (Donoghue et al. 2000: fig. 14a: ACCTRAN [= accelerated character state transformation], fig. 14b: DELTRAN [= delayed character state transformation]), the position of conodonts is poorly supported as they sit above a node that is characterized by 45 synapomorphies in their fig. $14 \mathrm{a}$ (39 in their fig. 14b) above the node Craniata with Cephalochordata, of which conodonts have only seven codable characters $(1,2,19,28$, 46, 51 and 65), i.e. only 16\% (ibid., fig. 14b: $18 \%$ ); thus $84 \%$ (ibid., fig. 14 b: $82 \%$ ) are missing or inapplicable. In addition, only two of the 20 homoplasies are present in conodonts, i.e. only 10\% (Donoghue et al. 2000: fig. 14b: 14\%) present; a third homoplasy (character $50=$ preanal median fold) below the node is even coded 0 for conodonts. This is both an illogical and unexplainable position for conodonts. Nevertheless, these authors dismissed all other contemporary views of conodont relationships as virtually unscientific because they did not include a "numerical cladistic analysis". Their approach, we contend, was actually based on a preferential data set, with a near-complete data matrix only being possible for extant rather than fossil taxa. Their main analysis resulted in the conclusion that conodonts "are the most plesiomorphic member of the total group [our emphasis] Gnathostomata" (Donoghue et al. 2000: 191; also Gess et al. 2006). This leads to a semantic inconsistency (see discussion above) because "gnathostomes" are defined as jawed vertebrates with teeth; as noted above, a "stem" gnathostome without teeth therefore cannot be a gnathostome and be within the "total group" and conodont elements are therefore not homologous with vertebrate teeth (e.g., Gross 1954; Schultze 1996; Kemp 2002a; Reif 2006). Reif (2004) also discussed the misunderstanding of Hennig's usage of "stem group" and the "Total Group Concept" of Jefferies (1979) showing that Hennig never intended his method to be extended back in time. 
TABLE 2. - Data matrix for the 17 original taxa used by Donoghue et al. (2000: table 1) plus Myllokunmingia and Yunnanozoon. "?" applies to both inapplicable and unknown codings. Multiple state character codings are unordered, the default "MSTaxa = uncertain" (rather than "polymorph" or "variable") was used.

Our character nos.

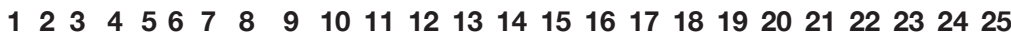

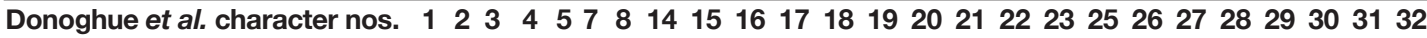

Tunicata

Cephalochordata

Myxinoidea

Petromyzontida

Heterostraci

Astraspis

Eriptychius

Arandaspida

Anaspida

Jamoytius

Euphanerops

Osteostraci

Galeaspida

Loganellia scotica

Pituriaspida

Jawed vertebrates

Conodonta

Yunnanozoon/Haikouella

0 ? $0 \begin{array}{llllllllllllllllllllll}0 & 0 & 0 & 0 & 0 & 0 & 0 & 0 & 0 & 0 & 0 & 0 & 0 & 0 & 0 & 0 & 0 & ? & ? & ? & ? & 0\end{array}$

Myllokunmingia/Haikouichthys

$\begin{array}{lllllllllllllllllllllllll}0 & 0 & 0 & 0 & 0 & 0 & 0 & 0 & 0 & 0 & 0 & 0 & 0 & 0 & 0 & 0 & 0 & 0 & 0 & 0 & 0 & 0 & 0 & 0 & 0\end{array}$

$\begin{array}{lllllllllllllllllllllllll}1 & 1 & 0 & 0 & 1 & 1 & 0 & 2 & 1 & 1 & 1 & 1 & 0 & 1 & 0 & 0 & 0 & 1 & 1 & 1 & 0 & 0 & 0 \backslash 1 & 0 & 0 \backslash 1\end{array}$

$\begin{array}{lllllllllllllllllllllllll}1 & 1 & 0 & 2 & 1 & 1 & 1 & 2 & 1 & 1 & 2 & 1 & 1 & 2 & 0 & 0 & 1 & 2 & 1 & 1 & 1 & 1 & 1 & 0 & 0\end{array}$

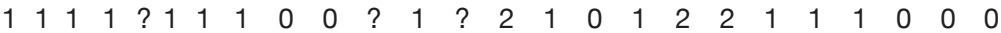

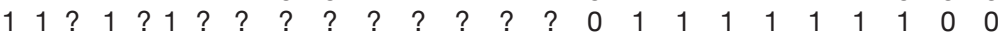

11 ? ? ? 1 ? ? ? ? ? ? ? ? ? ? ? ? ? 1 ? ? ? ? ?

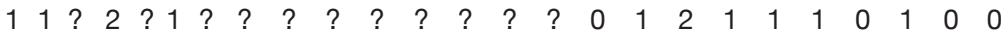

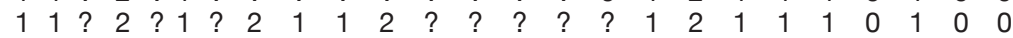

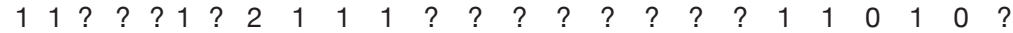

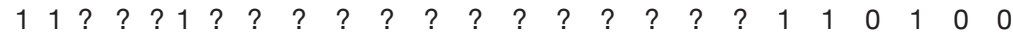

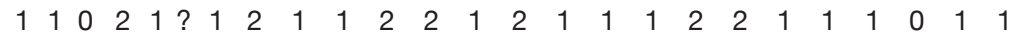

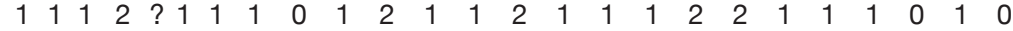

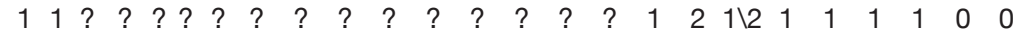

11 ? ? ? ? 1 ? ? ? ? ? ? ? ? ? ? ? ? ? ? ? ? ? ?

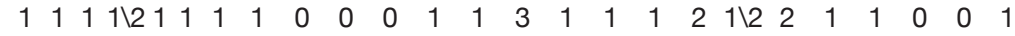

? ? ? ? ? ? ? ? ? ? ? ? ? ? ? ? ? ? ? ? ? ? ? ?

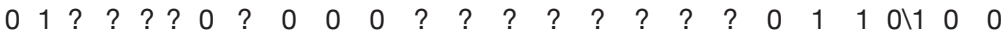

Our character nos.

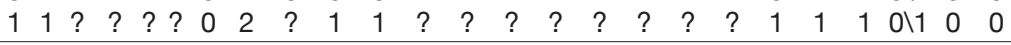

$\begin{array}{llllllllllllllllllllllllll}\text { Donoghue et al. character nos. } & 34 & 35 & 37 & 38 & 40 & 41 & 43 & 44 & 45 & 46 & 47 & 48 & 49 & 50 & 51 & 52 & 54 & 55 & 58 & 59 & 60 & 61 & 62\end{array}$

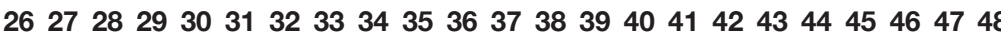

Tunicata

Cephalochordata

Myxinoidea

Petromyzontida

Heterostraci

Astraspis

Eriptychius

Arandaspida

Anaspida

Jamoytius

Euphanerops

Osteostraci

Galeaspida

Loganellia scotica

Pituriaspida

Jawed vertebrates

Conodonta

Yunnanozoon/Haikouella

$0 \begin{array}{llllllllllllllllllllll}0 & 0 & 0 & 0 & 0 & 0 & 0 & 0 & 0 & 0 & 0 & 0 & 0 & 0 & 0 & 0 & 0 & 0 & 0 & 0 & 0 & 0\end{array}$

Myllokunmingia/Haikouichthys

$\begin{array}{llllllllllllllllllllllllll}0 & 0 & 0 & 0 & 1 & 1 & 1 & 0 \backslash 1 & 0 & 0 & 0 & 0 & 1 & 1 & 1 & 1 & 0 & 0 & 0 & 0 & 0 & 0 & 0\end{array}$

$\begin{array}{lllllllllllllllllllllll}1 & 0 & 1 & 1 & 0 & 1 & 0 & 1 & 1 & 0 & 0 & 0 & 1 & 0 & 1 & 1 & 1 & 1 & 1 & 0 & 0 & 1 & 0\end{array}$

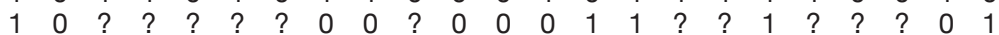

? ? ? ? ? ? 110000 ? 0 c 0 ?

? ? ? ? ? ? ? ? ? ? ? ? ? ? 1 ? ? ? ? ? ? ? 1

? 0 ?

? 0 ?

? 1 ?

$\begin{array}{lllllllllllllllllllllllllllllllll} & 1 & 0 & ? & 1 & ? & ? & ? & 0 & 1 & 1 & 1 & 0 & 1 & 0 & 1 & ? & 0 & 1 & 0 & ? & ? & 1 & 0\end{array}$

$\begin{array}{lllllllllllllllllllllll}1 & 1 & 1 & 1 & 0 & 1 & 1 & 1 & 0 & 1 & 0 & 1 & 2 & 0 & 1 & 1 & ? & 1 & 1 & 1 & 1 & 0 & 1\end{array}$

$\begin{array}{lllllllllllllllllllllll}1 & 1 & ? & ? & ? & 1 & 1 & 0 & 0 & \text { ? } & 0 & 0 & ? & 0 & 1 & 1 & ? & 1 & 1 & 1 & 1 & 0 & 1\end{array}$

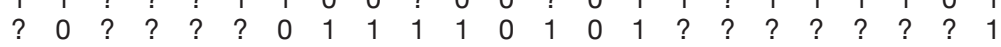

? 1 ? ? ? ? ? ? ? ? ? ? 1 ? ? ? 1 ?

$\begin{array}{lllllllllllllllllllllll}1 & 0 & 1 & 1 & 1 & 1 & 0 \backslash 1 & 1 & 1 & 1 & 0 \backslash 1 & 1 & 2 & 0 & 1 & 0 & 0 & 1 & 1 & 1 & 1 & 0 & 1\end{array}$

? ? ? ? ? ? ? ? 0 ? 0 ?

$\begin{array}{lllllllllllllllllllllll}1 & 0 & ? & ? & ? & ? & ? & 0 & 0 & ? & 0 & 0 & 0 & 0 & 0 & 0 & 0 & 0 & 0 & 0 & ? & ? & 0\end{array}$

$\begin{array}{llllllllllllllllllllllll} & 0 & & \text { ? } & \text { ? } & ? & ? & ? & 1 & ? & 1 & 1 & 0 & ? & 0 & \text { ? } & 0 & ? & 1 & 0 & 0 & \text { ? } & \text { ? } & 0\end{array}$

Donoghue et al. (2000) included numerous variations of their main analysis, which they used to illustrate "worst case" scenarios by leaving out all characters for which fossil taxa coded "?", and changing the conodont coding to 0 for several contentious characters (eye muscles, histology). Their "worst" result showed conodonts as more derived (crownward) than hagfishes (Donoghue et al. 2000: fig. 11D). We present here a review of the morphological and histological characters, which leads us to consider that conodonts are neither vertebrates nor craniates. Using these characters, we present a new cladistic analysis that counters the conclusions of the Donoghue et al.'s 


\begin{tabular}{lcccccccccccccccccccc}
\hline Our character nos. & $\mathbf{4 9}$ & $\mathbf{5 0}$ & $\mathbf{5 1}$ & $\mathbf{5 2}$ & $\mathbf{5 3}$ & $\mathbf{5 4}$ & $\mathbf{5 5}$ & $\mathbf{5 6}$ & $\mathbf{5 7}$ & $\mathbf{5 8}$ & $\mathbf{5 9}$ & $\mathbf{6 0}$ & $\mathbf{6 1}$ & $\mathbf{6 2}$ & $\mathbf{6 3}$ & $\mathbf{6 4}$ & $\mathbf{6 5}$ & $\mathbf{6 6}$ & $\mathbf{6 7}$ & $\mathbf{6 8}$ \\
\hline Donoghue et al. character nos. & $\mathbf{6 3}$ & $\mathbf{6 4}$ & $\mathbf{6 5}$ & $\mathbf{6 6}$ & $\mathbf{6 7}$ & $\mathbf{6 8}$ & $\mathbf{6 9}$ & $\mathbf{7 0}$ & $\mathbf{7 1}$ & $\mathbf{7 2}$ & $\mathbf{7 3}$ & $\mathbf{7 4}$ & $\mathbf{7 5}$ & $\mathbf{7 6}$ & $\mathbf{7 7}$ & $\mathbf{7 8}$ & $\mathbf{7 9}$ & $\mathbf{8 0}$ & $\mathbf{8 1}$ & $\mathbf{8 2}$ \\
\hline Tunicata & 0 & 0 & 0 & 0 & 0 & 0 & 0 & 0 & 0 & 0 & 0 & 0 & 0 & 0 & 0 & 0 & 0 & 0 & 0 & 0 \\
Cephalochordata & 0 & 0 & 0 & 0 & 0 & 0 & 0 & 0 & 0 & 0 & 0 & 0 & 0 & 0 & 0 & 0 & 0 & 0 & 0 & 0 \\
Myxinoidea & 0 & 0 & 0 & 0 & 0 & 0 & 0 & 0 & 0 & 0 & 0 & 0 & 0 & 0 & 0 & 0 & 0 & 0 & 0 & 0 \\
Petromyzontida & 0 & 1 & 0 & 0 & 0 & 0 & 0 & 0 & 0 & 0 & 0 & 0 & 0 & 0 & 0 & 0 & 0 & 0 & 0 & 0 \\
Heterostraci & 0 & 0 & 1 & 1 & 1 & 0 & 2 & 0 & 1 & 1 & 2 & 112 & 1 & 1 & 0 & 2 & 1 & 0 & 0 & 0 \\
Astraspis & 0 & 0 & 1 & 1 & 1 & 0 & 2 & 2 & 1 & 0 & 2 & 1 & 1 & $?$ & $?$ & 1 & 0 & $?$ & $?$ & 0 \\
Eriptychius & $?$ & 1 & 1 & 1 & 1 & 0 & 2 & 2 & 1 & 0 & 2 & 1 & 0 & $?$ & $?$ & 1 & 0 & $?$ & $?$ & $?$ \\
Arandaspida & $?$ & $?$ & 1 & 1 & 1 & 0 & 0 & 0 & 1 & 1 & 2 & 2 & 1 & 1 & 0 & 2 & 1 & $?$ & 1 & 1 \\
Anaspida & 0 & 0 & 1 & 0 & 1 & 0 & 0 & 0 & 0 & 0 & 2 & 2 & 0 & 1 & 0 & 1 & 0 & 0 & 0 & 0 \\
Jamoytius & $?$ & $?$ & 1 & $?$ & $?$ & $?$ & $?$ & $?$ & $?$ & $?$ & $?$ & 2 & 0 & 0 & 0 & 0 & 0 & 0 & 0 & 0 \\
Euphanerops & 0 & 1 & 0 & 0 & 0 & 0 & 0 & 0 & 0 & 0 & 0 & 0 & 0 & 0 & 0 & 0 & 0 & 1 & 0 & 0 \\
Osteostraci & 1 & 1 & 1 & 0 & 0 & 1 & 1 & 0 & 1 & 0 & 2 & 1 & 0 & 1 & 0 & 2 & 0 & 1 & 1 & 1 \\
Galeaspida & 1 & 1 & 1 & 0 & 1 & 0 & 0 & 0 & 0 & 0 & 1 & 1 & 0 & 1 & 0 & 2 & 0 & 1 & 1 & 0 \\
Loganellia scotica & 0 & 0 & 1 & 0 & $?$ & 0 & 1 & 0 & 0 & 0 & 1 & 1 & 0 & 0 & 1 & 1 & 0 & 0 & $?$ & 0 \\
Pituriaspida & 1 & $?$ & 1 & $?$ & $?$ & $?$ & $?$ & $?$ & $?$ & $?$ & $?$ & $?$ & 0 & $?$ & $?$ & 2 & 1 & 1 & $?$ & $?$ \\
Jawed vertebrates & 1 & 1 & 1 & 0 & 0 & 1 & 1 & 1 & 1 & 0 & 2 & 1 & 0 & 0 & 1 & 1 & 0 & 0 & 1 & 1 \\
Conodonta & 0 & 0 & 0 & 0 & 0 & 0 & 0 & 0 & 0 & 0 & 0 & 0 & 0 & 0 & 0 & 0 & 0 & 0 & 0 & 0 \\
Yunnanozoon/Haikouella & 0 & 0 & 0 & 0 & 0 & 0 & 0 & 0 & 0 & 0 & 0 & $?$ & 0 & 0 & 0 & 0 & 0 & 0 & 0 & 0 \\
Myllokunmingia/Haikouichthys & 0 & $?$ & 0 & 0 & 0 & 0 & 0 & 0 & 0 & 0 & 0 & $?$ & 0 & 0 & 0 & 0 & 0 & 0 & 0 & $?$ \\
\hline
\end{tabular}

(2000) analysis. However, our main criticisms of the claims of the "British School" are based on sound morphological and histological arguments that really do not rely on a computer.

Before giving the results of our new phylogenetic analysis, we want to mention three recent analyses that resulted in differing conodontvertebrate relationships: 1) conodonts with "?" in polytomy with lampreys, etc.: (myllokunmingiids (hagfishes, lampreys, ? euconodonts, Euphanerops (anaspids ((arandaspids, astraspids, heterostracans) (thelodonts (galeaspids (pteraspids, osteostracans, jawed vertebrates))))))) (Janvier 2007a: fig. 1.13). In this analysis, Janvier (2007a: 32) considered that euconodonts are "regarded by many paleontologists as the basalmost stem gnathostomes", he cited only Schultze's (1996) paper with opposing opinion, and continued: "The phylogenetic position of euconodonts as stem gnathostomes remains tenuously supported, and they may turn out to be either more closely related to hagfishes or lampreys (or cyclostomes as a whole), or even stem vertebrates." (for a further opinion, see Janvier 2008); 2) conodonts with "?" in polytomy with anaspids etc.: (cephalochordates (Myllokunmingiida (hagfishes, lam- preys, ? Euphaneropidae (? Euconodonta, Anaspida, (Arandaspida, Astraspida, Heterostraci), Thelodonti (Galeaspida (Pituriaspida, Osteostraci (Placodermi $($ Chondrichthyes (Acanthodii, Osteichthyes) $))))))$ )) (Janvier 2007b: fig. 2.3), with the relationships of euconodonts to or within vertebrates still debated by this author (Janvier 2007b: 65): "Euconodonts share with crown-group vertebrates the presence of median fin radials and are best placed as stem gnathostomes, notably on the basis of their ability to develop mineralized skeletal elements made of apatite"; and Janvier (2008) who places the conodonts in his cladogram with a question mark, and a polytomy; and 3) conodonts below (more stem-ward of) craniates (our position): (Cephalochordata (Haikouella (Conodonta (Myxinida (Petromyzontida (Heterostraci (Anaspida (Thelodontida (Osteostraci (Placodermi (Chondrichthyes $($ Acanthodii, Osteichthyes))) )) )) )))) (Wilson et al. 2007: fig. 3.1).

Since our paper was proposed for publication, a series of papers appeared in various books and journals of biology and/or palaeontology (Janvier 2008, 2009; Donoghue et al. 2008; Koentges 2008; Paris et al. 2008; Aldridge \& Briggs 2009; Huysseune et al. 2009; Sire et al. 2009). These authors 
A

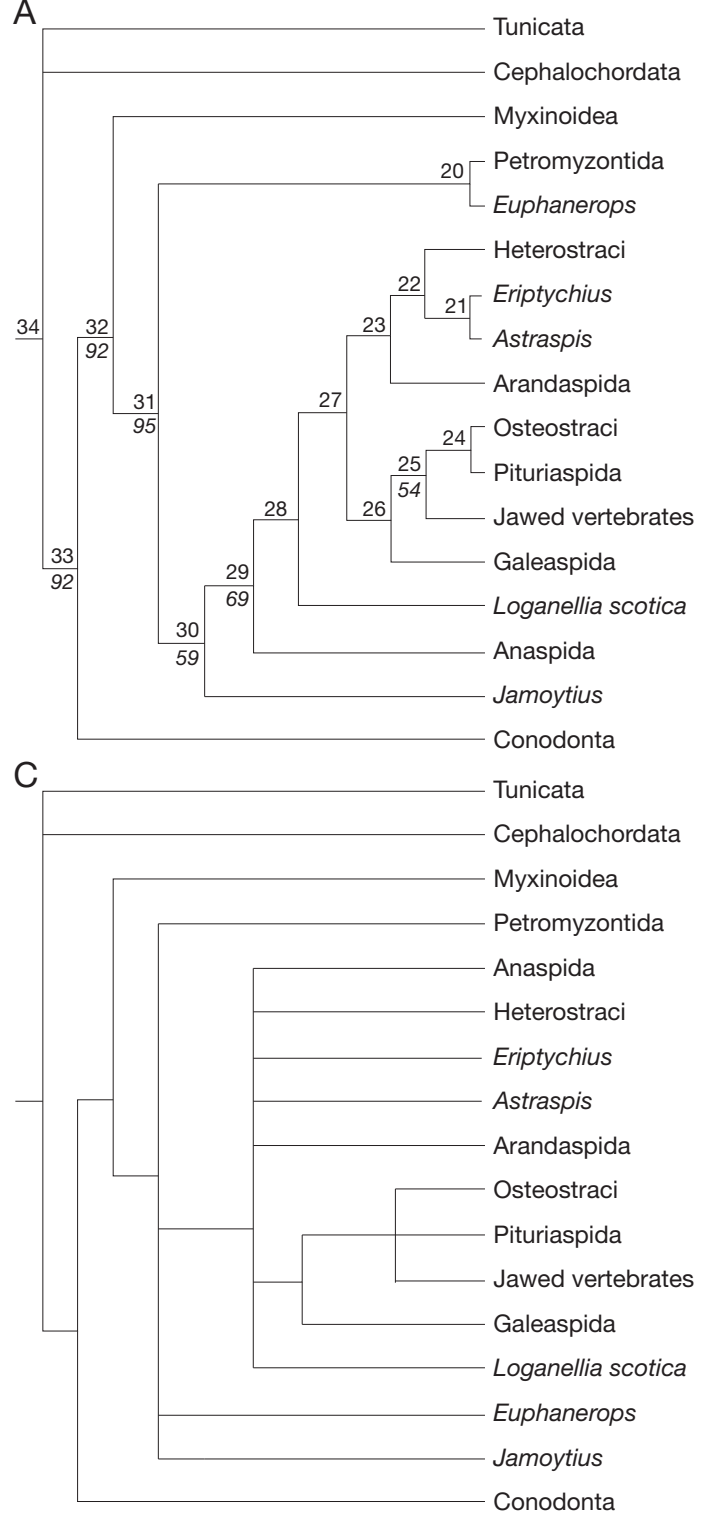

B

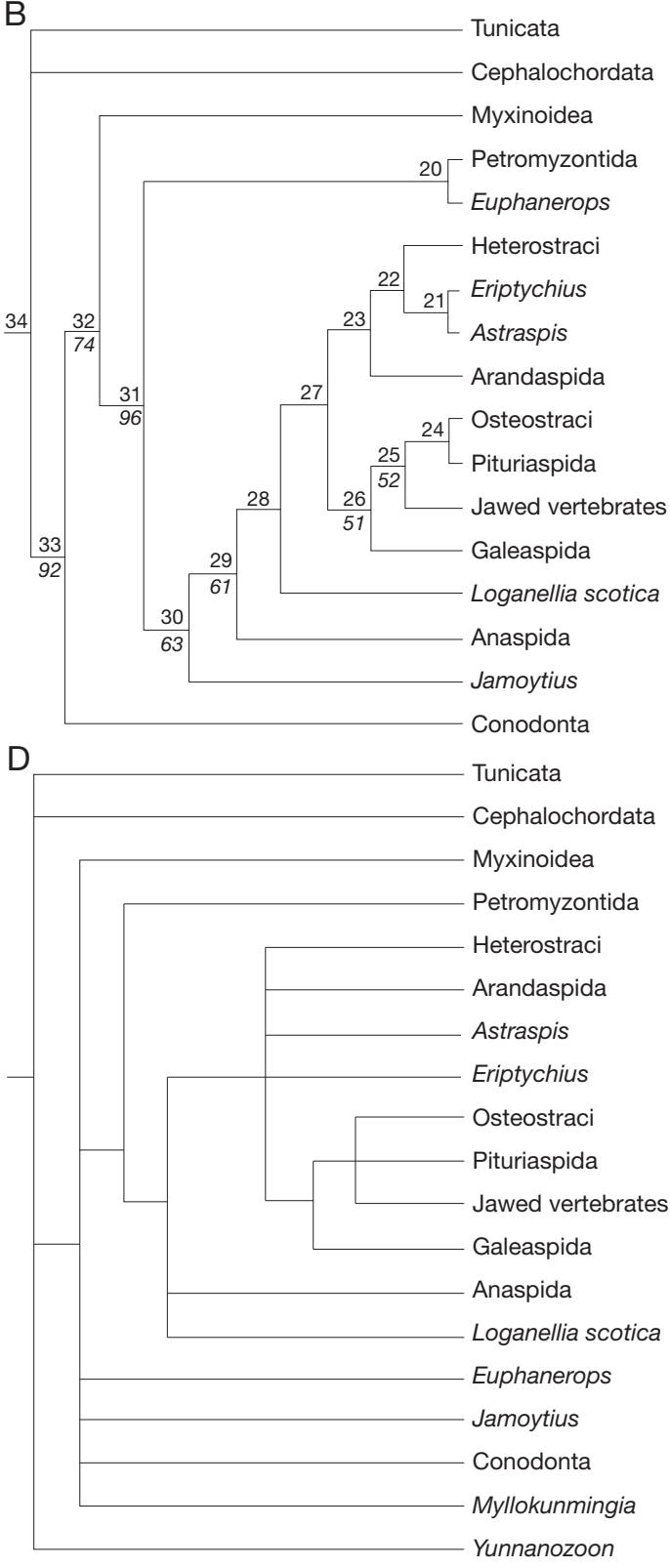

FIG. 5. - Cladograms generated by PAUP 4.01b10 for Windows (Swofford 2002), data (see Table 2) compiled with NEXUS Data Editor (Page 1999), using 68 unordered, equal weight characters, heuristic search, starting trees obtained by stepwise addition with random addition sequence, tree-bisection-reconnection branch swapping; trees generated using Treeview X (Page 1996): A-C, using the original 17 taxa, characters of Donoghue et al. (2000) recoded (see Appendices 1; 2); Consistency index $(\mathrm{Cl})=0.5971$, Homoplasy index $(\mathrm{HI})=0.4029$, and Retention index $(\mathrm{Rl})=0.6940$ (see Appendix 4 for $\mathrm{Cl}, \mathrm{HI}$ and $\mathrm{RI}$ values for the single characters); 27 shortest trees of equal length $=139$ steps, with numbered nodes (cf. apomorphy lists, Appendix 3) for the trees illustrated and $50 \%$ majority rule bootstrap values given in italics (under node number) at nodes supported by the bootstrap analyses; A, ACCTRAN character-state optimisation (accelerated appearance of character states), tree 6 of 27 equal length trees; B, DELTRAN character-state optimisation (delayed appearance of character states), tree 4 of 27 equal length trees; C, strict consensus of 27 shortest trees for the original 17 taxa; $\mathbf{D}$, strict consensus of 207 shortest trees (DELTRAN) or 212 shortest trees (ACCTRAN) of equal length $=145$ steps for the original 17 taxa plus Myllokunmingia and Yunnanozoon. 


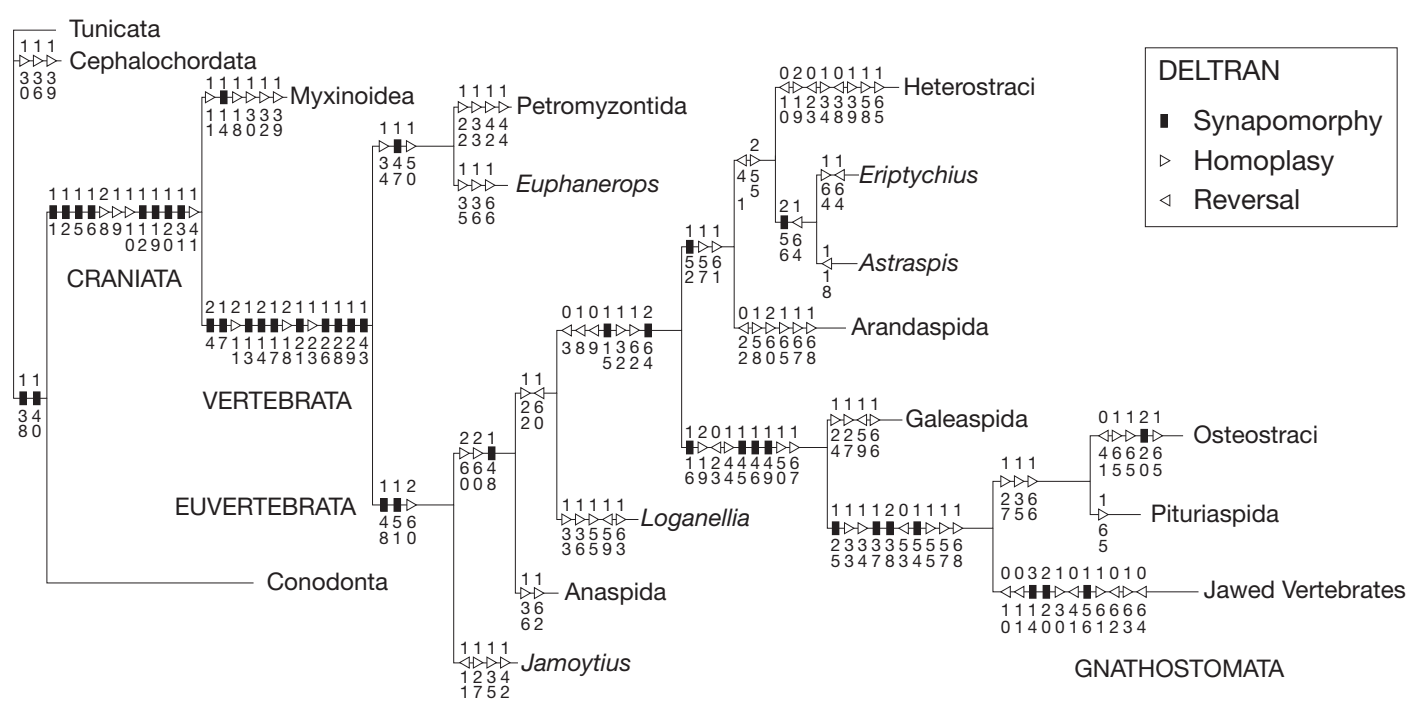

FIG. 6. - DELTRAN character-optimisation tree with presentation of character changes. See Appendix 1 for character list and character states. CRANIATA, synapomorphies: 1, neural crest present; 2, brain present; $\mathbf{5}$, divided pituitary present; $\mathbf{6}$, optic tectum present; 12, paired olfactory organ; $\mathbf{1 9}$, sensory lines in grooves; $\mathbf{2 0}$, gill openings pouch-shaped ; $\mathbf{3 1}$, lateral head vein present; homoplasies: 8, single nasal opening; 9, nasopharyngeal duct present; 10, single nasopharygeal opening; 41, visceral arches fused to neurocranium; VERTEBRATA, synapomorphies: 4, pineal organ present and uncovered; 7, cerebellum present; 13, extrinsic eye muscles present; 14, two semicircular canals; 17, sensory line system with neuromasts; 21, symmetrical gill position; 26, gill lamellae with filaments; 28, close position of atrium and ventricle; $\mathbf{2 9}$, closed periocardium; 43, arcualia present; homoplasies: 11, dorsal position of nasohypophysial opening; 18, sensory line grooves or canals present on head and body; 23, slanting row of gill openings; EUVERTEBRATA, synapomorphies: 48, dermal trunk skeleton; 51, calcified dermal skeleton; homoplasy: 60, rod-shaped scales; GNATHOSTOMATA, synapomorphies: $\mathbf{1 4}$, three semicircular canals; $\mathbf{2 0}$, gill opening as slits to chambers; $\mathbf{5 6}$, enamel present; homoplasies: $\mathbf{3 0}$, paired dorsal aortae; 61, oakleaf-shaped tubercles; 63, denticles in pharynx; reversals: 10, no single nasohypophysial opening; 11, no nasohypophysial opening; $\mathbf{4 1}$, visceral arches not fused to neurocranium; 62 , no oral plates; 64 , small micromeric dermal head covering in adult state; CONODONTA: no synapomophies in our data matrix, these would be hyaline and albid (white matter) tissue and their connection, base not in unit with crown and conodont apparatus.

accepted in general the conclusions of Donoghue et al. $(2000,2003,2006,2008)$ that conodonts are 1) vertebrates, and 2) "stem gnathostomes". We do not want to comment on these papers in detail here because we focus on the origin of the discussion, that is, the phylogenetic analysis of Donoghue et al. (2000). We emphasize that those papers do not critically evaluate the arguments of Donoghue et al., and that, in some cases, they are contradictory in their own developments (see e.g., Janvier 2009), who says in the English version [p. 211] that "Fossils thus show that bone and teeth have preceded jaws", although in the French version [p. 214] he says that "l'os et la dentine ont précédé l'apparition des mâchoires" - bone and dentine have preceded the occurrence of jaws, but without any mention of teeth.

\section{RESULTS OF THE NEW CLADISTIC ANALYSIS}

Our analysis of the revised data matrix (Table 2) results in cladograms for the original 17 taxa (Figs 5A, B; 6) where (Tunicata + Cephalochordata) appear as sister taxa of (Conodonta + Craniata). Vertebrates (node 31 ) are characterized by nearly the same synapomorphies and homoplasies as in Donoghue et al. (2000), but do not include the conodonts.

The list of characters for craniates in Donoghue et al's (2000: fig. 14a, ACCTRAN) cladogram includes nine synapomorphies and 15 homoplasies. Of these, seven synapomorphies [ $1^{1}\left(1^{1}\right)$ neural crest present, $2^{1}\left(2^{1}\right)$ brain present, $5^{1}\left(5^{1}\right)$ pituitary divided, $6^{1}\left(7^{1}\right)$ optic tectum present, $12^{1}\left(18^{1}\right)$ paired 
olfactory organ, $14^{1}\left(20^{1}\right)$ one semicircular canal, and $40^{1}\left(51^{1}\right)$ ability to synthesise creatine phosphatase] and five homoplasies [ $8^{2}\left(14^{2}\right)$ single median nasal opening, $10^{1}\left(16^{1}\right)$ single nasohypophysal opening, $11^{1}\left(17^{1}\right)$ terminal nasohypophysal opening, $18^{1}\left(25^{1}\right)$ sensory line grooves on head, and $19^{1}\left(2^{1}\right)$ sensory lines in grooves] appear in our ACCTRAN analysis at node 33 (Craniata + Conodonta), even though all these characters are unknown (coded "?", see Table 2) in conodonts. In contrast our ACCTRAN analysis (Appendix 3) shows only one of Donoghue et al.'s (2000) synapomorphies for craniates $\left(40^{1}\left(51^{1}\right)\right.$ ) and one additional homoplasy ( $38^{1}\left(49^{1}\right)$ hypocercal tail) at node 33 (Craniata + Conodonta). This and the following results from our DELTRAN analysis (Figs 5B; 6) are significant differences. Donoghue et al.'s (2000) synapomorphies [11 (11), $2^{1}\left(2^{1}\right), 5^{1}$ $\left(5^{1}\right), 6^{1}\left(7^{1}\right), 12^{1}\left(18^{1}\right)$ and $20^{1}\left(2^{1}\right)$ pouch-shaped gills] and homoplasies [82 (142), $10^{1}\left(16^{1}\right), 1^{1}\left(26^{1}\right)$ and $41^{1}\left(52^{1}\right)$ visceral arches fused to neurocranium] appear at node 32 (Craniata) of our DELTRAN analysis with all of these characters except $41^{1}\left(52^{1}\right)$ being synapomorphies, thus placing the conodonts outside the craniates. Characters $31^{1}$ (411) lateral head vein and $9^{1}\left(15^{1}\right)$ nasopharyngeal duct present are additional synapomorphies at this node in our DELTRAN analysis.

The Vertebrata (Fig. 6; Appendix 3) are characterized by nine synapomorphies [ $7^{1}\left(8^{1}\right)$ cerebellum present, $13^{1}\left(1^{1}\right)$ extrinsic eye musculature, $14^{2}$ $\left(20^{2}\right)$ two semicircular canals, $17^{1}\left(23^{1}\right)$ sensory line system with neuromasts, $21^{1}\left(28^{1}\right)$ symmetrical gill position, $26^{1}\left(3^{1}\right)$ gill lamellae with filaments, $28^{1}$ (371) close position of atrium to ventricle, $29^{1}$ (381) closed pericardium, and $43^{1}$ (551) arcualia present], and two homoplasies [ $4^{2}\left(4^{2}\right)$ uncovered pineal organ, and $18^{2}\left(25^{2}\right)$ sensory grooves and canals on head and body] in our analyses (ACCTRAN and DELTRAN; also both transformations produce the same strict consensus tree, Fig. 5C); two additional different homoplasies appear in ACCTRAN [341 $\left(45^{1}\right)$ anal fin separate, and $50^{1}$ (641) calcified cartilage present] and DELTRAN [112 (172) nasohypophysial opening dorsal, and $23^{1}$ (301) lateral gill openings in slanting row]. Donoghue et al.'s (2000) cladogram shows $24(!)$ additional synapomorphies [(62), (121), (131), (241), (391), (421), (571), (831.
941), (961-991), (1021)] for vertebrates, which are all characters unknown in fossil taxa and therefore eliminated from our analysis, as noted earlier. Character $7^{1}\left[\left(8^{1}\right)\right.$ cerebellum present] appears as an additional synapomorphy for vertebrates in our analyses relative to the synapomorphies in Donoghue et al.'s (2000). Two [42 (42), $34^{1}$ (451)] of the four homoplasies for vertebrates in our ACCTRAN analysis (Fig. 5A; Appendix 3) are not present in Donoghue et al.'s (2000) cladogram, which shows four homoplasies [(291) branchial series with fewer than 10 openings, (301) slanting row of gill openings, (491) hypocercal tail, $\left(50^{\circ}\right)$ no preanal median fold] and two reversals for vertebrates $\left[\left(40^{\circ}\right)\right.$ no paired dorsal aortae, (951) eliminated in our analysis] not present in our analysis. These characters [231 (301), $30^{0}\left(40^{0}\right), 38^{1}\left(49^{1}\right), 39^{0}\left(50^{\circ}\right)$ ] appear more basal in our analyses with the exception of character $22^{1}$ (291) (elongate branchial series), which occurs within lower vertebrates.

In addition, six synapomorphies [ $\left(8^{1}\right)$ cerebellum present, $\left(9^{1}\right)$ pretrematic branches in branchial nerves, (211) vertical semicircular canals forming loops, (411) lateral head vein present, (601) occiput enclosing vagus and glossopharyngeal, and (651) calcified dermal skeleton present] place the conodonts "above" (more crownward) the petromyzontids in Donoghue et al.'s (2000) cladogram. Of these characters, number (9) was eliminated, and numbers 7 (8), 15 (21), 31 (41) and 46 (60) are coded as "?" (unknown) and 51 (65) as "0" (absent) for conodonts in our data matrix.

The position of conodonts in our cladograms (Figs $5 ; 6$ ) is the result of changing the coding of 12 characters (see Appendix 2) for conodonts (1 (1), 2 (2) and 13 (19) from 1 to ?; 20 (27) from 0 to ?; 41 (52), 42 (54), 43 (55), 55 (69) from ? to 0; 51 (65), 56 (70) and 63 (77) from 1 to $0 ; 59$ (73) from 2 to 0$)$. These recodings change the synapomorphies (eight) and homoplasies (three) between conodonts and craniates/vertebrates in Donoghue et al.'s (2000) cladogram. In our data matrix 50\% of our 68 characters are unknown for conodonts (Table 2). The result of our analysis is an improved version of the data set of Donoghue et al. (2000); it demonstrates that conodonts are neither vertebrates nor craniates. 
We also ran the analysis leaving pituriaspids and Eriptychius out of the matrix as most data for these taxa are unknown; the consensus tree did show a little better resolution. Concerning Eriptychius, the phylogenetic position given by Donoghue et al. (2000; also Donoghue \& Aldridge 2001) as the sister-group of gnathostomes appears unusual. After their detailed auto-critical evaluation of the character analysis of Eriptychius, Donoghue et al. (2000: 217) did recognize that they "cannot claim that the evidence for the association of Eriptychius with gnathostomes [...] is well supported". Eriptychius actually has $82 \%$ of missing data in Donoghue et al.'s (2000) paper, and some characters are miscoded. For instance, character 78 (state 1: dermal head covering in adult state small micromeric) does not apply to the dermal head cover of Eriptychius, which is more likely to be meso/ macromeric (Denison 1967). Most characters that link Eriptychius to gnathostomes are homoplastic (Donoghue et al. 2000: fig. 14a, b), and the only one that is resolved as a synapomorphy to both taxa (character 20: number of semi-circular canals in labyrinth) is coded "?" for Eriptychius by Donoghue et al. (2000: table 1). So, their result was not strongly supported and has been abandoned in more recent papers (Donoghue \& Sansom 2002; Donoghue et al. 2003).

In order to test relationships of the purported Chinese Cambrian chordates, we included in our matrix Myllokunmingia, synonymous with Haikouichthys (Hou et al. 2002; Janvier 2003) as noted above, and Yunnanozoon, now considered synonymous with Haikouella. Shimeld \& Holland (2000: fig. 1) showed a hypothesis of phylogenetic relationship between living members of the phylum Chordata plus Myllokunmingia (as a claimed craniate, Holland \& Chen 2001) and Yunnanozoon (= Haikouella, a claimed basal chordate, Mallatt \& Chen 2003), but they left out other claimed fossil chordates, including Pikaia and Cathaymyrus (see above) that they claimed were possibly related to Branchiostoma and the euconodonts (the claimed possible vertebrates). Our analysis shows some support for that of Holland \& Chen (2001) with Myllokunmingia as a vertebrate stemward of Petromyzontida, and Yunnanozoon as a chordate between Tunicata and
Cephalochordata in some of the 200+ best trees. The consensus tree (Fig. 5D) places Tunicata, Cephalochordata, Yunnanozoon and Craniata in a polytomy, and Myllokunmingia with Vertebrata, Myxinoidea, Jamoytius (Fig. 1H), Euphanerops and Conodonta in another polytomy.

However, our consensus trees (Fig. 5C, D) do not help to resolve interrelationships within vertebrates, indicating that the data matrix is not adequate for this purpose, although elimination of poorly known taxa greatly increases the resolution of the analysis.

\section{SUMMARY: WHY CONODONTS ARE NOT VERTEBRATES}

Perhaps development of the (buccal-pharyngeal) bipartite conodont apparatus in advanced para- and euconodonts reflects an alternative pathway to allow a soft-bodied worm-shaped animal to increase in size, support a filter-feeding lifestyle, and even possibly indulge in macrophagy. It is interesting that even the more extreme "conodonts are vertebrates" people seem to accept that protoconodonts are related to chaetognaths (see e.g., in Reif 2006) or even that chaetognaths descend from protoconodonts (Szaniawski 2002). These organisms are sometimes classified among the protostomes (Lecointre \& Le Guyader 2001), sometimes among the deuterostomes (references in Janvier 1998); they are barely known as fossils, and then in Palaeozoic times, from Cambrian and Carboniferous Fossil-Lagerstätten (Benton 1993; Vannier et al. 2007). However, if it is confirmed that protoconodonts are phylogenetically related to chaetognaths, and also confirmed that a phylogenetic relationship does exist between protoconodonts, paraconodonts and euconodonts (Vannier et al. 2007, and references therein), the latter would also be related to chaetognaths, rather than to chordates, a hypothesis already advocated on the basis of molecular analysis (Kasatkina \& Buryi 1996). Moreover, if conodonts are related to chaetognaths, and if the latter are the sister-group of craniates as indicated by some molecular analyses (Christofferson \& Araújo-de-Almeida 1994), this would also place conodonts in the sister-group of 
craniates (see e.g., Peterson 1994; Pridmore et al. 1997). However, the most recent molecular analysis by Putnam et al. (2008: fig. 1) placed the "hemichordate" acorn worms (i.e. Enteropneusta) + sea urchins (Echinodermata) as sister group to chordates.

Instead, we consider that conodonts s.l. represent one or more "invertebrate animals" (a paraphyletic grouping) with phosphatic elements that, unlike vertebrates, disappeared by the end of Triassic (cf. Gross 1954). A major part of the argument for excluding all conodonts from craniates (and thus from vertebrates) and not interpreting their elements as teeth rests with the differences in hard tissues (Schultze 1996; Kemp \& Nicoll 1996; Kemp e.g., 2002a, b; Reif 2006; Trotter et al. 2007).

We summarize our lines of evidence as follows: - cephalization is low in conodonts, possibly at the level of extant cephalochordates, whereas it is much higher in craniates where cephalization reaches an advanced state of development;

- conodonts lack segmentally-arranged paraxial elements, a feature of vertebrates;

- conodont trunk musculature is simple V-shaped as opposed to a W-shaped in craniates;

- conodonts lack dermal elements in median fins, whereas median fins of vertebrates possess dermal fin rays that are articulated at the base with supporting cartilaginous elements;

- conodonts lack a dermal skeleton including bony plates whereas all vertebrates have odontodes with bone of attachment and a unique pulp system (see Fig. 2 for comparative morphogenesis);

- conodont element ultrastructure, revealed by TEM and SEM, has a crystalline structure very different in crystal size and arrangement than it is in vertebrates. The albid material of conodonts is formed by extraordinarily large crystals in contrast to the fine small crystals of bone, dentine and enamel in vertebrates;

- conodont hyaline material shows a histochemical reaction for collagen, which is not present in vertebrate enamel;

- conodont element albid material (white matter) does not react for collagen, which is a major element in vertebrate bone;

- the lacunae in the albid material are too small for eukaryote cells such as osteocytes;
- a cladistic analysis based on the recoded data set of Donoghue et al. (2000) supports neither a vertebrate nor a craniate relationship for conodonts.

Above, we have summarized from the work of several of us and in addition cite new evidence. There is no evidence that conodonts share any of the attributes of vertebrate hard tissues (Trotter $e t a l$. 2007) and the morphogenetic system of formation of vertebrate hard parts (Reif 2006). Sansom (2006), in his review of Hall's (2005) book, corrected his own earlier work by stating "Conodonts did not possess cellular bone and probably did not possess cartilage within their oral-pharyngeal feeding elements, despite the interpretation of Sansom et al. (1992), a point that has become clear from later papers and a deeper understanding of the constraints of tissue topology within conodont elements".

A further paper on patterning of hair in mammals (Sick et al. 2006) reiterated the basic difference between conodonts and vertebrates - that the former have no external dermal armour whatsoever, be it isolated odontodes ("scales"), even phosphatic nubs such as in Hadimopanella (once thought to be vertebrate and now referred to palaeoscolecid worms: see e.g., Hinz et al. 1990) or bony plates. In this respect they share nothing with the earliest definite vertebrates (sensu Turner et al. 2004), either plated such as Arandaspis or scaled such as Sacabambaspis and Areyonga (Young 1997, 2009). In vertebrates, odontodes (scales, teeth, denticles, etc.; Reif 1982, 2002, 2006) grow and are shed in particular ways; only rarely is there a "continuous" growth, e.g., fin spines, rat's teeth, dicynodont and elephant tusks, but even these have a finite existence. In conodonts the elements grow outward continuously and thus are covered in soft tissue; they do not erupt and they are not shed. Because they are covered in tissue they must have been everted during feeding to function like vertebrate teeth. But, just covered by a thin tissue they could have been used for food grasping-filtering and transportation and sometimes as grinding plates (the platforms) during passage of food from the buccal cavity to the gut. This is true of the myxinoid and certain annelid/polychaete apparatuses. In myxinoids, there is the single palatal tooth attached to a cartilaginous plate. The lingual teeth also attach to a 
cartilaginous dental plate with a longitudinal keel fitting into the grooved upper surface of the immovable cartilaginous basal plate making up the floor of the mouth (Retzius 1892). The described conodont impressions lack any evidence of necessary (appropriate) cartilaginous plates, yet traces of presumed "cartilaginous" fin rays are preserved, thus arguing against similar apparatuses in conodonts and myxinoids. Of course, the limited number of possible feeding mechanisms means that any superficial similarities might as well be a matter of function as of a genetic relationship. Further, there are obvious major differences between the internal structure of phosphatic conodont elements and the horny "teeth" of myxinoids.

\section{CONCLUSIONS}

This paper constitutes a further refutation of the hypothesis that conodonts are "stem gnathostomes" or vertebrates. Conodonts are not recognized as an early vertebrate group that experimented with skeletal biomineralization. At most they might represent a cephalochordate grade of evolution, similar to the amphioxus Branchiostoma. Contra, e.g., Donoghue et al. (2000, 2003, 2008), Kuhn \& Barnes (2005), and Janvier (2008), the plesion Conodonta Eichenberg, 1930 is in no way a sister group or a member, stem or otherwise of the phylum Craniata Linnaeus, 1758, its subphylum Vertebrata Linnaeus, 1758, nor of the superclass Gnathostomata Cope, 1889. Placing higher taxa Conodontophorida or Conodonta in the Chordata Bateson, 1886 or Craniata (e.g., Farrell 2004; Nelson 2006; King et al. 2009) is not accepted for the reasons outlined above. Instead, based on the evidence provided here, we support the hypotheses that:

- the phylogenetic status of conodonts s.l., including proto-, para- and euconodonts is not resolved; at the moment the three groups are informal, with protoconodonts probably not monophyletic. Müller \& Hinz-Schallreuter (1998) considered the three groups as related. Szaniawski (2002) favoured the idea that protoconodonts belonging to the evolutionary lineage of Phakelodus are probably the stem group of chaetognaths. Szaniawski \& Bengtson
(1993) described a well documented evolutionary lineage from a paraconodont species to a euconodont species. Authors who relate euconodonts to craniates consider that the three groups have different phylogenetic relationships;

- conodont elements are not odontodes and do not possess vertebrate hard tissues, including globular cartilage, bone, lamellin, dentine, enameloid or enamel, and do not exhibit vertebrate morphogenesis (see Figs 2; 3); broken conodont elements could be repaired during the animal's life, and therefore, unlike odontodes (scales, teeth, etc.) in vertebrates, the elements had to be infolded in tissue at least at times;

- conodont elements are not homologous with vertebrate teeth and do not represent the first vertebrate experiment in skeletonisation or mineralized feeding apparatus (see Figs 2; 3);

- conodont (euconodont) animals are not craniates, nor vertebrates, nor "stem gnathostomes" (see Figs 5; 6).

\section{Acknowledgements}

We thank Dr Anne Kemp (Centre for Microscopy and Microanalysis, University of Queensland, St Lucia, Australia), and the late Dr David Carlisle (Canada), and our co-author Pr Dr Wolf-Ernst Reif (Institut für Geowissenschaften, Eberhard-Karls Universität Tübingen, IGTU), who sadly passed away in 2002 and June 2009, respectively, and Dr Robert S. Nicoll (Canberra) for their inspiration and discussion; Dr Julie Trotter (Department of Earth and Marine Sciences, Australian National University, Canberra) for sharing data whilst in press; Pr Dr Otto H. Walliser (Zentrum für Geowissenschaften, Abteilung Geobiologie, Göttingen University), Dr Rodney D. Norby (Illinois State Geological Survey, Champaign, Illinois), Dr Bruce Lieberman (University of Kansas, Department of Geology, Lawrence, Kansas), and Dr Zivile Zigaite (University of Vilnius, Lithuania) for comments on our work. Judy Bracefield (Brisbane), Verena Benz and Peter Brandscheid (IGTU) provided assistance. ST acknowledges an Australian Academy of Sciences grant, which enabled insightful discussions with and kind hospitality of Prs Drs 
W.-E. Reif and J. Nebelsick in 2006; and to the latter for support at IGTU in 2007-2009. ST and CJB acknowledge basic facilities at the Queensland Museum. We thank Drs A. Kemp, H. Lelièvre and M. Ginter, two unnamed referees, Gaël Clément and the editor-in-chief, Dr D. Merle, for their constructive reviews.

\section{REFERENCES}

Albanesi G. L. \& Bergström S. M. 2004. — Conodonts: Lower to Middle Ordovician Record, in WebBY B. D., Paris F., Droser M. L. \& Percival I. G. (eds), The Great Ordovician Biodiversity Event. Columbia University Press, New York: 312-326 + 395-466.

ALDRIDGE R. J. 1987. — Conodont palaeobiology: a historical review, in AldRIDge R. J. (ed.), Palaeobiology of conodonts. British Micropalaeontological series, Ellis Horwood: 11-34.

Aldridge R. J. \& Purnell M. A. 1996. - The conodont controversy. Trends in Ecology \& Evolution 11 (11): 463-468.

Aldridge R. J. \& BRiggs D. E. G. 2009. - The discovery of the conodont anatomy and its importance for understanding the early history of vertebrates, in Sepkoski D. \& Ruse M. (eds), The Paleobiological Revolution. Essays on the Growth of Modern Paleontology. University of Chicago Press, Chicago \& London: 73-88.

Aldridge R. J., Briggs D. E. G., Clarkson E. N. K. \& SMith M. P. 1986. - The affinities of conodonts new evidence from the Carboniferous of Edinburgh, Scotland. Lethaia 19: 279-291.

Aldridge R. J., Briggs D. E. G., SMith M. P., Clarkson E. N. K. \& Clark N. D. L. 1993. - The anatomy of conodonts. Philosophical Transactions of the Royal Society, London, Ser. B, 340: 405-421.

Andres D. 1988. - Strukturen, Apparate und Phylogenie primitiver Conodonten. Palaeontographica A 200: 105-152.

ARENDT D. \& NÜBleR-Jung K. 1994. - Inversion of dorsoventral axis. Nature 371: 26.

BALFOUR F. M. 1877. - The development of elasmobranch fishes. Journal of Anatomy and Physiology 11 (3): 406-490.

BARDACK D. 1997. - Fishes: "Agnatha", Acanthodii, and Osteichthyes, in Shabica C. W. \& Hay A. A. (eds), Richardson's Guide to The Fossil Fauna of Mazon Creek. Northeastern Illinois University, Chicago, Illinois: 226-243.

Barnes C. R., Sass D. B. \& Monroe E. A. 1973. Ultrastructure of some Ordovician conodonts, in Rhodes F. H. T. (ed.), Conodont Paleozoology. Geo- logical Society of America Special Paper 141: 1-30.

BARRY J. C. \& KEMP A. 2007. - High resolution transmission electron microscopy of developing enamel in the Australian lungfish, Neoceratodus forsteri (Osteichthyes: Dipnoi). Tissue and Cell 39: 387-398.

Barskov I. S., Moskalenko T. A. \& Sarostina L. P. 1982. - New evidence for the vertebrate nature of conodontophorids. Paleontological Journal 1982 (1): 82-90. [translation from Paleontologocheski Zhurnal 1982 (1): 80-86].

Beall B. S. 1991. - The Tully Monster and a new approach to analyzing problematica, in SIMONETTA A. M. \& CONWAY MORRIS S. (eds), The Early Evolution of Metazoa and the Significance of Problematic Taxa. Cambridge University Press, Cambridge: 271-285.

BÉLAND P. \& ARSENAULT M. 1985. — Scauménellisation de l'Acanthodii Triazeugacanthus affinis (Whiteaves) de la formation d'Escuminac (Dévonien supérieur de Miguasha, Québec) : révision du Scaumenella mesacanthi Graham-Smith. Canadian Journal of Earth Sciences 22 (4): 514-524.

BeLKa Z. 2004. — †Conodonta, in Westheide W. \& Rieger R. (eds), Spezielle Zoologie. Teil: Wirbel-oder Schädeltiere. Spektrum, Heidelberg \& Berlin: 173.

Benton M. J. (ed.) 1993. - The Fossil Record 2. Chapman \& Hall, London: XVII + 845 p.

Benton M. J. 2005. — Vertebrate Paleontology. 3rd edition. Blackwell Publishing Ltd., Oxford: XII + 474 p.

Bergström J. 1996. - Upside-down evolution? Geologiska Föreningens $i$ Stockholm Förhandlingar 118, Jubilee Issue: A58-59.

BERGSTRÖM J. 1997. - Origin of high-rank groups of organisms. Paleontological Research 1: 1-14.

Bergström J., NaumanN W. W., VieWeg J. \& MartíMus M. 1998. - Conodonts, calcichordates and the origin of vertebrates. Mitteilungen aus dem Museum für Naturkunde Berlin, Geowissenschaftliche Reihe 1: 81-92.

BERRILl N. J. 1987. — Early chordate evolution. International Journal of Invertebrate Reproduction and Development 11: 1-27.

BLIECK A. 1992. - At the origin of chordates. Geobios 25: 101-113.

Blieck A. \& Goujet D. 1983. - Zascinaspis laticephala nov. sp. (Agnatha, Heterostraci) du Dévonien inférieur du Spitsberg. Annales de Paléontologie (Vert.-Invert.) 69: 43-56.

Blieck A., Turner S., Burrow C. J., Schultze H.P. \& ReXroad C. B. 2009. - Organismal biology, phylogeny and strategy of publication: why conodonts are not vertebrates, in 69th Annual Meeting Society of Vertebrate Paleontology \& 57th Symposium on Vertebrate Palaeontology and Comparative Anatomy (SVPCA) (Univ. Bristol, UK, Sept. 23-26, 2009). Program and Abstracts. Journal of Vertebrate Paleontology 29 (Suppl. to no. 3): 65A. 
Boormann C. J. \& SHimeld S. M. 2002a. - The evolution of left-right asymmetry in chordates. BioEssays 24: 1004-1011.

Boormann C. J. \& Shimeld S. M. 2002b. - Pitx homeobox genes in Ciona and amphioxus show leftright asymmetry is a conserved chordate character and define the ascidian adenohypophysis. Evolution and Development 4: 354-365.

Bracegirdle B. \& Miles P. H. 1978. - An Atlas of Chordate Structure. Heinemann Educational Books, London, VII + 119 p.

Branson E. B. \& Mehl M. G. 1933. - Conodont studies. University of Missouri Studies 8: $349 \mathrm{p}$.

BRIGGS D. E. G. 1992. - Conodonts: A major extinct group added to the vertebrates. Science 256: 12851286.

BRIGGS D. E. G. 2003. - The role of decay and mineralization in the preservation of soft-bodied fossils. Annual Review of Earth and Planetary Sciences 31: 275-301.

Briggs D. E. G. 2010. — Decay distorts ancestry. Nature 463: 741-743.

Briggs D. E. G., Clarkson E. N. K. \& Aldridge R. J. 1983. - The conodont animal. Lethaia 16: 1-14.

BRiggs D. E. G., Aldridge R. J. \& SMITH M. P. 1987. Conodonts are not aplacophoran molluscs. Lethaia 20: 381-382.

BultyncK P. 1987. - Pelagic and neritic conodont successions from the Givetian of pre-Sahara Morocco and the Ardennes. Bulletin de l'Institut royal des Sciences naturelles de Belgique, Sciences de la Terre 57: 149-181.

BULTYNCK P. 2009. - To be or not to be: can conodonts be vertebrates?, in P. GODEFROIT \& O. LAMBERT (eds), EAVP Extraordinary Meeting - Tribute to Charles Darwin and Bernissart Iguanodons (Brussels, 9-14 Febr. 2009). Royal Institute of Natural Sciences of Belgium, Brussels: 24.

CARLISLE D. B. 1953. - On the origin of the pituitary body of chordates. Nature 172: 1098 .

CARLSON S. J. 1990. - Vertebrate dental structures (chapter 21), in CARTER J. G. (ed.), Skeletal Biomineralization: Patterns, Processes and Evolutionary Trends. Volume I. Van Nostrand Reinhold, New York: 531-556.

Carter J. G. \& Lutz R. A. 1990. - Bivalvia (Mollusca), in CARTER J. G. (ed.), Skeletal Biomineralization: Patterns, Processes and Evolutionary Trends. Volume II. Part 2 Atlas and Index. Van Nostrand Reinhold, New York: 5-28, pls 1-121.

Chen J.-Y., DZIK J., EdGeCombe G. D., RAmSKÖld L. \& ZHOU G.-Q. 1995. - A possible Early Cambrian chordate. Nature 377: 720-722.

Chen J.-Y., Huang D.-Y. \& Li C.-W. 1999. - An early Cambrian craniate-like chordate. Nature 402: 518-522.
Christofferson M. L. \& Araújo-de-Almeida E. A. 1994. - A phylogenetic framework of the enterocoela (Metamerie: Coelomata). Revista Norestina de Biologia (Brazil) 9: 172-208.

ClarKSON E. N. K. 1985. - 1. The Granton Shrimp-Bed, Edinburgh: crustaceans, conodonts and conservation. Earth Science Conservation 22: 3-8.

CONWAY MORRIS S. 1989. — Conodont palaeobiology: recent progress and unsolved problems. Terra Nova 1: $135-150$.

CONWAY MORRIS S. 1991. — Problematic taxa: a problem for biology or biologists?, in SiMONETTA A. M. \& CONWAY MORRIS S. (eds), The Early Evolution of Metazoa and the Significance of Problematic Taxa. Cambridge University Press: 19-24.

CONWAY MORRIS S. 1993a. - The fossil record and the early evolution of the Metazoa. Nature 361 (6409): 219-225.

CONWAY MORRIS S. 1993b. - Ediacaran-like fossils in Cambrian Burgess Shale-type faunas of North America. Palaeontology 36 (3): 593-635.

CONWAY MORRIS S. 1998. - The Crucible of Creation. The Burgess Shale and the Rise of Animals. Oxford University Press, Oxford: XXIII + 242 p.

Costa O. G. 1834. - Annuario zoologico. Cenni zoologici, ossia descrizione sommaria delle specie nuove di animali discoperti in diverse contrade del regno nell' anno 1834. Napoli, 99 p.

DEAN B. 1899. - On the embryology of Bdellostoma stouti, in Festschrift zum siebenzigsten Geburtstag von Carl F. v. Kuppfer. Gustav Fischer, Jena: 221-276.

DeAn M. N. \& Summers A. P. 2006. - Mineralized cartilage in the skeleton of chondrichthyan fishes. Zoology 109: 164-168.

DENISON R. H. 1967. — Ordovician vertebrates from Western United States. Fieldiana: Geology 16 (6): 131-192.

DixOn A. D., HoyTe D. A. N. \& RÖNNING O. 1988. Fundamentals of Craniofacial Growth. CRC Press, New York, $487 \mathrm{p}$.

Dong X.-P., Donoghue P. C. J. \& Repetski J. E. 2005. - Basal tissue structure in the earliest euconodonts: Testing hypotheses of developmental plasticity in euconodont phylogeny. Palaeontology 48 (2): 411-421.

DoNOGHUE P. C. J. 1998. — Growth and patterning in the conodont skeleton. Philosophical Transactions of the Royal Society of London, Series B, 353: 633-666.

Donoghue P. C J. 2001. - Microstructural variation in conodont enamel is a functional adaptation. Proceedings of the Royal Society of London, Series B, 268: 1691-1698.

Donoghue P. C. J. 2005. - Saving the stem group - a contradiction in terms? Paleobiology 31 (4): 553558.

Donoghue P. C. J. \& Chauffe K. 1998. — Concho- 
dontus, Mitrellataxis and Fungulodus: conodonts, fish, or both? Lethaia 31: 283-292.

Donoghue P. C. J. \& Aldridge R. J. 2001. — Origin of a mineralized skeleton, in AHLBERG P. E. (ed.), Major Events in Early Vertebrate Evolution - Palaeontology, phylogeny, genetics and development. Systematics Association, Special Volume Series 61. Taylor \& Francis, London \& New York: 85-105.

Donoghue P. C. J. \& SAnsom I. J. 2002. - Origin and Early Evolution of Vertebrate Skeletonization. Microscopy Research and Technique 59: 352-372.

Donoghue P. C. J. \& Purnell M. A. 2005. — Genome duplication, extinction and vertebrate evolution. Trends in Ecology and Evolution 20 (6): 312-319.

Donoghue P. C. J., Purnell M. A. \& Aldridge R. J. 1998. - Conodont anatomy, chordate phylogeny and vertebrate classification. Lethaia 31 (3): 211-219.

Donoghue P. C. J., Forey P. L. \& Aldridge R. J. 2000. - Conodont affinity and chordate phylogeny. Biological Reviews 75: 191-251.

Donoghue P. C. J., Smith M. P. \& Sansom I. J. 2003. - The origin and early evolution of chordates: molecular clocks and the fossil record, in DONOGHUE P. C. J. \& SMITH M. P. (eds), Telling the Evolutionary Time: Molecular Clocks and the Fossil Record. Taylor \& Francis, London \& New York: 190-223.

Donoghue P. C. J., SANSOM I. J. \& Downs J. P. 2006. Early evolution of vertebrate skeletal tissues and cellular interactions, and the canalization of skeletal development. Journal of Experimental Zoology 306B: 278-294.

Donoghue P. C. J., Purnell M. A., Aldridge R. J. \& Zhang S.-X. 2008. - The interrelationships of "complex" conodonts (Vertebrata). Journal of Systematic Palaeontology 6 (2): 119-153.

DZIK J. 1986. - Chordate affinities of the conodonts, in Hoffmann A. \& Nitecki M. (eds), Problematic Fossil Taxa. Oxford Monographs on Geology and Geophysics no. 5. Oxford University Press, Oxford, New York: 240-254.

DZIK J. 2000. - The origin of the mineral skeleton in chordates, in HeCHT M. K., MacintyRe R. J. \& Clegg M. T. (eds), Evolutionary Biology. volume 31. Kluwer Academic; Plenum Publisher, New York: $105-154$.

DZIK J. 2009. - Conodont affinity of the enigmatic Carboniferous chordate Conopiscius. Lethaia 41: 31-38.

FÅnRAeUs L. E. \& FÅhraeUS-VON ReE G. E. 1994. Histomorphology of sectioned and stained $415 \mathrm{Ma}$ old soft-tissue matrix from internal fluorapatite skeletal elements of an extinct taxon, Conodontophorida (Conodonta), in KobaYAshi I., MutveI H. \& SAHNi A. (eds), Structure, Formation and Evolution of Fossil Hard Tissues. Tokyo University Press, Tokyo: 107-112.
FARRELL J. R. 2004. — Siluro-Devonian conodonts from the Camelford Limestone, Wellington, New South Wales. Palaeontology 47: 937-982.

Francillon-Vieillot H., BufFrenil V. DE, CASTANET J., Geraudie J., Meunier F. J., Sire J.-Y, ZylberBERG L. \& RICQLES A. DE 1990. - Microstructure and mineralization of vertebrate skeletal tissues, in CARTER J. G. (ed.), Skeletal Biomineralization. Van Norstrand, New York: 471-530.

FuRNISH W. M. 1938. — Conodonts from the Prairie du Chien (Lower Ordovician) beds of the upper Mississippi valley. Journal of Paleontology 12: 318-340.

GABBOTT S. E., AldRidge R. J. \& THERON J. N. 1995. A giant conodont with preserved muscle tissue from the Upper Ordovician of South Africa. Nature 374 (6525): 800-803.

GARSTANG W. 1928. - The origin and evolution of larval forms. Nature 211: 366.

GediK I. V. \& ÇAPKINOGLU S. 1996. - Conodonts, were they (the first?) parasitic animals?, in Sixth International Conodont Symposium (ECOS VI, July 4-6, 1996, Warszawa). Abstracts: 19.

Gess R. W., Coates M. I. \& Rubidge B. S. 2006. A lamprey from the Devonian of South Africa. Nature 443: 981-984.

Gross W. 1954. - Zur Conodonten-Frage. Senckenbergiana lethaea 35 (1/2): 73-85.

Gross W. 1957. — Über die Basis der Conodonten. Paläontologische Zeitschrift 31: 78-91.

Gross W. 1960. — Über die Basis bei den Gattungen Palmatolepis und Polygnathus (Conodontida). Paläontologische Zeitschrift 34: 40-58.

GuO W., DONG X.-P., ZenG X.-C. \& ZHAO L. 2005. Histological observation of some primitive euconodonts of Late Cambrian from Liaoning. Progress in Natural Science 15 (12): 1084-1088.

HaLl B. K. 2005. - Bones and Cartilage: Developmental and Evolutionary Skeletal Biology. Elsevier Academic Press, San Diego: XXXVII + 760 p.

Hall J. C. 1990. - Conodontophorida, in CARTER J. G. (ed.), Skeletal Mineralization: Patterns, Processes and Evolutionary Trends. Volume II. Part 10 Atlas and Index. Van Nostrand Reinhold, New York: 81-85.

Hardisty A. \& Potter I. (eds) 1972. — The Biology of Lampreys. Volume 2. Academic Press, New York, $\mathrm{XIV}+466 \mathrm{p}$.

HASS W. H. 1941. - The morphology of conodonts. Journal of Paleontology 15: 71-81.

HeNnig W. 1969. - Die Stammesgeschichte der Insekten. W. Kramer, Frankfurt/Main, Senckenberg-Buch 40, $436 \mathrm{p}$.

HENNIG W. 1983. - Stammesgeschichte der Chordaten. Fortschritte in der zoologischen Systematik und Evolutionsforschung 2. P. Parey, Hamburg, Berlin, 208 p.

HindE G. J. 1879. - On conodonts from the Chazy and Cincinnati Group of the Cambro-Silurian, and 
from the Hamilton and Genesee-Shale division of the Devonian, in Canada and the United States. Quarterly Journal of the Geological Society, London 35: 351-369.

Hinz, I., Kraft, P., Mergl, M. \& MÜller, K. J. 1990. The problematic Hadimopanella, Kaimenella, Milaculum and Utahphospha identified as sclerites of Palaeoscolecida. Lethaia 23: 217-221.

Holland L. Z. \& Holland N. D. 2001. — Evolution of neural crest and placodes: amphioxus as a model for the ancestral vertebrate? Journal of Anatomy 199: 85-98.

Holland N. D. \& Chen J.-Y. 2001. - Origin and early evolution of the vertebrates: new insights from advances in molecular biology, anatomy, and palaeontology. BioEssays 23: 142-151.

Hou X.-G., Aldridge R. J., Siveter D. J., Siveter D. J. \& FENG X.-H. 2002. - New evidence of the anatomy and phylogeny of the earliest vertebrates. Proceedings of the Royal Society, London B 269: 18651869.

HuXLEY T. H. 1858. - On the theory of the vertebrate skull. Croonian Lecture delivered 18 November, 1858. Proceedings of the Royal Society, London 9: 381-457 [imprint 1859].

HuysSEune A., Sire J.-Y. \& WitTen P. E. 2009. — Evolutionary and developmental origins of the vertebrate dentition, in The Integument Story: Origins, Evolution and Current Knowledge (Paris, July 2007). Journal of Anatomy 214 (4): 465-476.

JANVIER P. 1981. - The phylogeny of the Craniata, with particular reference to the significance of fossil "agnathans". Journal of Vertebrate Paleontology 1(2): 121-159.

JanVier P. 1997. - Euconodonta, in Tree of Life. World Wide Web address: http://www.tolweb.org/ Euconodonta/14832 (accessed 2009).

Janvier P. 1998. — Les Vertébrés avant le Silurien. Geobios 30 (7): 931-950.

JANVIER P. 2001. - Euconodonta†, in Tree of Life. World Wide Web address: http://phylogeny.Arizona. edu/tree/eukaryotes/animals/chordata/euconodonta/ (accessed 2009).

JANVIER P. 2003. - Vertebrate characters and the Cambrian vertebrates, in NÉRAUDEAU D. (ed.), Les chemins de l'évolution: sur les pas de Steven Jay Gould. ComptesRendus Palevol 2 (6-7): 523-531.

JANVIER P. 2006. - Modern look for ancient lamprey. Nature 443: 921-924.

JanVIER P. 2007a. — Living primitive fishes and fishes from deep time, in MCKenZie D. J., Farrel A. P. \& Brauner C. J. (eds), Primitive Fishes. Fish Physiology 26. Elsevier, Amsterdam: 1-51.

JANVIER P. 2007b. - Homologies and evolutionary transitions in early vertebrate history, in ANDERSON J. S. \& SUES H.-D. (eds), Major Transitions in Vertebrate
Evolution. Indiana University Press, Bloomington and Indianapolis: 57-121.

JanVier P. 2008. - The brain in the early jawless vertebrates: evolutionary information from an empty nutshell. Brain Research Bulletin 75: 314-318.

JANVIER P. 2009. — Les premiers Vertébrés et les premières étapes de l'évolution du crâne, in COPPENS Y., PAdian K., De Ricqlès A. \& Taquet P. (eds), Histoire évolutive de la vie. Comptes-Rendus Palevol 8 (2-3): 209-219.

JanVier P. \& Lund R. 1983. - Hardistiella montanensis n. gen. et sp. (Petromyzontida) from the Lower Carboniferous of Montana with remarks on the affinities of the lampreys. Journal of Vertebrate Paleontology 2: 407-413.

JanVIER P. \& ARSENAUlT M. 2007. - The anatomy of Euphanerops longaevus Woodward, 1900, an anaspidlike jawless vertebrate from the Upper Devonian of Miguasha, Quebec, Canada. Geodiversitas 29 (1): 143-216.

JEFFERIES R. P. S. 1979. — The origin of chordates - a methodological essay, in House M. R. (ed.), The Origin of Major Invertebrate Groups. Systematics Association, Special Volume 12. Academic Press, London: 443-477.

JEFFERIES R. P. S. 2001. - The origin and early fossil history of the chordate acustico-lateralis system, with remarks on the reality of the echinoderm-hemichordate clade, in AhlBerg P. E. (ed.), Major Events in Early Vertebrate Evolution - Palaeontology, Phylogeny, Genetics and Development. Systematics Association, Special Volume Series 61. Taylor \& Francis, London \& New York: 40-66.

Kasatkina A. P. \& Buryi G. I. 1996. — On the relation of chaetognaths and conodonts. Albertiana 18: 21-23.

KAWASAKI K., SuZUKI T. \& WeisS K. M. 2004. - Genetic basis for the evolution of vertebrate mineralized tissue. Proceedings of the National Academy of Sciences 101 (31): 11356-11361.

KEMP A. 1992. - Ultrastructure of the developing dentition in the Australian lungfish, Neoceratodus forsteri, in SMITH P. \& TCHERNOV E. (eds), Structure, Function and Evolution of Teeth. Freund Publisher, Tel Aviv: 11-33.

KEMP A. 1999. - A refined method for the staining of organic remnants in conodont elements. Ichthyolith Issues 20: 34.

KEMP A. 2002a. - Hyaline tissue of thermally unaltered conodont elements and the enamel of vertebrates. Alcheringa 26: 23-36.

Kemp A. 2002b. - Amino-acid residues in conodont elements. Journal of Paleontology 76: 518-528.

KEMP A. 2003. - Ultrastructure of developing tooth plates in the Australian lungfish. Neoceratodus forsteri (Osteichthyes: Dipnoi). Tissue and Cell 35: 
401-426.

KemP A. \& Nicoll R. S. 1995. - Protochordate affinities of conodonts. Courier Forschungsinstitut Senckenberg 182: 235-245.

Kemp A. \& Nicoll R. S. 1996. - A histochemical analysis of biological residues in conodont elements, in Turner S. \& BliecK A. (eds), Gross Symposium, Volume 1. Modern Geology 20 (3-4): 287-302 (republished in Turner S. \& Blieck A. [eds], Gross Symposium, Volume 2. Modern Geology 21 [1-2]: 197-213 with 2 colour plates [1997]).

Kemp A. \& BARrY J. C. 2006. - Prismatic dentine in the Australian lungfish, Neoceratodus forsteri (Osteichthyes: Dipnoi). Tissue and Cell 38: 127-140.

King C. M., Roberts C. D., Bell B. D., Fordyce R. E., Nicoll R. S., Worthy T. H., Paulin C. D., Hitchmough R. A., Keyes I. W., Baker A. N., Stewart A. L., Hiller N., McDowall R. M., Holdaway R. N., McPheE R. P., SChWARZhans W. W., Tennyson A. J. D., Rust S. \& MACAdie I. 2009. - Chapter 24: Phylum Chordata - lancelets, fishes, amphibians, reptiles, birds, mammals, in GORDON D. P. (ed.), New Zealand Inventory of Biodiversity. Vol. One: Kingdom Animalia. Canterbury University Press, Christchurch: 433-553.

KOENIGSWALD W. v. 2000. - Two different strategies in enamel differentiation: Marsupialia versus Eutheria, in Teaford M. F., SMith M. M. \& Ferguson M. W. J. (eds), Development, Function and Evolution of Teeth. Cambridge University Press, Cambridge, UK: $107-118$.

KoENTGES G. 2008. - Teeth in double trouble. Nature 455: 747-748.

Kunn T. S. \& Barnes C. R. 2005. - Ordovician conodonts from the Mithaka Formation (Georgina Basin, Australia): regional and paleobiogeographical implications. Geologica Acta 3 (4): 317-337.

LAURIN M. \& ANDERSON J. S. 2004. - Meaning of the name Tetrapoda in the scientific literature: an exchange. Systematic Biology 53: 68-80 .

LeCOINTRE G. \& LE GUYADER H. 2001. - Classification phylogénétique du Vivant. Belin, Paris, 543 p. (translated to English: The Tree of Life: A Phylogenetic Classification. Harvard University Press, Cambridge, Massachusetts, 2006)

Liem K. F., Bemis W. E., Walker W. F. J. \& Grande L. 2001. - Functional Anatomy of the Vertebrates: an Evolutionary Perspective. Third edition. Harcourt College Publishers, Orlando, Florida: XVII + 703 p.

LiNDSTRÖM M. 1964. - Conodonts. Elsevier, Amsterdam, VI + $196 \mathrm{p}$.

LiNDSTRÖM M. \& ZiegLER W. 1971. — Feinstrukturelle Untersuchungen an Conodonten. 1. Die Überfamilie Panderodontacea. Geologica et Palaeontologica 5: 9-33.

LINDSTRÖM M. \& ZIEGLER W. 1981. — Surface micro- ornamentation and observations on internal composition, in Robison R. A. (ed.), Treatise on Invertebrate Paleontology, Part W: Miscellanea, Supplement 2, Conodonta. Geological Society of America and University of Kansas, Lawrence: W41-W52.

Mallatt J. \& ChEn J.-Y. 2003. — Fossil sister group of craniates: predicted and found. Journal of Morphology 258: 1-31.

MARINELLI W. \& STRENGER A. 1954. - Vergleichende Anatomie und Morphologie der Wirbeltiere. Band 1. II. Lieferung: Lampetra fluviatilis (L.). Franz Deuticke, Wien: $1-80$.

Marinelli W. \& Strenger A. 1956. - Vergleichende Anatomie und Morphologie der Wirbeltiere. Band 1. II. Lieferung: Myxine glutinosa (L.). Franz Deuticke, Wien: 81-172.

MÄRSS T. 2006. - Exoskeletal ultrasculpture of early vertebrates. Journal of Vertebrate Paleontology 26 (2): 235-252.

Märss T., Turner, S. \& Karatajute-TalimaA, V. N. 2007. - "Agnatha" II, Thelodonti, in SCHULTZE H.-P. (ed.), Handbook of Paleoichthyology, Vol. 1B. Verlag Dr Friedrich Pfeil, Munich, 143 p.

Moser H. G., Richards W. J., Cohen D. M., Fahay M. P., Kendall A. W. Jr \& Richardson S. L. (eds) 1984. - Ontogeny and Systematics of Fishes. American Society of Ichthyologists and Herpetologists, Special Publication Number 1: IX + 760 p.

MÜLlER K. J. 1981. - Zoological affinities of conodonts, in ROBISON, R. A. (ed.), Treatise on Invertebrate Palaeontology, Part W: Miscellanea, Supplement 2, Conodonta. Geological Society of America, University of Kansas, Lawrence: W78-W82.

MÜller K. J. \& Nogami Y. 1971. — Über den Feinbau der Conodonten. Memoirs of the Faculty of Sciences Kyoto University, Series of Geology and Mineralogy 38: 1-88.

MÜller K. J. \& Hinz I. 1991. — Upper Cambrian conodonts from Sweden. Fossils and Strata 28: 153 p.

Müller K. J. \& Hinz-Schallreuter I. 1998. - Internal structure of Cambrian conodonts. Journal of Paleontology 72 (1): 91-112.

Nelson J. S. 2006. - Fishes of the World. 4th Edition. John Wiley \& Sons Inc., Hoboken, XIX + 601 p.

NICOLL R. S. 1985. - Multielement composition of the conodont species Polygnathus xylus xylus Stauffer, 1940 and Ozarkodina brevis (Bischoff and Ziegler, 1957) from the Upper Devonian of the Canning Basin Western Australia. BMR Journal of Australian Geology and Geophysics 9: 133-147.

NiCOLL R. S. 1987. - Form and function of the Pa element in the conodont animal, in ALDRIDGE R. J. (ed.), Palaeobiology of Conodonts. Ellis Horwood, Chichester: 77-90.

NiCOLL R. S. 1992. - Analysis of conodont apparatus organisation and the genus Jumudontus (Conodonta), 
a coniform-pectiniform apparatus structure from the Early Ordovician. BMR Journal of Australian Geology and Geophysics 13: 213-228.

NICOLL R. S. 1995. — Conodont element morphology, apparatus reconstruction and element function: a new interpretation of conodont biology with taxonomic implications. Courier Forschungsinstitut Senckenberg 182: 247-262.

NORBY R. D. 1976. - Conodont apparatuses from Chesterian (Mississippian) strata of Montana and Illinois. Unpublished PhD Thesis, University of Illinois at Champaign-Urbana, USA, 203 p.

NorTHCUTT R. G. 1996. - The origin of craniates: neural crest, neurogenic placodes, and homeobox genes. Israel Journal of Zoology 42: 273-313.

Oelofsen B. W. \& LoOCK J. C. 1981. — A first record of a fossil cephalochordate. Palaeontographia Africana 24: 17 .

ØRVIG T. 1973. - Fossila fisktänder i svepelektronmikroskopet: gamla frågesställningar i ny belysning [Fossil fish teeth in the scanning electron microscope: old problems in new light]. Flora och Fauna 68(4): 166-173 (in Swedish).

Ota K. G., Kuraku S. \& Kuratani S. 2007. - Hagfish embryology with reference to the evolution of the neural crest. Nature 446: 672-675.

PAgE R. D. M. 1996. - Treeview: an application to display phylogenetic trees on personal computers. Computer Applications in the Biosciences 12:357-358. Also World Wide Web address: http://taxonomy.zoology.gla.ac.uk/rod/treeview.html (accessed 2009).

Page R. D. M. 1999. - Nexus Data Editor for Windows. World Wide Web address: http://taxonomy.zoology. gla.ac.uk/rod/NDE/nde.html (accessed 2009).

PANDER C. H. 1856. - Monographie der fossilen Fische des silurischen Systems der russisch-baltischen Gouvernements. Kaiserliche Akademie der Wissenschaften, St. Petersburg, X + 91 p.

Paris M., Escriva H., Schubert M., Brunet F., BrtKo J., Ciesielski F., Roecklin D., Vivat-Hannah V., Jamin E. L., CRAVEDI J.-P., SCANLAN T. S., RENAUd J.-P., Holland N. D. \& Laudet V. 2008. - Amphioxus postembryonic development reveals the homology of chordate metamorphosis. Current Biology 18: 825-830.

Parker T. J. \& Haswell W. A. 1921. - A Text-Book of Zoology. Vol. II. Macmillan and Co., London, $\mathrm{XX}+714 \mathrm{p}$.

Pernègre V. \& Goujet D. 2007. — The genus Gigantaspis Heintz, 1962 (Vertebrata, Heterostraci) from the Lower Devonian of Spitsbergen. Palaeontology 50: 323-346.

PETERSON K. J. 1994. - The origin and early evolution of the Craniata, in Prothero D. R. \& SCHOCH R. M. (eds), Major features of vertebrate evolution. The Paleontological Society, Short Courses in Paleontology
7: 14-37.

Poplin C., Sotty D. \& Janvier P. 2001. — Un Myxinoïde (Craniata, Hypertreti) dans le Konservat-Lagerstätte Carbonifere supérieur de Montceau-les-Mines (Allier, France). Comptes-rendus de l'Académie des Sciences, Paris, Sciences de la Terre et des planètes 332: 345-350.

PRIDMORE P. A., BARWICK R. E. \& NiCOll R. S. 1997. Soft anatomy and the affinities of conodonts. Lethaia 29 (4): 317-328.

Prothero D. R. 1998. - Bringing Fossils to Life. An Introduction to Paleobiology. WCB McGraw-Hill, Boston, X+ $457 \mathrm{p}$.

Purnell M. A. 1993. - Feeding mechanisms in conodonts and the function of the earliest vertebrate hard tissues. Geology 21: 375-377.

PuRnell M. A. 1995a. - Microwear on conodont elements and macrophagy in the first vertebrates. Nature 374 (6525): 798-800.

Purnell M. A. 1995b. - Large eyes and vision in conodonts. Lethaia 28: 187-188.

Purnell M. A. 2001. - Scenarios, selection, and the ecology of early vertebrates, in AHLBERG P. E. (ed.), Major Events in Early Vertebrate Evolution. Palaeontology, Phylogeny, Genetics and Development. Systematics Association Special Volume Series 61. Taylor \& Francis, London and New York: 188-208.

Purnell M. A. \& VON BitTer P. 1992. — Blade-shaped conodont elements functioned as cutting teeth. $\mathrm{Na}$ ture 359: 629-630.

Putnam N. H., Butts T., Ferrier D. E. K., Furlong R. F., Hellsten U., KaWAshima T., Robinson-RechaVI M., Shoguchi E., Terry A., Yu J.-K., BenitoGutiérrez E., DubchaK I., Garcia-Fernández J., Gibson-Brown J. J., Grigoriev I. V., HorTON A. C., Jong P. J. DE, JuRka J., Kapitonov V. V., Kohara Y., KUROKI Y., LindQUist E., LuCAS S., Osoegawa K., Pennacchio L. A., Salamov A. A., Satou Y., Sauka-Spengler T., Schmutz J., Shin-I T., Toyoda A., Bronner-Fraser M., Fujiyama A., Holland L. Z., Holland P. W. H., Satoh N. \& ROKHSAR D. S. 2008. - The amphioxus genome and the evolution of the chordate karyotype. Nature 453: 1064-1071.

RAINERI M. 2006. - Are protochordates chordates? Biological Journal of the Linnean Society, London, 87 (2): 261-284 (with Erratum: Biological Journal of the Linnean Society, London, 87 [4]: 637 [2006]).

REIF W.-E. 1982. - Evolution of dermal skeleton and dentition in vertebrates. The Odontode Regulation Theory, in Hecht M., Wallace B. \& Prance G. T. (eds), Evolutionary Biology 15. Plenum Press, New York: 287-368.

ReIF W.-E. 1984. — Pattern regulation in shark dentition, in Malachinski G. M. (ed.), Pattern Formation, a Primer in Developmental Biology. Macmillan 
Publishing Co., New York, 603-621.

REIF W.-E. 2002. - Evolution of the dermal skeleton of vertebrates: Concepts and methods. Neues Jahrbuch für Geologie und Paläontologie, Abhandlungen 223 (1): 53-78.

REIF W.-E. 2004. — Problematic issues of cladistics: 5. Flexible phylogenetic classification (FPC) of higher taxa of the Vertebrata. Neues Jahrbuch für Geologie und Paläontologie, Abhandlungen 233 (3): 369-395.

REIF W.-E. 2006. - Conodonts, odontodes, stem-groups, and the ancestry of enamel genes. Neues Jahrbuch für Geologie und Paläontologie, Abhandlungen 241 (3): 405-439.

Retzius M. G. 1892. - Das Caudalskelet der Myxine glutinosa. Biologiska Föreningen i Förhandlingar, Stockholm 3: 81-84.

SANDER P. M. 1997. - Non-mammalian synapsid enamel and the origin of mammalian enamel prisms: The bottom-up perspective, in KOENIGSWALD W. VON \& SANDER P. M. (eds), Tooth Enamel Microstructure. AA Balkema, Rotterdam: 41-62.

SANDER P. M. 2000. - Prismless enamel in amniotes: terminology, functions, and evolution, in TEAFORD M. F., Smith M. M. \& Ferguson M. W. J. (eds), Development, Function and Evolution of Teeth. Cambridge University Press, Cambridge, UK: 92-106.

SANSOM I. J. 2006. - Book Review. Bones and Cartilage: Developmental and Evolutionary Skeletal Biology. Brian K. Hall. 2005. Elsevier Academic Press, San Diego. xxxviii+760 pp., with illustrations. Evolution \& Development 8 (4): 389-390.

Sansom I. J., Smith M. P., ARMSTRONG H. A. \& SMith M. M. 1992. - Presence of the earliest vertebrate hard tissues in conodonts. Science 256: 1308-1311.

Sansom I. J., Smith M. M. \& SMith M. P. 1994. Dentine in conodonts. Nature 368: 591.

Sansom I. J., Smith M. M. \& Smith M. P. 2001. The Ordovician radiation of vertebrates, in AHLBERG P. E. (ed.), Major Events in Early Vertebrate Evolution. Palaeontology, Phylogeny, Genetics and Development. Systematics Association, Special Volume Series 61. Taylor \& Francis, London and New York: 156-171.

Sansom I. J., Donoghue P. C. J. \& Albanesi G. 2005. Histology and affinity of the earliest armoured vertebrate. Biology Letters 1 (4): 446-449.

Sansom R. S., GabBott S. E. \& PuRnell M. A. 2010. Non-random decay of chordate characters causes bias in fossil interpretation. Nature 463: 797-800.

Satchell P. G., Shuler C. F. \& Diekwisch T. G. H. 2000. - True enamel coverings in teeth of the Australian lungfish Neoceratodus forsteri. Cell and Tissue Research 299: 27-37.

SCHÄFER W. 1972. - Ecology and Paleoecology of the Marine Environment. Oliver and Boyd, Edinburgh, $568 \mathrm{p}$.

SCHMidT H. \& MÜller K. J. 1964. — Weitere Funde von Conodonten-Gruppen aus dem oberen Karbon des Sauerlandes. Paläontologische Zeitschrift 38: 105-135.

Schultze H.-P. 1969. — Die Faltenzähne der rhipidistiiden Crossopterygier, der Tetrapoden und der Actinopterygier-Gattung Lepisosteus; nebst einer Beschreibung der Zahnstruktur von Onychodus (struniiformer Crossopterygier). Palaeontographica Italica 65 (n. ser. 35): 63-137.

SChultze H.-P. 1996. — Conodont histology: an indicator of vertebrate relationship?, in TURNER S. \& BlieCK A. (eds), Gross Symposium, Volume 2. Modern Geology 20 (3-4): 275-285.

SHimeld S. M. \& Holland P. W. H. 2000. - Vertebrate innovations. Proceedings of the National Academy of Sciences of the United States of America 97 (9): 4449-4452.

Shu D.-G., Conway Morris S., Han J., Zhang Z.-F., Yasui K., Janvier P., Chen L., Zhang X.-L., LiU J.-N., LI Y. \& LIU H.-Q. 2003. — Head and backbone of the Early Cambrian vertebrate Haikouichthys. Nature 421 (6922): 526-529.

SHu D.-G., CONWAY Morris S. \& ZHANG X.-L. 1996a. A Pikaia-like chordate from the Lower Cambrian of China. Nature 384: 156-157.

SHu D.-G., ZHANG X.-L. \& CHEN L.-Z. 1996b. - Reinterpretation of Yunnanozoon as the earliest known hemichordate. Nature 380: 428-430.

Shu D.-G., LuO H.-L., CONWAY MORris S., ZHANG X.-L., Hu S.-X., Chen L., Han J., Zhu M., Li Y. \& CHEN L.-Z. 1999. - Lower Cambrian vertebrates from South China. Nature 402 (6757): 42-46.

Sick S., ReinKer S., Timmer J. \& SChlaKe T. 2006. WNT and DKK determine hair follicle spacing through a reaction-diffusion mechanism. Science 31: 1447-1450.

Simonetta A. M., Pucci A. \& Dzik J. 1999. - Hypotheses on the origin and early evolution of chordates in the light of recent zoological and paleontological evidence. Italian Journal of Zoology 66: 99-109.

Sire J.-Y., Donoghue P. C. J. \& Vickaryous M. K. 2009. - Origin and evolution of the integumentary skeleton in non-tetrapod vertebrates. Journal of Anatomy 214 (4): 409-440.

SMITH M. M. 1989. - Distribution and variation in enamel structure in the oral teeth of sarcopterygians: its significance for the evolution of a protoprismatic enamel. Historical Biology 3: 97-126.

Smith M. P., Briggs D. E. G. \& Aldridge R. J. 1987. — A conodont animal from the lower Silurian of Wisconsin, USA, and the apparatus architecture of panderodontid conodonts, in Aldridge R. J. (ed.), Palaeobiology of conodonts. British Micropalaeontological Society Series, Ellis Horwood, Chichester: 91-104.

Smith M. M., Sansom I. J. \& Smith M. P. [quoted as Smith P.] 1995. — Diversity of the dermal skeleton 
in Ordovician to Silurian vertebrate taxa from North America: histology, skeletogenesis and relationships, in Lelièvre H., Wenz S., Blieck A. \& Cloutier R. (eds), Premiers Vertébrés et Vertébrés Inférieurs. Geobios, Mémoire Spécial 19: 65-70.

Smith M. M., Sansom I. J. \& Smith M. P. 1996. "Teeth" before armour: the earliest vertebrate mineralized tissues, in Turner S. \& BliECK A. (eds), Gross Symposium, Volume I. Modern Geology 20 (3-4): 303-319.

Smith M. P., Sansom I. J. \& Cochrane K. D. 2001. The Cambrian origin of vertebrates, in AHLBERG P. E. (ed.), Major Events in Early Vertebrate Evolution. Palaeontology, Phylogeny, Genetics and Development. Systematics Association, Special Volume Series 61. Taylor \& Francis, London and New York: 67-84.

SWEET W. C. 1981. - Morphology and composition of elements- Macromorphology of elements and apparatuses, in ROBISON R. A. ( ed.), Treatise on Invertebrate Paleontology, Part W, Miscellanea, Supplement 2, Conodonta. Geological Society of America and University of Kansas, Lawrence: W5-W20.

SweET W. C. 1988. - The Conodonta: Morphology, Taxonomy, Paleoecology, and Evolutionary History of a Long-extinct Animal Phylum. Oxford Monographs on Geology and Geophysics 10. Clarendon Press, Oxford, $\mathrm{x}+212 \mathrm{p}$.

SWOFFORD D. 2002. - PAUP 4.0b10 for Windows. Sinauer Associates, Sunderland, Massachusetts. World Wide Web address: http://paup.csit.fsu.edu/win. html.

SZANIAWSKI H. 1983. - Structure of protoconodont elements. Fossils and Strata 15: 21-27.

SZANIAWSKI H. 1987. — Preliminary structural comparisons of protoconodont, paraconodont, and euconodont elements, in Aldridge R. J. (ed.), Palaeobiology of Conodonts. Ellis Horwood, Chichester: 35-47.

SZANIAWSKI H. 2002. - New evidence for the protoconodont origin of chaetognaths. Acta Palaeontologica Polonica 47 (3): 405-419.

SZANIAWSKI H. \& BengTSON S. 1993. - Origin of euconodont elements. Journal of Paleontology 67 (4): 640-654.

Tillier S. \& CUif J.-P. 1986. — L'animal-conodonte est-il un Mollusque Aplacophore? Comptes-rendus de l'Académie des Sciences, Paris 303 (II): 627-632.

Trotter J. A. \& Eggins S. M. 2006. - Chemical systematics of conodont apatite determined by laser ablation ICPMS. Chemical Geology 233: 196-216.

Trotter J. A., Gerald J. D. F., KoKKOnen H. \& Barnes C. R. 2007. - New insights into the ultrastructure, permeability, and integrity of conodont apatite determined by transmission electron microscopy. Lethaia 40 (2): 97-110.

TURNER S. 1985. - Remarks on the early history of chondrichthyans, thelodonts, and some "higher elasmobranchs", in CoOPER R. (ed.), Hornibrook Symposium (Christchurch, 1985). New Zealand Geological Survey Record 9: 93-95.

TURNER S. 1994a. - Thelodont squamation. Ichthyolith Issues 13: 12-15.

TURNER S. 1994b. - Thermal alteration of microscopic fish remains. Ichthyolith Issues 13: 25-26.

Turner S. \& BlieCK A. 1995. — Conodont-vertebrate comparison and significance of micro-ornament, in Brock G. A. (ed.), The AUSCOS-1/BOUCOT Symposium (Macquarie University, Sydney, July 18-21, 1995). Abstracts: 105.

Turner S., Blieck A. \& Nowlan G. S. 2004. - Vertebrates (Agnathans and Gnathostomes), in WeBby B. D., Paris F., Droser M. L. \& Percival I. G. (eds), The Great Ordovician Biodiversity Event. Columbia University Press, New York: 327-335 + 395-466.

Vandenbroucke T. R. A., Gabbott S. E., Paris F., Aldridge R. J. \& Theron J. N. 2009. - Chitinozoans and the age of the Soom Shale, an Ordovician black shale Lagerstätte, South Africa. Journal of Micropalaeontology 28: 53-66.

Vannier J., Steiner M., Renvoise E., Hu S.-X. \& Casanova J.-P. 2007. - Early Cambrian origin of modern food webs: evidence from predator arrow worms. Proceedings of the Royal Society B 274: 627-633.

Walliser O. H. 1994. - Architecture of the polygnathid conodont apparatus, in KÖNIGSHOF P. \& Werner R. (eds), Willi Ziegler-Festschrift I. Courier Forschungsinstitut Senckenberg 168: 31-36.

WARSHAWSKY H. 1989. - Organization of crystals in enamel. The Anatomical Record 224: 242-262.

WatABE N. 1990. - Calcium phosphate structures in invertebrates and protozoans, in CARTER J. G. (ed.), Skeletal Biomineralization: Patterns, Processes and Evolutionary Trends. Volume I, Chapter 4. Van Nostrand Reinhold, New York: 35-44.

WeDDIGE K. 1989. - Conodonten - problematische Fossilien. Natur und Museum 119 (3): 67-82.

WedDige K. 1990. — Pathological conodonts. Courier Forschungsinstitut Senckenberg 118: 563-589.

Wilson M. V. H., Hanke G. F. \& MÄrss T. 2007. Paired fins of jawless vertebrates and their homologies across the "agnathan"-gnathostome transition, in ANDERSON J. S. \& Sues H.-D. (eds), Major Transitions in Vertebrate Evolution. Indiana University Press, Bloomington and Indianapolis: 122-149.

WRIGHT J. 1990. — Conodont geochemistry: a key to the Palaeozoic. Courier Forschungsinstitut Senckenberg 118: 227-305.

YounG G. C. 1997. - Ordovician microvertebrate remains from the Amadeus Basin, central Australia. Journal of Vertebrate Paleontology 17: 1-25.

YounG G. C. 2009. - An Ordovician vertebrate from western New South Wales, with comments on Cam- 
bro-Ordovician vertebrate distribution patterns. Alcheringa 33: 79-89.

Zhang S., Aldridge R. J. \& Donoghue P. C. J. 1997. - An Early Triassic conodont with periodic growth? Journal of Micropalaeontology 16: 65-72.

Zhang X.-L., ShU D.-G., Li Y. \& Han J. 2001. — New sites of Chengjiang fossils: crucial windows on the
Cambrian explosion. Journal of the Geological Society of London 158: 211-218.

Zylberberg L., Sire J.-Y. \& NANCI A. 1997. — Immunodetection of amelogenin-like proteins in the ganoine of experimentally regenerating scales of $\mathrm{Ca}$ lamoichthys calabaricus, a primitive actinopterygian fish. The Anatomical Record 249: 86-95.

Submitted on 4 August 2008; accepted on 26 February 2010. 


\section{APPENDIX 1}

List of characters used in the data matrix. The first number (in bold) applies to our matrix; the second number (in italics and parentheses) corresponds to that used in the Donoghue et al.'s (2000: table 1) matrix. Characters 20 and 31 have been changed as noted in the text.

1 (1) neural crest: 0. absent; 1. present

2 (2) brain: 0 . absent; 1 . present

3 (3) olfactory peduncles: 0 . absent; 1 . present

4 (4) pineal organ: 0 . absent; 1 . present and covered; 2. present and uncovered

5 (5) divided pituitary: 0. absent; 1. present

6 (7) optic tectum: 0. absent; 1. present

7 (8) cerebellum: 0 . absent; 1 . present

8 (14) number of nasal openings: 0 . none; 1 . paired; 2 . single median

$10(16)$

11 (17) position of nasohypophyseal opening: 0. none; 1 . terminal; 2. dorsal

12 (18) olfactory organ: 0. absent; 1 . paired; 2. unpaired

13 (19) extrinsic eye musculature: 0 . absent; 1 . present

14 (20) semicircular canals in labyrinth: 0. absent; 1. 1; 2. 2; 3. 3

15 (21) vertical semicircular canal looped: 0. absent; 1. present

16 (22) endolymphatic ducts open externally: 0. absent; 1. present

17 (23) sensory line system with neuromasts: 0. absent; 1. present

18 (25) sensory line grooves or canals: 0. absent; 1. present on head only; 2 . on head plus body

19 (26) sensory line: 0 . absent; 1 . in grooves; 2 . in canals

20 (27) gill opening shape: 0 . present, simple slits; 1 . present, pouch-shaped; 2 . present, slits to chambers

21 (28) gill relative position: 0. alternate; 1 . symmetrical

22 (29) branchial series: 0 . more than $10 ; 1$. fewer than 10

23 (30) gill openings lateral, slanting row: 0. absent; 1. present

24 (31) gills opening: 0. laterally; 1 . ventrally

25 (32) opercular flaps: 0. absent; 1. present

26 (34) gill lamellae with filaments: 0. absent; 1. present

27 (35) mouth position: 0. terminal; 1 . ventral

28 (37) relative position of atrium and ventricle: 0 . well separated; 1 . close

29 (38) closed pericardium: 0. absent; 1. present

30 (40) paired dorsal aortae: 0 . absent; 1 . present

31 (41) lateral head vein: 0. absent; 1. present
32 (43)

33 (44)

34 (45)

$35(46)$

$36(47)$

37 (48)

38 (49)

39 (50)

40 (51)

$41(52)$

42 (54)

43 (55)

44 (58)

45 (59)

$46(60)$

47 (61)

48 (62)

49 (63)

50 (64)

51 (65)

$52(66)$

53 (67)

$54(68)$

55 (69)

$56(70)$

$57(71)$

$58(72)$

59 (73)

$60(74)$

61 (75)

62 (76)

63 (77) subaponeurotic vascular plexus: 0. absent; 1. present separate dorsal fin: 0 . absent; 1 . present anal fin separate: 0 . absent; 1 . present unpaired fin ray supports closeset: 0 . absent; 1. present paired lateral fin folds: 0 . absent; 1 . present constricted pectorals: 0 . absent; 1 . present tail shape: 0 . isocercal; 1 . hypocercal; 2 . epicercal preanal median fold: 0 . absent; 1 . present ability to synthesise creatine phosphatase: 0 . absent; 1. present visceral arches fused to neurocranium: 0. absent; 1. present trematic rings: 0 . absent; 1 . present arcualia: 0 . absent; 1 . present braincase with lateral walls: 0 . absent; 1 . present neurocranium entirely closed dorsally, covering brain: 0 . absent; 1. present occiput enclosing vagus and glossopharyngeal: 0 . absent; 1. present

annular cartilage: 0 . absent; 1 . present trunk dermal skeleton: 0 . absent; 1 . present perichondral bone: 0 . absent; 1 . present calcified cartilage: 0 . absent; 1 . present calcified dermal skeleton: 0 . absent; 1 . present spongy aspidin: 0 . absent; 1 . present lamellar aspidin: 0 . absent; 1 . present cellular bone: 0 . absent; 1 . present dentine: 0 . absent; 1 . present, mesodentine; 2 . present, orthodentine

enamel/oid: 0. absent; 1. present, monotypic enamel; 2. present, enameloid

three-layered exoskeleton: 0. absent; 1. present cancellar layer in exoskeleton with honeycomb-shaped cavities: 0 . absent; 1 . present

composition of scales/denticles: 0 . absent; 1. present, single odontode; 2 . present, polyodontode

scales: 0 . absent; 1 . present, diamond-shaped; 2. present, rod-shaped

oakleaf-shaped tubercles: 0 . absent; 1 . present oral plates: 0 . absent; 1 . present

denticles in pharynx: 0 . absent; 1 . present 


\section{APPENDIX 1 - Continuation.}

64 (78) dermal head covering in adult state: 0. absent; 1 . small micromeric; 2. large dermal plates or shield

65 (79) large unpaired ventral and dorsal dermal plates on head: 0. absent; 1 . present
66 (80) massive endoskeletal head shield covering gills dorsally: 0. absent; 1 . present

67 (81) sclerotic ossicles: 0. absent; 1. present

68 (82) ossified scleral capsule: 0 . absent; 1 . present

\section{APPENDIX 2}

Changes of coding from Donoghue et al. (2000); their character numbers are listed in italics after our new numbering as in Appendix 1.

TUNICATA

2 (2) Brain: 0 to ?: larval ascidians have an anterior enlargement of the dorsal nerve chord.

22 (29) Elongate branchial series: 0 to ?: the number of gill slits is very variable within tunicates $(1->10)$, and it is unclear if the sessile forms with many slits are close to the ancestral form.

39 (50) Preanal median fold: ? to 0: these folds could only occur in larval forms, but none are known.

\section{CepHalochordata}

4 (4) Pinealorgan: ? to 0: we do not recognize homology between their "frontal eye" and the pineal organ in vertebrates.

36 (47) Paired lateral fin folds: 0 to 1: if "This refers to any lateral or ventrolateral fin-like fold" (Donoghue et al. 2000: 212), then the "metapleural" folds in Branchiostoma are included.

\section{MYXINOIDEA}

4 (4) Pineal organ: ? to 0: the pineal organ is absent, as noted by Donoghue et al. (2000).

12 (18) Olfactory organ: 2 to 1: only the nasopharyngeal opening is unpaired, the olfactory organ is paired.

23 (30) Slanting gill openings lateral: 0 to $0 / 1$ : different in different species and genera; one could even argue that they are partly ventral, promoting a recoding for character 24 (31).

25 (32) Opercular flaps: 0 to 0/1: Myxine garmani has one common opening with slits covered by flap, in Paramyxine atami slits are crowded with flaps.

31 (41) Large lateral head vein: 0 to 1 : lateral head vein = anterior part of anterior cardinal or anterior vena cava is present.

33 (44) Dorsal fin: 0 to 0/1: the anterior fin rays are free in contrast to rays of the caudal fin (Retzius 1892 refers to a dorsal fin).
38 (49) Tail shape: 0 to 1: Retzius (1892: pl. 3, fig. 10) shows a hypocercal structure (also Marinelli \& Strenger 1956: figs 108, 109).

42 (54) Trematic rings: 1 to 0

51 (65) Calcified dermal skeleton: ? to 0: there is no skeleton and no record that they are able to synthesise creatine phosphatase.

\section{PETROMYZONTIDA}

7 (8) Cerebellum: 0 to 1: a small cerebellum lies below the posterior choroid plexus in the anterior part of the medulla oblongata.

9 (15) Nasopharyngeal duct: 0 to 1: nasohypophyseal tract is present.

31 (41) Large lateral head vein: 0 to 1 : lateral head vein = anterior part of anterior cardinal or anterior vena cava present.

\section{Heterostraci}

4 (4) Pineal organ: 2 to 1: pineal is covered, at least for the primitive forms. It is always covered by a "pineal macula" which is a zone of the dorsal carapace (dorsal shield) with a peculiar structure (thinner bone). Blieck \& Goujet (1983) have described a pteraspid, called at that time Zascinaspis laticephala (now Gigantaspis laticephala after Pernègre \& Goujet 2007), with a hole in place of the pineal macula, that they thought to be natural. This is exceptional and might be in fact an artefact, that is, a broken zone because of thinness of the bone at that place. So, must be coded 1 .

6 (7) Optic tectum: ? to 1: they had eyes, therefore an optic tectum should have been present; this assumption is less of a leap of faith than, say, Donoghue et al. (2000) inferring that having a pore-like gill opening indicates pouch-shaped gills. 


\section{APPENDIX 2 - Continuation.}

9-10 (15-16)

Nasopharyngeal duct \& single nasohypophyseal opening respectively : must be coded 0 as there is no single nasohypophysial duct.

11 (17) Position of nasohypophyseal opening is not applicable, so remains?.

32 (43) Subaponeurotic vascular plexus: 1 to ?: one should not use one single form (Torpedaspis), if all others do not show the structure.

35 (46) Closely set unpaired fin ray supports: 1 to ?: this character is non applicable. There is one unpaired fin, the caudal fin, but apparently no fin ray support.

47 (61) Annular cartilage: ? to 0: the structure of the mouth parts does not permit an annular cartilage.

60 (74) Scale shape: 1 to $1 / 2$ : both rod- and diamond-shaped scales occur, the former might be the primitive condition. In fact the patterns of scales are more diverse. They are "rod-shaped" in Ordovician taxa such as the arandaspids, which are not heterostracans, but basal pteraspidomorphs. They are rhombic (diamond-shaped) in Eriptychius (Ordovician, N America), and the APP group of Blieck et al. (1991), that is, anchipteraspidsprotopteraspids-pteraspids in which are also included the psammosteids. They are more rectangular and thin on the flank of the cyathaspids (Blieck et al.'s 1991 CA group for cyathaspids-amphiaspids). However, rhombic-like scales also occur in this group: the smaller, lateral, lower scales of the trunk of cyathaspids, and a few isolated scales attributed to amphiaspids.

\section{ASTRASPIS}

6 (7) Optic tectum: ? to 1: optic tectum should have been present (there are eyes).

21 (28) Gills: ? to 1: we would argue that the gill position is symmetrical.

33 (44) Dorsal fin: ? to 0: no separate dorsal fin.

34 (45) Anal fin separate: ? to 0: no separate ventral fin.

\section{ERIPTYCHIUS}

6 (7) Optic tectum: ? to 1: optic tectum should have been present (there are eyes).

32 (43) Subaponeurotic vascular plexus: 1 to ?: We do not accept the homology between vascular canals in Eriptychius and the vascular plexus.
48 (62) Trunk dermal skeleton: ? to 1: trunk dermal skeleton must be present, if character 60 (74) is coded 1.

56 (70) Enamellenameloid: 1 to 2: the prismatic tissue is different to enamel in polarized light (Denison 1967).

\section{ARANDASPIDA}

6 (7) Optic tectum: ? to 1: optic tectum should have been present (there are eyes).

17 (23) Sensory line system with neuromasts: ? to 1: we would argue that the lateral line system - even as grooves - has neuromasts.

36 (47) Paired lateral fin folds: ? to 0: no paired lateral fin folds.

38 (49) Tail shape: ? to 1: isocercal tail with median extension.

47 (61) Annular cartilage: ? to 0: the structure of the mouth parts does not permit an annular cartilage.

52 (66) Spongy aspidin: ? to 1: aspidin present.

53 (67) Lamellar aspidin: ? to 1: aspidin present.

54 (68) Cellular bone: ? to 0: Sansom et al. (2005) showed that arandaspids have a cellular bone.

ANASPIDA

6 (7) Optic tectum: ? to 1: optic tectum should have been present (there are eyes).

9 (15) Nasopharyngeal duct: ? to 1: nasohypophysial opening is present.

17 (23) Sensory line with neuromasts: ? to 1: we would argue, if one accepts a lateral line system - even as grooves - it has neuromasts.

21 (28) Gills: ? to 1: we would argue that the gill position is symmetrical.

32 (43) Subaponeurotic vascular plexus: ? to 0: histology of scales points to subcutaneous vascularisation.

\section{JAMOYTIUS}

6 (7) Optic tectum: ? to 1: optic tectum should have been present (there are eyes).

9 (15) Nasopharyngeal duct: ? to 1: if 11(17) (one nasohypophyseal opening) is coded as 1 , then this character (nasohypophyseal duct) is also 1 .

21 (28) Gill relative position: ? to 1: We would argue that the gill position is symmetrical.

47 (61) Annular cartilage: 1 to 0 (Janvier \& Arsenault 2007). 


\section{APPENDIX 2 - Continuation.}

\section{EUPHANEROPS}

Recoding follows Janvier \& Arsenault (2007); nevertheless here we interpret "lateral head stains" as eyes.

6 (7) Optic tectum: ? to 1: optic tectum should have been present (there are eyes).

21 (28) Gill relative position: ? to 1: symmetrical.

25 (32) Opercular flaps: ? to 0.

26 (34) Gill lamellae with filaments: ? to 1.

29 (38) Closed pericardium: ? to 1.

33 (44) Dorsal fin: ? to 0.

36 (47) Paired lateral fin folds: ? to 1.

37 (48) Constricted pectorals: ? to 0.

39 (50) Preanal median fold: ? to 0.

42 (54) Trematic rings: 1 to 0.

43 (55) Arcualia: ? to 1.

44 (58) Braincase with lateral walls: ? to 0.

48 (62) Trunk dermal skeleton: 1 to 0.

49 (63) Perichondral bone: ? to 0.

50 (64) Calcified cartilage: ? to 0.

51 (65) Calcified dermal skeleton: 1 to 0.

52-59 (66-73) ? to 0 .

60 (74) Scales: 2 to 0.

66 (80) Massive endoskeletal head shield over gills: 0 to 1: "massive" endoskeleton covering gills dorsally.

67 (81) Sclerotic ossicles: ? to 0.

\section{Osteostraci}

9 (15) Nasopharyngeal duct: 0 to 1: we would argue that there is a (very short) nasohypophysial duct.

12 (18) Olfactory organ: 1 to 2: olfactory organ is unpaired.

GALEASPIDA

8 (14) Number of nasal openings: 2 to 1.

9 (15) Nasopharyngeal duct: 1 to 0 : both nasal sacs lie on opposite sides of the median opening, and the unpaired hypophysial duct is in between.

33 (44) Dorsal fin: ? to 0: dorsal fin absent.

34 (45) Anal fin separate: 1 to 0 : anal fin absent.

35 (46) Closely set unpaired fin ray supports: 1 to ?: not applicable.

THELODONTI

Loganellia scotica

19 (26) Sensory line: 2 to 2/1: grooves could be possible too.

25 (32) Opercular flaps: 1 to 0: no opercular flaps known.
32 (43) Subaponeurotic vascular plexus: ? to 0: no indication of vascular plexus.

\section{PITURIASPIDA}

Although there is no proof of bone or other calcified/phosphatic tissue, we accept consensus interpretation as a vertebrate rather than an arthropod.

65 (79) Large head plates: 0 to 1 : if it is interpreted as a vertebrate, there are large plates.

JAWED VERTEBRATES

4 (4) Pineal organ: 1 to $1 / 2$ : we do not know what is primitive (covered or uncovered pineal organ) in gnathostomes.

19 (26) Sensory line: 2 to $2 / 1$ : we do not know what is primitive (in grooves or canals) in gnathostomes.

20 (27) Gill openings: 0 to 2 : following new character codings.

32 (43) Subaponeurotic vascular plexus: 0 to 0/1: this type of system is present in the snout of sharks and primitive osteichthyans.

36 (47) Paired lateral fin folds: 0 to 0/1: possible stem gnathostomes from Northwest Territories, Canada (Wilson et al. 2007) as well as Lochkovian acanthothoracids from southeastern Australia (CJB pers. obs.) had ventrolateral rows of spines or spinelets.

55 (69) Dentine: 2 to 1: mesodentine is found in the oldest putative gnathostome (Ordovician Skiichthys Smith \& Sansom 1997) and placoderms, regarded as the least derived gnathostome group.

\section{CONODONTA}

1 (1) Neural crest: 1 to ?: the presence of dentine and extrinsic eye musculature on which the authors' scoring for neural crest was based, are questioned.

2 (2) Brain: 1 to ?: presence of paired sensory organs and brain structure in conodonts is questionable.

13 (19) Extrinsic eye musculature: 1 to ? (linked to character 1): we are unconvinced that the paired anterior structures are eyes, let alone that the muscles associated with them are eye muscles.

21 (28) Gill relative position: 1 to ?: presence of gills is questionable, hence position in unknown or inapplicable.

35 (46) Unpaired fin-ray supports closeset: 1 to ?: we do not consider the fin-ray supports homologous with those of vertebrates. 


\section{APPENDIX 2 - Continuation.}

41 (52) Visceral arches fused to neurocranium: ? to 0: no visceral arches present.

42 (54) Trematic ring: ? to 0: no gills, so no trematic rings.

43 (55) Arcualia: ? to 0: arcualia never recorded.

51 (65) Calcified dermal skeleton: 1 to 0: many invertebrates have a calcified dermal skeleton, which is not homologous with that of vertebrates. Conodont elements are similarly not homologous with the dermal skeleton of any other group.

55 (69) Dentine: ? to 0: we do not accept that dentine is found in conodont elements.

56 (70) Enamellenameloid: 1 to 0: there is no tissue with the optical properties of enamel.
59 (73) Composition of the scales/denticles/teeth made up by several odontodes: 2 to 0 : conodont elements are "regarded as an independent experimentation, as a convergence to the dermal skeleton of vertebrates" by Reif (2002: 64), and cannot thus be homologous to odontodes.

63 (77) Denticles in the pharynx: 1 to 0: if one accepts Donoghue et al.'s (2000: 238) statement that "Whether conodont elements are homologous to true teeth is a moot point", by their criteria, phosphatic tooth-like elements such as scolecodonts and phyllocarids would also "count" as teeth/denticles. Conodont elements are not homologous to thelodont and shark pharyngeal denticles (e.g., Turner 1985, 1994a; Reif 2006; Märss et al. 2007). 


\section{APPENDIX 3}

Apomorphy lists for character changes at nodes in examples of trees showing the same topology, generated by ACCTRAN (tree \#6 of 27) and DELTRAN (tree \#4 of 27) PAUP 4.0 b10 analyses (see Fig. 5A, B). Character numbers (Char.) correspond to those described in Appendix 1; the black arrow " $\triangleright$ " under the change column represents unambiguous changes and the white arrow " $\triangleright$ " represents ambiguous changes; all changes are one step. Abbreviation: $\mathbf{C l}$, consistency index. Note: 1, number in italics and parentheses corresponds to that used in the Donoghue et al.'s (2000; table 1) matrix.

\begin{tabular}{|c|c|c|c|c|c|c|c|}
\hline \multicolumn{4}{|c|}{ ACCTRAN tree \#6 } & \multicolumn{4}{|c|}{ DELTRAN tree \#4 } \\
\hline Branch & Char. \# 1 & Cl & Change & Branch & Char. \# 1 & Cl & Change \\
\hline \multirow{4}{*}{$\begin{array}{l}\text { node_34 } \\
\triangleright \text { Cephalochordata }\end{array}$} & $30(40)$ & 0.333 & $0 \triangleright 1$ & node_34 & $30(40)$ & 0.333 & $0 \triangleright 1$ \\
\hline & & & & $\triangleright$ Cephalochordata & & & \\
\hline & $36(47)$ & 0.25 & 0.1 & & $36(47)$ & 0.25 & 0.1 \\
\hline & $39(50)$ & 0.333 & 0.1 & & $39(50)$ & 0.333 & $0 \cdot 1$ \\
\hline \multirow{17}{*}{ node_34 $\triangleright$ node_33 } & $1(1)$ & 1 & $0 \triangleright 1$ & node_34 $\triangleright$ node_33 & 38 (49) & 0.667 & 0.1 \\
\hline & $2(2)$ & 1 & $0 \triangleright 1$ & & $40(51)$ & 1 & $0 \cdot 1$ \\
\hline & $5(5)$ & 1 & $0 \triangleright 1$ & node_33 $\triangleright$ node_32 & $1(1)$ & 1 & $0 \triangleright 1$ \\
\hline & $6(7)$ & 1 & $0 \triangleright 1$ & (Craniata) & $2(2)$ & 1 & $0 \triangleright 1$ \\
\hline & $8(14)$ & 0.667 & $0 \triangleright 2$ & & $5(5)$ & 1 & $0 \triangleright 1$ \\
\hline & $9(15)$ & 0.333 & $0 \triangleright 1$ & & $6(7)$ & 1 & $0 \triangleright 1$ \\
\hline & $10(16)$ & 0.333 & $0 \triangleright 1$ & & $8(14)$ & 0.667 & $0 \triangleright 2$ \\
\hline & $11(17)$ & 0.5 & $0 \triangleright 1$ & & $9(15)$ & 0.333 & $0 \triangleright 1$ \\
\hline & 12 (18) & 1 & $0 \triangleright 1$ & & $10(16)$ & 0.333 & $0 \triangleright 1$ \\
\hline & $14(20)$ & 1 & $0 \triangleright 1$ & & $12(18)$ & 1 & $0 \triangleright 1$ \\
\hline & $18(25)$ & 0.667 & $0 \triangleright 1$ & & $19(26)$ & 0.667 & $0 \triangleright 1$ \\
\hline & $19(26)$ & 0.667 & $0 \triangleright 1$ & & $20(27)$ & 1 & $0 \triangleright 1$ \\
\hline & $20(27)$ & 1 & $0 \triangleright 1$ & & $31(41)$ & 1 & $0 \triangleright 1$ \\
\hline & $23(30)$ & 0.333 & $0 \triangleright 1$ & & $41(52)$ & 0.5 & 0.1 \\
\hline & $31(41)$ & 1 & $0 \triangleright 1$ & node_32 $\triangleright$ Myxinoidea & $11(17)$ & 0.5 & $0 \triangleright 1$ \\
\hline & $38(49)$ & 0.667 & 0.1 & & $14(20)$ & 1 & $0 \triangleright 1$ \\
\hline & $40(51)$ & 1 & 0.1 & & $18(25)$ & 0.667 & $0 \triangleright 1$ \\
\hline node_33 $\triangleright$ node_32 & $41(52)$ & 0.5 & 0.1 & & $30(40)$ & 0.333 & $0 \triangleright 1$ \\
\hline \multirow{3}{*}{ node_32 $\triangleright$ Myxinoidea } & $30(40)$ & 0.333 & $0 \triangleright 1$ & & 32 (43) & 0.5 & $0 \cdot 1$ \\
\hline & 32 (43) & 0.5 & 0.1 & & $39(50)$ & 0.333 & $0 \cdot 1$ \\
\hline & 39 (50) & 0.333 & 0.1 & $\begin{array}{l}\text { node_32 } \\
\quad \text { node_31 }\end{array}$ & $4(4)$ & 1 & 0.2 \\
\hline \multirow[t]{14}{*}{ node_32 $\triangleright$ node_31 } & $4(4)$ & 1 & $0 \cdot 2$ & (Vertebrata) & 7 (8) & 1 & 0.1 \\
\hline & 7 (8) & 1 & 0.1 & & 11 (17) & 0.5 & $0 \triangleright 2$ \\
\hline & 11 (17) & 0.5 & $1 \triangleright 2$ & & 13 (19) & 1 & $0 \cdot 1$ \\
\hline & 13 (19) & 1 & 0.1 & & 14 (20) & 1 & $0 \triangleright 2$ \\
\hline & $14(20)$ & 1 & $1 \triangleright 2$ & & 17 (23) & 1 & $0 \cdot 1$ \\
\hline & 17 (23) & 1 & 0.1 & & $18(25)$ & 0.667 & $0 \triangleright 2$ \\
\hline & $18(25)$ & 0.667 & $1 \triangleright 2$ & & 21 (28) & 1 & $0 \cdot 1$ \\
\hline & 21 (28) & 1 & 0.1 & & $23(30)$ & 0.333 & $0 \triangleright 1$ \\
\hline & 26 (34) & 1 & 0.1 & & 26 (34) & 1 & $0 \cdot 1$ \\
\hline & 28 (37) & 1 & 0.1 & & 28 (37) & 1 & $0 \cdot 1$ \\
\hline & 29 (38) & 1 & 0.1 & & 29 (38) & 1 & 0.1 \\
\hline & 34 (45) & 0.333 & $0 \triangleright 1$ & & 43 (55) & 1 & 0.1 \\
\hline & 43 (55) & 1 & 0.1 & node_31 $\triangleright$ node_20 & $34(45)$ & 0.333 & $0 \triangleright 1$ \\
\hline & 44 (58) & 0.5 & $0 \triangleright 1$ & & 47 (61) & 1 & $0 \cdot 1$ \\
\hline \multirow[t]{2}{*}{ node_31 $\triangleright$ node_20 } & 47 (61) & 1 & 0.1 & & $50(64)$ & 0.333 & $0 \cdot 1$ \\
\hline & $50(64)$ & 0.333 & 0.1 & node_20 & 22 (29) & 0.333 & 0.1 \\
\hline \multirow{3}{*}{$\begin{array}{l}\text { node_20 } \\
\quad \text { Petromyzontida }\end{array}$} & 22 (29) & 0.333 & $0-1$ & a & $33(44)$ & 0333 & $0=1$ \\
\hline & & & & & & & \\
\hline & $42(54)$ & 0.5 & 0.1 & & $44(58)$ & $\begin{array}{l}0.5 \\
0.5\end{array}$ & $0 \triangleright 1$ \\
\hline node_20 & $35(46)$ & 0.333 & 0.1 & node_20 & $35(46)$ & 0.333 & 0.1 \\
\hline • Euphanerops & & & & $\triangleright$ Euphanerops & & & \\
\hline
\end{tabular}


APPENDIX 3 - Continuation.

\begin{tabular}{|c|c|c|c|c|c|c|c|}
\hline \multicolumn{4}{|c|}{ ACCTRAN tree \#6 } & \multicolumn{4}{|c|}{ DELTRAN tree \#4 } \\
\hline Branch & Char. \# 1 & $\mathrm{Cl}$ & Change & Branch & Char. \# 1 & $\mathrm{Cl}$ & Change \\
\hline & $36(47)$ & 0.25 & $0 \cdot 1$ & & $36(47)$ & 0.25 & $0 \cdot 1$ \\
\hline & 44 (58) & 0.5 & $1 \triangleright 0$ & & $66(80)$ & 0.333 & 0.1 \\
\hline \multirow{10}{*}{ node_31 $\triangleright$ node_30 } & $66(80)$ & 0.333 & 0.1 & node_31 $\triangleright$ node_30 & $48(62)$ & 1 & 0.1 \\
\hline & $3(3)$ & 0.5 & $0 \triangleright 1$ & (Euvertebrata) & $51(65)$ & 1 & $0 \cdot 1$ \\
\hline & $15(21)$ & 1 & $0 \triangleright 1$ & & 60 (74) & 0.667 & 0.2 \\
\hline & $45(59)$ & 1 & $0 \triangleright 1$ & node_30 $\triangleright$ node_29 & $53(67)$ & 0.5 & $0 \triangleright 1$ \\
\hline & $46(60)$ & 1 & $0 \triangleright 1$ & & 59 (73) & 0.667 & $0 \triangleright 2$ \\
\hline & 48 (62) & 1 & $0 \cdot 1$ & & 64 (78) & 0.5 & 0.1 \\
\hline & $51(65)$ & 1 & 0.1 & node_29 $\triangleright$ node_28 & $22(29)$ & 0.333 & 0.1 \\
\hline & $53(67)$ & 0.5 & $0 \triangleright 1$ & & 60 (74) & 0.667 & $2 \cdot 1$ \\
\hline & 59 (73) & 0.667 & $0 \triangleright 2$ & node_28 $\triangleright$ node_27 & 3 (3) & 0.5 & $1 \triangleright 0$ \\
\hline & 60 (74) & 0.667 & 0.2 & & $8(14)$ & 0.667 & $2 \triangleright 1$ \\
\hline \multirow[t]{3}{*}{ node_30 $\triangleright$ node_29 } & $36(47)$ & 0.25 & $0 \triangleright 1$ & & $9(15)$ & 0.333 & $1 \triangleright 0$ \\
\hline & $62(76)$ & 0.333 & $0 \triangleright 1$ & & $15(21)$ & 1 & $0 \triangleright 1$ \\
\hline & 64 (78) & 0.5 & 0.1 & & 32 (43) & 0.5 & $0 \triangleright 1$ \\
\hline \multirow{6}{*}{ node_29 $\triangleright$ node_28 } & $8(14)$ & 0.667 & $2 \triangleright 1$ & & 62 (76) & 0.333 & $0 \triangleright 1$ \\
\hline & $9(15)$ & 0.333 & $1 \triangleright 0$ & & 64 (78) & 0.5 & $1 \cdot 2$ \\
\hline & 22 (29) & 0.333 & 0.1 & node_27 $\triangleright$ node_23 & $52(66)$ & 1 & 0.1 \\
\hline & 32 (43) & 0.5 & $0 \triangleright 1$ & & 57 (71) & 0.5 & $0 \triangleright 1$ \\
\hline & 60 (74) & 0.667 & $2 \cdot 1$ & & $61(75)$ & 0.333 & 0.1 \\
\hline & $67(81)$ & 0.5 & $0 \triangleright 1$ & node_23 $\triangleright$ node_22 & $4(4)$ & 1 & $2 \cdot 1$ \\
\hline \multirow{3}{*}{ node_28 $\triangleright$ node_27 } & $36(47)$ & 0.25 & $1 \triangleright 0$ & & $55(69)$ & 0.667 & 0.2 \\
\hline & 57 (71) & 0.5 & $0 \triangleright 1$ & node_22 $\triangleright$ Heterostraci & $10(16)$ & 0.333 & 1.0 \\
\hline & 64 (78) & 0.5 & 1.2 & & $19(26)$ & 0.667 & $1 \cdot 2$ \\
\hline \multirow{5}{*}{ node_27 $\triangleright$ node_23 } & $10(16)$ & 0.333 & $1 \triangleright 0$ & & $23(30)$ & 0.333 & $1 \cdot 0$ \\
\hline & $52(66)$ & 1 & $0 \cdot 1$ & & 34 (45) & 0.333 & $0 \triangleright 1$ \\
\hline & 58 (72) & 0.5 & $0 \triangleright 1$ & & $38(49)$ & 0.667 & $1 \triangleright 0$ \\
\hline & $61(75)$ & 0.333 & 0.1 & & $39(50)$ & 0.333 & $0 \triangleright 1$ \\
\hline & 65 (79) & 0.333 & $0 \triangleright 1$ & & 58 (72) & 0.5 & $0 \triangleright 1$ \\
\hline \multirow[t]{5}{*}{ node_23 $\triangleright$ node_22 } & $4(4)$ & 1 & $2 \cdot 1$ & & 65 (79) & 0.333 & $0 \triangleright 1$ \\
\hline & $38(49)$ & 0.667 & $1 \triangleright 0$ & node_22 $\triangleright$ node_21 & $56(70)$ & 1 & 0.2 \\
\hline & $39(50)$ & 0.333 & $0 \triangleright 1$ & & 64 (78) & 0.5 & $2 \cdot 1$ \\
\hline & $55(69)$ & 0.667 & 0.2 & node_21 $\triangleright$ Astraspis & $18(25)$ & 0.667 & $2 \triangleright 1$ \\
\hline & 67 (81) & 0.5 & $1 \triangleright 0$ & node_21 21 Eriptychius & 50 (64) & 0.333 & 0.1 \\
\hline \multirow{2}{*}{ node_22 $\triangleright$ Heterostraci } & $19(26)$ & 0.667 & $1 \cdot 2$ & & $61(75)$ & 0.333 & $1 \cdot 0$ \\
\hline & $23(30)$ & 0.333 & 1.0 & $\begin{array}{l}\text { node_23 } \\
\triangleright \text { Arandaspida }\end{array}$ & $22(29)$ & 0.333 & $1 \cdot 0$ \\
\hline \multirow[t]{6}{*}{ node_22 $\triangleright$ node_21 } & $18(25)$ & 0.667 & $2 \triangleright 1$ & & $58(72)$ & 0.5 & $0 \triangleright 1$ \\
\hline & $34(45)$ & 0.333 & $1 \triangleright 0$ & & 60 (74) & 0.667 & $1 \cdot 2$ \\
\hline & $56(70)$ & 1 & $0 \cdot 2$ & & 65 (79) & 0.333 & $0 \triangleright 1$ \\
\hline & $58(72)$ & 0.5 & $1 \triangleright 0$ & & $67(81)$ & 0.5 & $0 \triangleright 1$ \\
\hline & 64 (78) & 0.5 & $2 \cdot 1$ & & 68 (82) & 0.5 & 0.1 \\
\hline & $65(79)$ & 0.333 & $1 \triangleright 0$ & node_27 $\triangleright$ node_26 & $16(22)$ & 1 & 0.1 \\
\hline \multirow[t]{2}{*}{ node_21 $\triangleright$ Eriptychius } & 50 (64) & 0.333 & $0 \cdot 1$ & & 19 (26) & 0.667 & $1 \cdot 2$ \\
\hline & $61(75)$ & 0.333 & 1.0 & & $23(30)$ & 0.333 & $1 \cdot 0$ \\
\hline \multirow{3}{*}{ node_23 $\triangleright$ Arandaspida } & $22(29)$ & 0.333 & $1 \cdot 0$ & & 44 (58) & 0.5 & $0 \triangleright 1$ \\
\hline & 60 (74) & 0.667 & $1 \cdot 2$ & & 45 (59) & 1 & $0 \triangleright 1$ \\
\hline & $68(82)$ & 0.5 & $0 \cdot 1$ & & $46(60)$ & 1 & $0 \triangleright 1$ \\
\hline \multirow[t]{7}{*}{ node_27 $\triangleright$ node_26 } & $16(22)$ & 1 & $0 \cdot 1$ & & 49 (63) & 1 & 0.1 \\
\hline & $19(26)$ & 0.667 & $1 \cdot 2$ & & $50(64)$ & 0.333 & 0.1 \\
\hline & $23(30)$ & 0.333 & 1.0 & & $67(81)$ & 0.5 & $0 \triangleright 1$ \\
\hline & $24(31)$ & 0.5 & $0 \triangleright 1$ & node_26 $\triangleright$ node_25 & $25(32)$ & 1 & $0 \cdot 1$ \\
\hline & 27 (35) & 0.333 & $0 \triangleright 1$ & & $33(44)$ & 0.333 & $0 \cdot 1$ \\
\hline & $35(46)$ & 0.333 & $0 \triangleright 1$ & & 34 (45) & 0.333 & $0 \triangleright 1$ \\
\hline & $38(49)$ & 0.667 & $1 \triangleright 2$ & & 37 (48) & 1 & 0.1 \\
\hline
\end{tabular}


APPENDIX 3 - Continuation.

\begin{tabular}{|c|c|c|c|c|c|c|c|}
\hline \multicolumn{4}{|c|}{ ACCTRAN tree \#6 } & \multicolumn{4}{|c|}{ DELTRAN tree \#4 } \\
\hline Branch & Char. \# 1 & $\mathrm{Cl}$ & Change & Branch & Char. \# 1 & $\mathrm{Cl}$ & Change \\
\hline & 49 (63) & 1 & 0.1 & & $38(49)$ & 0.667 & $1 \triangleright 2$ \\
\hline & 50 (64) & 0.333 & 0.1 & & $53(67)$ & 0.5 & $1 \cdot 0$ \\
\hline & $66(80)$ & 0.333 & $0 \triangleright 1$ & & 54 (68) & 1 & 0.1 \\
\hline \multirow[t]{7}{*}{ node_26 $\triangleright$ node_25 } & 25 (32) & 1 & 0.1 & & $55(69)$ & 0.667 & 0.1 \\
\hline & 33 (44) & 0.333 & 0.1 & & $57(71)$ & 0.5 & $0 \triangleright 1$ \\
\hline & 37 (48) & 1 & 0.1 & & 68 (82) & 0.5 & 0.1 \\
\hline & $53(67)$ & 0.5 & $1 \cdot 0$ & node_25 $\triangleright$ node_24 & 27 (35) & 0.333 & $0 \triangleright 1$ \\
\hline & 54 (68) & 1 & 0.1 & & $35(46)$ & 0.333 & $0 \triangleright 1$ \\
\hline & $55(69)$ & 0.667 & 0.1 & & $66(80)$ & 0.333 & $0 \triangleright 1$ \\
\hline & 68 (82) & 0.5 & $0 \cdot 1$ & node_24 $\triangleright$ Osteostraci & $3(3)$ & 0.5 & $1 \triangleright 0$ \\
\hline \multirow[t]{4}{*}{ node_25 $\triangleright$ node_24 } & $3(3)$ & 0.5 & $1 \triangleright 0$ & & $8(14)$ & 0.667 & $1 \triangleright 2$ \\
\hline & $8(14)$ & 0.667 & $1 \triangleright 2$ & & $9(15)$ & 0.333 & $0 \triangleright 1$ \\
\hline & $9(15)$ & 0.333 & $0 \triangleright 1$ & & 12 (18) & 1 & $1 \triangleright 2$ \\
\hline & $12(18)$ & 1 & $1 \triangleright 2$ & & $24(31)$ & 0.5 & $0 \triangleright 1$ \\
\hline \multirow{15}{*}{$\begin{array}{l}\text { node_25 } \\
\triangleright \text { Jawed vertebrate }\end{array}$} & 65 (79) & 0.333 & 0.1 & node_24 $\triangleright$ Pituriaspida & 65 (79) & 0.333 & 0.1 \\
\hline & $10(16)$ & 0.333 & 1.0 & $\begin{array}{l}\text { node_25 } \\
\triangleright \text { Jawed vertebrates }\end{array}$ & $10(16)$ & 0.333 & 1.0 \\
\hline & $11(17)$ & 0.5 & $2 \cdot 0$ & (Gnathostomata) & $11(17)$ & 0.5 & $2 \cdot 0$ \\
\hline & $14(20)$ & 1 & $2 \cdot 3$ & & $14(20)$ & 1 & $2 \cdot 3$ \\
\hline & $20(27)$ & 1 & 1.2 & & $20(27)$ & 1 & $1 \cdot 2$ \\
\hline & $24(31)$ & 0.5 & $1 \triangleright 0$ & & $30(40)$ & 0.333 & $0 \triangleright \overline{1}$ \\
\hline & 27 (35) & 0.333 & $1 \triangleright 0$ & & $41(52)$ & 0.5 & 1.0 \\
\hline & $30(40)$ & 0.333 & $0 \triangleright 1$ & & 56 (70) & 1 & 0.1 \\
\hline & $41(52)$ & 0.5 & 1.0 & & $61(75)$ & 0.333 & 0.1 \\
\hline & $56(70)$ & 1 & 0.1 & & $62(76)$ & 0.333 & $1 \cdot 0$ \\
\hline & $61(75)$ & 0.333 & 0.1 & & $63(77)$ & 0.5 & 0.1 \\
\hline & 62 (76) & 0.333 & $1 \cdot 0$ & & 64 (78) & 0.5 & $2 \cdot 1$ \\
\hline & $63(77)$ & 0.5 & 0.1 & node_26 $\triangleright$ Galeaspida & $24(31)$ & 0.5 & $0 \triangleright 1$ \\
\hline & 64 (78) & 0.5 & $2 \cdot 1$ & & 27 (35) & 0.333 & $0 \triangleright 1$ \\
\hline & $66(80)$ & 0.333 & $1 \triangleright 0$ & & $59(17)$ & 0.667 & $2 \cdot 1$ \\
\hline \multirow{3}{*}{ node_26 $\triangleright$ Galeaspida } & 34 (45) & 0.333 & $1 \triangleright 0$ & & 66 (80) & 0.333 & $0 \triangleright 1$ \\
\hline & $57(71)$ & 0.5 & $1 \triangleright 0$ & $\begin{array}{l}\text { node_28 } \\
\triangleright \text { Loganellia scotica }\end{array}$ & $33(44)$ & 0.333 & 0.1 \\
\hline & 59 (73) & 0.667 & $2 \cdot 1$ & & $36(47)$ & 0.25 & $0 \triangleright 1$ \\
\hline \multirow{5}{*}{$\begin{array}{l}\text { node_28 } \\
\triangleright \text { Loganellia scotica }\end{array}$} & $33(76)$ & 0.333 & 0.1 & & $55(69)$ & 0.667 & 0.1 \\
\hline & $55(77)$ & 0.667 & 0.1 & & $59(17)$ & 0.667 & $2 \cdot 1$ \\
\hline & 59 (17) & 0.667 & $2 \cdot 1$ & & 63 (77) & 0.5 & 0.1 \\
\hline & $62(76)$ & 0.333 & $1 \triangleright 0$ & node_29 $\triangleright$ Anaspida & $36(47)$ & 0.25 & $0 \triangleright 1$ \\
\hline & 63 (77) & 0.5 & $0 \cdot 1$ & & $62(76)$ & 0.333 & $0 \triangleright 1$ \\
\hline \multirow{4}{*}{ node_30 $\triangleright$ Jamoytius } & $11(17)$ & 0.5 & $2 \triangleright 1$ & node_30 $\triangleright$ Jamoytius & $11(17)$ & 0.5 & $2 \triangleright 1$ \\
\hline & 27 (35) & 0.333 & 0.1 & & 27 (35) & 0.333 & 0.1 \\
\hline & 35 (46) & 0.333 & 0.1 & & 35 (46) & 0.333 & 0.1 \\
\hline & 42 (54) & 0.5 & 0.1 & & $42(54)$ & 0.5 & 0.1 \\
\hline
\end{tabular}




\section{APPENDIX 4}

Comparative character diagnostics - $\mathbf{C l}$ (consistency index), HI (homoplasy index), RI (retention index) values - for the 68 characters used in our analyses (Fig. 5A, B) and for the same 68 characters in tree 1 of three equal-length trees based on the codings in Donoghue et al. (2000), for the 17 base taxa (the strict consensus tree generated by their data for the 68 characters yields the same topology as their figure 7A tree).

\begin{tabular}{|c|c|c|c|c|c|c|c|}
\hline \multirow{2}{*}{$\begin{array}{l}\text { Char- } \\
\text { acter }\end{array}$} & \multirow{2}{*}{$\begin{array}{l}\text { Donoghue et al. character number, } \\
\text { with character description }\end{array}$} & \multicolumn{3}{|c|}{ Our analysis } & \multicolumn{3}{|c|}{ Donoghue et al. analysis } \\
\hline & & $\mathbf{C l}$ & HI & RI & $\mathbf{C l}$ & HI & $\mathbf{R} \mathbf{I}$ \\
\hline 1 & (1 neural crest) & 1 & 0 & 1 & 1 & 0 & 1 \\
\hline 2 & (2 brain) & 1 & 0 & $0 / 0$ & 1 & 0 & 1 \\
\hline 3 & ( 3 olfactory peduncles) & 0.5 & 0.5 & 0.5 & 0.5 & 0.5 & 0.5 \\
\hline 4 & (4 pineal organ) & 1 & 0 & 1 & 0.667 & 0.333 & 0 \\
\hline 5 & (5 divided pituitary) & 1 & 0 & 1 & 1 & 0 & 1 \\
\hline 6 & (7 optic tectum) & 1 & 0 & 1 & 1 & 0 & 1 \\
\hline 7 & (8 cerebellum) & 1 & 0 & 1 & 1 & 0 & 1 \\
\hline 8 & (14 number of nasal openings) & 0.667 & 0.333 & 0.667 & 0.667 & 0.333 & 0.5 \\
\hline 9 & (15 nasopharyngeal duct) & 0.333 & 0.667 & 0.5 & 0.5 & 0.5 & 0 \\
\hline 10 & (16 single nasohyophyseal opening) & 0.333 & 0.667 & 0.333 & 0.5 & 0.5 & 0.5 \\
\hline 11 & (17 position of nasohypophyseal opening) & 0.5 & 0.5 & 0.333 & 0.5 & 0.5 & 0.333 \\
\hline 12 & (18 olfactory organ) & 1 & 0 & 1 & 1 & 0 & 1 \\
\hline 13 & (19 extrinsic eye musculature) & 1 & 0 & 1 & 1 & 0 & 1 \\
\hline 14 & (20 semicircular canals in labyrinth) & 1 & 0 & 1 & 1 & 0 & 1 \\
\hline 15 & (21 vertical semicircular canal looped) & 1 & 0 & 1 & 1 & 0 & 1 \\
\hline 16 & (22 endolymphatic ducts open externally) & 1 & 0 & 1 & 1 & 0 & 1 \\
\hline 17 & (23 sensory line system with neuromasts) & 1 & 0 & 1 & 1 & 0 & 1 \\
\hline 18 & (25 sensory line grooves or canals) & 0.667 & 0.333 & 0.5 & 0.667 & 0.333 & 0.5 \\
\hline 19 & (26 sensory line) & 0.667 & 0.333 & 0.667 & 0.667 & 0.333 & 0.8 \\
\hline 20 & (27 gill openings) & 1 & 0 & 1 & 0.5 & 0.5 & 0.5 \\
\hline 21 & (28 gill relative position) & 1 & 0 & 1 & 1 & 0 & 1 \\
\hline 22 & (29 elongate branchial series) & 0.333 & 0.667 & 0.6 & 0.333 & 0.667 & 0.667 \\
\hline 23 & (30 gill openings lateral, slanting row) & 0.333 & 0.667 & 0.5 & 0.333 & 0.667 & 0.6 \\
\hline 24 & (31 position of gill openings) & 0.5 & 0.5 & 0 & 1 & 0 & 1 \\
\hline 25 & (32 opercular flaps) & 1 & 0 & 1 & 0.5 & 0.5 & 0.5 \\
\hline 26 & (34 gill lamellae with filaments) & 1 & 0 & 1 & 1 & 0 & 1 \\
\hline 27 & (35 mouth position) & 0.333 & 0.667 & 0.333 & 0.5 & 0.5 & 0.667 \\
\hline 28 & (37 relative position atrium \& ventricle) & 1 & 0 & 1 & 1 & 0 & 1 \\
\hline 29 & (38 closed pericardium) & 1 & 0 & 1 & 1 & 0 & 1 \\
\hline 30 & (40 paired dorsal aortae) & 0.333 & 0.667 & 0 & 0.333 & 0.667 & 0 \\
\hline 31 & (41 lateral head vein) & 1 & 0 & 1 & 1 & 0 & 1 \\
\hline 32 & (43 subaponeurotic vascular plexus) & 0.5 & 0.5 & 0.667 & 0.333 & 0.667 & 0.333 \\
\hline 33 & (44 separate dorsal fin) & 0.333 & 0.667 & 0.333 & 0.5 & 0.5 & 0.667 \\
\hline 34 & (45 anal fin separate) & 0.333 & 0.667 & 0.5 & 0.333 & 0.667 & 0.6 \\
\hline 35 & (46 unpaired fin-ray supports closely set) & 0.333 & 0.667 & 0.333 & 1 & 0 & 1 \\
\hline 36 & (47 paired lateral fin folds) & 0.25 & 0.75 & 0 & 0.5 & 0.5 & 0.5 \\
\hline 37 & (48 constricted pectorals) & 1 & 0 & 1 & 0.5 & 0.5 & 0.5 \\
\hline 38 & (49 tail shape) & 0.667 & 0.333 & 0.667 & 0.667 & 0.333 & 0.75 \\
\hline 39 & (50 preanal median fold) & 0.333 & 0.667 & 0 & 0.5 & 0.5 & 0.5 \\
\hline 40 & $\begin{array}{l}\text { ( } 51 \text { ability to synthesise creatine } \\
\text { phosphatase) }\end{array}$ & 1 & 0 & 1 & 1 & 0 & 1 \\
\hline 41 & (52 visceral arches fused to neurocranium) & 0.5 & 0.5 & 0.667 & 0.5 & 0.5 & 0.5 \\
\hline 42 & (54 trematic rings) & 0.5 & 0.5 & 0 & 0.5 & 0.5 & 0.5 \\
\hline 43 & (55 arcualia) & 1 & 0 & 1 & 1 & 0 & 1 \\
\hline 44 & (58 braincase with lateral walls) & 0.5 & 0.5 & 0.667 & 1 & 0 & 1 \\
\hline 45 & $\begin{array}{l}\text { (59 neurocranium entirely closed } \\
\text { dorsally, covering brain) }\end{array}$ & 1 & 0 & 1 & 1 & 0 & 1 \\
\hline 46 & $\begin{array}{l}\text { (60 occiput enclosing vagus } \\
\text { and glossopharyngeal) }\end{array}$ & 1 & 0 & 1 & 1 & 0 & 1 \\
\hline 47 & (61 annular cartilage) & 1 & 0 & 1 & 0.5 & 0.5 & 0.5 \\
\hline
\end{tabular}


APPENDIX 4 - Continuation.

\begin{tabular}{|c|c|c|c|c|c|c|c|}
\hline \multirow{2}{*}{$\begin{array}{l}\text { Char- } \\
\text { acter }\end{array}$} & \multirow{2}{*}{$\begin{array}{l}\text { Donoghue et al. character number, } \\
\text { with character description }\end{array}$} & \multicolumn{3}{|c|}{ Our analysis } & \multicolumn{3}{|c|}{ Donoghue et al. analysis } \\
\hline & & $\mathbf{C l}$ & HI & $\mathbf{R I}$ & $\mathbf{C l}$ & HI & $\mathbf{R I}$ \\
\hline 48 & (62 trunk dermal skeleton) & 1 & 0 & 1 & 1 & 0 & 1 \\
\hline 49 & (63 perichondral bone) & 1 & 0 & 1 & 1 & 0 & 1 \\
\hline 50 & (64 calcified cartilage) & 0.333 & 0.667 & 0.6 & 0.5 & 0.5 & 0.75 \\
\hline 51 & (65 calcified dermal skeleton) & 1 & 0 & 1 & 1 & 0 & 1 \\
\hline 52 & (66 spongy aspidin) & 1 & 0 & 1 & 0.5 & 0.5 & 0.5 \\
\hline 53 & (67 lamellar aspidin) & 0.5 & 0.5 & 0.8 & 0.333 & 0.667 & 0.6 \\
\hline 54 & (68 cellular bone) & 1 & 0 & 1 & 0.5 & 0.5 & 0 \\
\hline 55 & (69 dentine) & 0.667 & 0.333 & 0.75 & 0.4 & 0.6 & 0.25 \\
\hline 56 & (70 enamel/oid) & 1 & 0 & 1 & 0.667 & 0.333 & 0.5 \\
\hline 57 & (71 three-layered exoskeleton) & 0.5 & 0.5 & 0.8 & 0.333 & 0.667 & 0.6 \\
\hline 58 & $\begin{array}{l}\text { (72 cancellar layer in exoskeleton with } \\
\text { honeycomb-shaped cavities) }\end{array}$ & 0.5 & 0.5 & 0 & 1 & 0 & 1 \\
\hline 59 & (73 composition of scales/denticles) & 0.667 & 0.333 & 0.833 & 0.667 & 0.333 & 0.75 \\
\hline 60 & (74 scales) & 0.667 & 0.333 & 0.857 & 0.667 & 0.333 & 0.857 \\
\hline 61 & (75 oakleaf-shaped tubercles) & 0.333 & 0.667 & 0.333 & 0.5 & 0.5 & 0.667 \\
\hline 62 & (76 oral plates) & 0.333 & 0.667 & 0.5 & 0.333 & 0.667 & 0.5 \\
\hline 63 & (77 denticles in pharynx) & 0.5 & 0.5 & 0 & 0.333 & 0.667 & 0 \\
\hline 64 & (78 dermal head covering in adult state) & 0.5 & 0.5 & 0.75 & 0.5 & 0.5 & 0.75 \\
\hline 65 & $\begin{array}{l}\text { (79 large unpaired ventral and dorsal } \\
\text { dermal plates on head) }\end{array}$ & 0.333 & 0.667 & 0 & 1 & 0 & 1 \\
\hline 66 & $\begin{array}{l}\text { (80 massive endoskeletal head shield } \\
\text { covering gills dorsally) }\end{array}$ & 0.333 & 0.667 & 0.333 & 1 & 0 & 1 \\
\hline 67 & (81 sclerotic ossicles) & 0.5 & 0.5 & 0.667 & 0.5 & 0.5 & 0.667 \\
\hline 68 & (82 ossified scleral capsule) & 0.5 & 0.5 & 0.5 & 0.333 & 0.667 & \\
\hline
\end{tabular}

